\title{
Water Quality in the Bear River Basin of Utah, Idaho, and Wyoming Prior to and Following Snowmelt Runoff in 2001
}

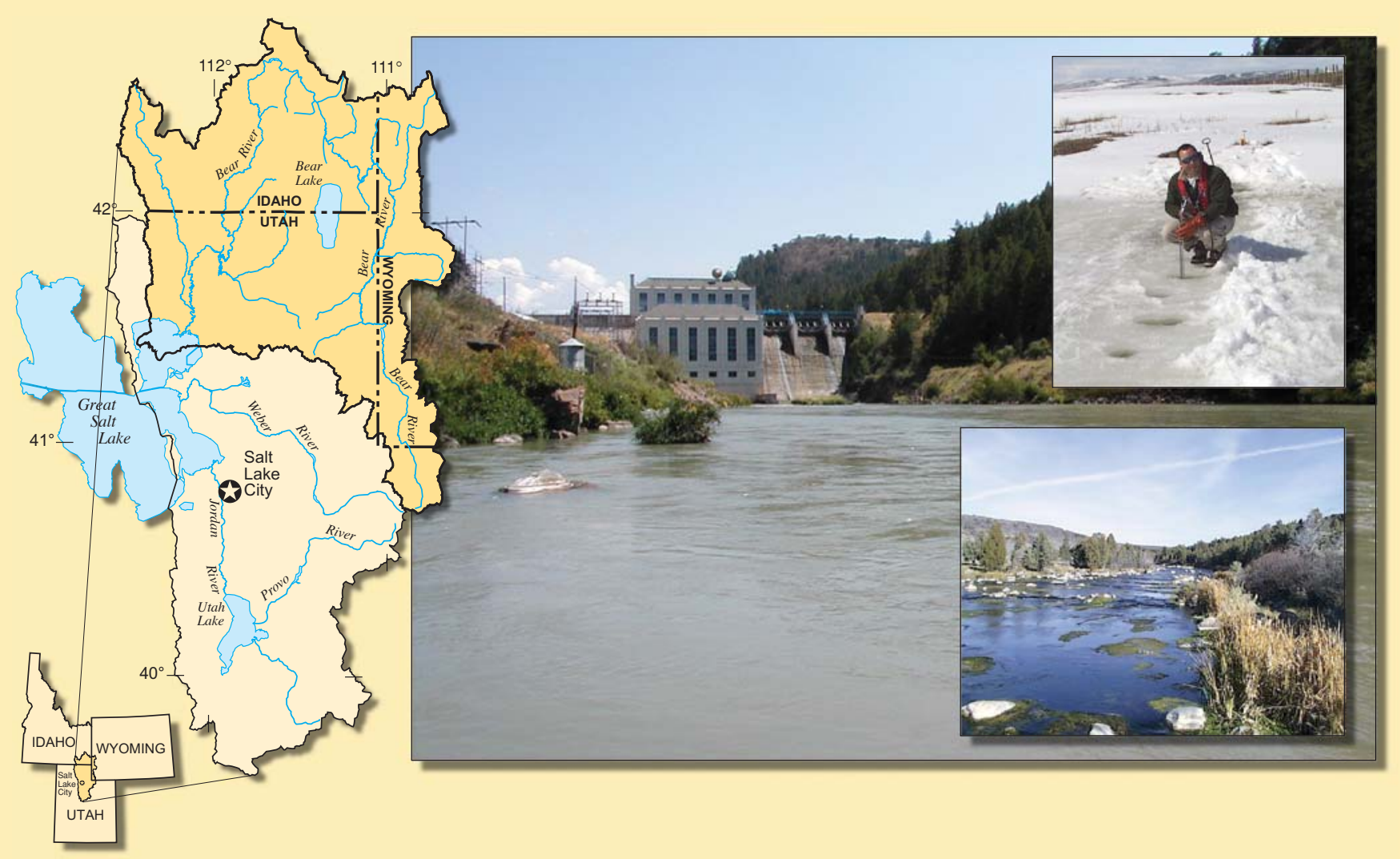

Scientific Investigations Report 2006-5292

U.S. Department of the Interior

U.S. Geological Survey

NATIONAL WATER-QUALITY ASSESSMENT PROGRAM 


\section{Cover photos:}

Background-Soda Dam and hydroelectric plant on the Bear River near Soda Springs, Idaho.

Foreground (Upper)—Water-quality sampling on the Bear River, March 2001.

Foreground (Lower)-The Bear River in Black Canyon near Grace, Idaho.

(Photographs by Jay Cederberg, U.S. Geological Survey) 


\section{Water Quality in the Bear River Basin of Utah, Idaho, and Wyoming Prior to and Following Snowmelt Runoff in 2001}

By Steven J. Gerner and Lawrence E. Spangler

Scientific Investigations Report 2006-5292

NATIONAL WATER-QUALITY ASSESSMENT PROGRAM 


\title{
U.S. Department of the Interior \\ DIRK KEMPTHORNE, Secretary
}

\author{
U.S. Geological Survey \\ Mark D. Meyer, Director
}

U.S. Geological Survey, Reston, Virginia: 2006

For product and ordering information:

World Wide Web: http://www.usgs.gov/pubprod

Telephone: 1-888-ASK-USGS

For more information on the USGS--the Federal source for science about the Earth, its natural and living resources, natural hazards, and the environment:

World Wide Web: http://www.usgs.gov

Telephone: 1-888-ASK-USGS

Any use of trade, product, or firm names is for descriptive purposes only and does not imply endorsement by the U.S. Government.

Although this report is in the public domain, permission must be secured from the individual copyright owners to reproduce any copyrighted materials contained within this report. 


\section{FOREWORD}

The U.S. Geological Survey (USGS) is committed to serve the Nation with accurate and timely scientific information that helps enhance and protect the overall quality of life, and facilitates effective management of water, biological, energy, and mineral resources (http:// www.usgs.gov/). Information on the quality of the Nation's water resources is of critical interest to the USGS because it is so integrally linked to the long-term availability of water that is clean and safe for drinking and recreation and that is suitable for industry, irrigation, and habitat for fish and wildlife. Escalating population growth and increasing demands for the multiple water uses make water availability, now measured in terms of quantity and quality, even more critical to the long-term sustainability of our communities and ecosystems.

The USGS implemented the National Water-Quality Assessment (NAWQA) program to support national, regional, and local information needs and decisions related to water-quality management and policy (http://water.usgs.gov/nawqa). Shaped by and coordinated with ongoing efforts of other Federal, State, and local agencies, the NAWQA program is designed to answer: What is the condition of our Nation's streams and ground water? How are the conditions changing over time? How do natural features and human activities affect the quality of streams and ground water, and where are those effects most pronounced? By combining information on water chemistry, physical characteristics, stream habitat, and aquatic life, the NAWQA program aims to provide science-based insights for current and emerging water issues and priorities. NAWQA results can contribute to informed decisions that result in practical and effective water-resource management and strategies that protect and restore water quality.

Since 1991, the NAWQA program has implemented interdisciplinary assessments in more than 50 of the Nation's most important river basins and aquifers, referred to as Study Units (http://water.usgs.gov/nawqa/ nawqamap.html). Collectively, these Study Units account for more than 60 percent of the overall water use and population served by public water supply, and are representative of the Nation's major hydrologic landscapes, priority ecological resources, and agricultural, urban, and natural sources of contamination.

Each assessment is guided by a nationally consistent study design and methods of sampling and analysis. The assessments thereby build local knowledge about water-quality issues and trends in a particular stream or aquifer while providing an understanding of how and why water quality varies regionally and nationally. The consistent, multi-scale approach helps to determine if certain types of water-quality issues are isolated or pervasive, and allows direct comparisons of how human activities and natural processes affect water quality and ecological health in the Nation's diverse geographic and environmental settings. Comprehensive assessments on pesticides, nutrients, volatile organic compounds, trace metals, and aquatic ecology are developed at the national scale through comparative analysis of the Study-Unit findings (http://water.usgs.gov/nawqa/natsyn.html).

The USGS places high value on the communication and dissemination of credible, timely, and relevant science so that the most recent and available knowledge about water resources can be applied in management and policy decisions. We hope this NAWQA publication will provide you the needed insights and information to meet your needs, and thereby foster increased awareness and involvement in the protection and restoration of our Nation's waters.

The NAWQA program recognizes that a national assessment by a single program cannot address all water- resource issues of interest. External coordination at all levels is critical for a fully integrated understanding of watersheds and for cost-effective management, regulation, and 
conservation of our Nation's water resources. The program, therefore, depends extensively on the advice, cooperation, and information from other Federal, State, interstate, Tribal, and local agencies, non-government organizations, industry, academia, and other stakeholder groups. The assistance and suggestions of all are greatly appreciated.

\section{Robest m. firch}

Robert M. Hirsch

Associate Director for Water 


\section{Contents}

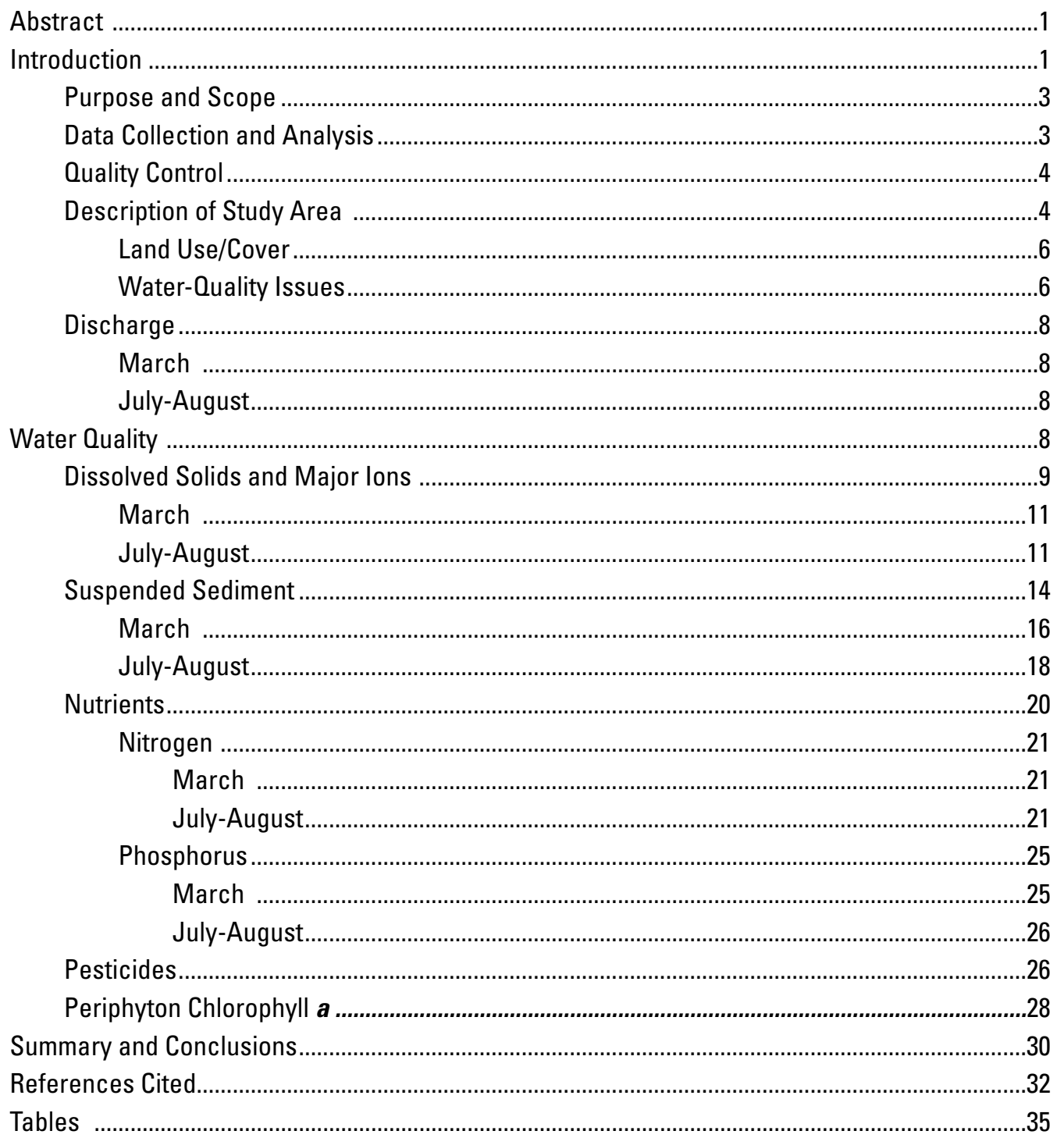




\section{Figures}

1. Location of sites sampled in the Bear River basin, Utah, Idaho, and Wyoming, March and July-August 2001.

2. Relation of dissolved to total nitrite plus nitrate (as N) for selected sites in the Bear River basin, March 2001.....................................................................................

3. Diversion network for regulation of the Bear River at Bear Lake, Idaho ...........................5

4. Land use/cover in the Bear River basin upstream from Corinne, Utah .............................7

5. Instantaneous and daily mean discharge at gaged sites on the Bear River, (A)

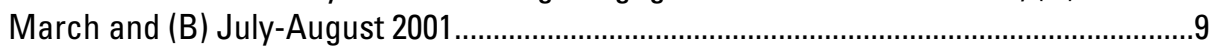

6. Discharge at Bear River sites 18 and 48, (A) March and (B) July-August 2001 ...............10

7. Chemical composition of water samples collected from selected main-stem sites in the Bear River basin, March and July-August 2001

8. Concentration of dissolved solids in water samples collected from selected sites in the Bear River basin, March 2001

9. Dissolved-solids load calculated from water samples collected from selected sites in the Bear River basin, March 2001.

10. Concentration of dissolved solids in water samples collected from selected sites in the Bear River basin, July-August 2001

11. Dissolved-solids load calculated from water samples collected from selected sites in the Bear River basin, July-August 2001

12. Concentration of suspended sediment in water samples collected from selected sites in the Bear River basin, March 2001

13. Suspended-sediment load calculated from water samples collected from selected sites in the Bear River basin, March 2001

14. Concentration of suspended sediment in water samples collected from selected sites in the Bear River basin, July-August 2001

15. Suspended-sediment load calculated from water samples collected from selected sites in the Bear River basin, July-August 2001

16. Concentration of dissolved nitrite plus nitrate in water samples collected from selected sites in the Bear River basin, March 2001

17. Dissolved nitrite plus nitrate load calculated from water samples collected from selected sites in the Bear River basin, March 2001.

18. Concentration of dissolved nitrite plus nitrate in water samples collected from selected sites in the Bear River basin, July-August 2001.

19. Dissolved nitrite plus nitrate load calculated from water samples collected from selected sites in the Bear River basin, July-August 2001.

20. Concentration of total phosphorus in water samples collected from selected sites in the Bear River basin, March 2001.

21. Total phosphorus load calculated from water samples collected from selected sites in the Bear River basin, March 2001.

22. Concentration of total phosphorus in water samples collected from selected sites in the Bear River basin, July-August 2001

23. Total phosphorus load calculated from water samples collected from selected sites in the Bear River basin, July-August 2001

24. Concentration of chlorophyll $a$ in periphyton (algae) samples collected from selected sites in the Bear River basin, August 2001 


\section{Tables}

1. Location of sites sampled on the Bear River and its tributaries, March and July-August 2001.

2. Drainage area and land use/cover in the Bear River basin above sites sampled on the Bear River, March and July-August 2001

3. List of impaired water bodies in the Bear River basin, 2004-05 .

4. Water bodies in the Bear River basin with associated Total Maximum Daily Load (TMDL) documents

5. Discharge, dissolved-oxygen concentration, and physical properties for water samples collected from selected sites on the Bear River and its tributaries, March and July-August 2001.

6. Statistical summary of discharge, and concentrations of dissolved solids, suspended sediment, and nutrients for water samples collected from streams in the Bear River basin, March 2001

7. Statistical summary of discharge, and concentrations of dissolved solids, suspended sediment, and nutrients for water samples collected from streams in the Bear River basin, July-August 2001.

8. Yield of nutrients, dissolved solids, and suspended sediment from Bear River tributary basins, March and July-August 2001

9. Results of chemical analyses for water samples collected from selected sites on the Bear River and its tributaries, March and July-August 2001.

10. Results of nutrient and sediment analyses for water samples collected from selected sites on the Bear River and its tributaries, March and July-August 2001

11. Pesticides detected in water samples collected from selected sites in the Bear River basin, March and July-August 2001.

12. Results of pesticide analyses of water samples collected from selected sites on the Bear River and its tributaries, March and July-August 2001.

13. Concentration of chlorophyll $a$ in periphyton (algae) samples collected from selected sites in the Bear River basin, August 2001 


\section{Conversion Factors, Datums, and Abbreviated Water-Quality Units}

\begin{tabular}{lcl}
\hline \multicolumn{1}{c}{ Multiply } & \multicolumn{1}{c}{ By } & \multicolumn{1}{c}{ To obtain } \\
\hline acre-foot (acre-ft) & 1,233 & cubic meter $\left(\mathrm{m}^{3}\right)$ \\
acre-foot per year (acre-ft/yr) & 1,233 & cubic meter per year $\left(\mathrm{m}^{3} / \mathrm{yr}\right)$ \\
cubic foot per second $\left(\mathrm{ft}^{3} / \mathrm{s}\right)$ & 0.02832 & cubic meter per second $\left(\mathrm{m}^{3} / \mathrm{s}\right)$ \\
foot (ft) & 0.3048 & meter $(\mathrm{m})$ \\
pound per acre per day $(\mathrm{lb} / \mathrm{acre} / \mathrm{d})$ & 0.1836 & kilogram per square hectometer per \\
& & day $\left(\mathrm{kg} / \mathrm{hm}^{2} / \mathrm{d}\right)$ \\
mile (mi) & 1.609 & kilometer $(\mathrm{km})$ \\
square mile $\left(\mathrm{mi}^{2}\right)$ & 2.590 & square $\mathrm{kilometer}\left(\mathrm{km}^{2}\right)$ \\
ton per day $(\operatorname{ton} / \mathrm{d})$ & 0.9072 & metric ton per day $(\mathrm{mton} / \mathrm{d})$ \\
\hline
\end{tabular}

Temperature in degrees Celsius $\left({ }^{\circ} \mathrm{C}\right)$ may be converted to degrees Fahrenheit $\left({ }^{\circ} \mathrm{F}\right)$ as follows:

$$
{ }^{\circ} \mathrm{F}=\left(1.8 \times{ }^{\circ} \mathrm{C}\right)+32 .
$$

Horizontal coordinate information is referenced to the North American Datum of 1983 (NAD 83). Vertical coordinate information is referenced to the North American Vertical Datum of 1988 (NAVD 88). Altitude, as used in this report, refers to distance above the vertical datum.

Specific conductance is reported in microsiemens per centimeter at 25 degrees Celsius $\left(\mu \mathrm{S} / \mathrm{cm}\right.$ at $\left.25^{\circ} \mathrm{C}\right)$.

Concentrations of chemical constituents in water are reported either in milligrams per liter $(\mathrm{mg} / \mathrm{L})$ or micrograms per liter $(\mu \mathrm{g} / \mathrm{L})$. Concentrations of periphyton chlorophyll $a$ are reported in milligrams per square meter $\left(\mathrm{mg} / \mathrm{m}^{2}\right)$. 


\title{
Water Quality in the Bear River Basin of Utah, Idaho, and Wyoming Prior to and Following Snowmelt Runoff in 2001
}

\author{
By Steven J. Gerner and Lawrence E. Spangler
}

\section{Abstract}

Water-quality samples were collected from the Bear River during two base-flow periods in 2001: March 11 to 21, prior to snowmelt runoff, and July 30 to August 9 , following snowmelt runoff. The samples were collected from 65 sites along the Bear River and selected tributaries and analyzed for dissolved solids and major ions, suspended sediment, nutrients, pesticides, and periphyton chlorophyll $a$.

On the main stem of the Bear River during March, dissolved-solids concentrations ranged from 116 milligrams per liter (mg/L) near the Utah-Wyoming Stateline to $672 \mathrm{mg} / \mathrm{L}$ near Corinne, Utah. During July-August, dissolved-solid concentrations ranged from $117 \mathrm{mg} / \mathrm{L}$ near the Utah-Wyoming Stateline to $2,540 \mathrm{mg} / \mathrm{L}$ near Corinne and were heavily influenced by outflow from irrigation diversions. High concentrations of dissolved solids near Corinne result largely from inflow of mineralized spring water.

Suspended-sediment concentrations in the Bear River in March ranged from 2 to $98 \mathrm{mg} / \mathrm{L}$ and generally decreased below reservoirs. Tributary concentrations were much higher, as high as $861 \mathrm{mg} / \mathrm{L}$ in water from Battle Creek. Streams with high sediment concentrations in March included Whiskey Creek, Otter Creek, and the Malad River. Sediment concentrations in tributaries in July-August generally were lower than in March.

The concentrations of most dissolved and suspended forms of nitrogen generally were higher in March than in JulyAugust. Dissolved ammonia concentrations in the Bear River and its tributaries in March ranged from less than $0.021 \mathrm{mg} / \mathrm{L}$ to as much as $1.43 \mathrm{mg} / \mathrm{L}$, and dissolved ammonia plus organic nitrogen concentrations ranged from less than $0.1 \mathrm{mg} / \mathrm{L}$ to $2.4 \mathrm{mg} / \mathrm{L}$. Spring Creek is the only site where the concentrations of all ammonia species exceeded $1.0 \mathrm{mg} / \mathrm{L}$. In samples collected during March, tributary concentrations of dissolved nitrite plus nitrate ranged from $0.042 \mathrm{mg} / \mathrm{L}$ to $5.28 \mathrm{mg} / \mathrm{L}$. In samples collected from tributaries during July-August, concentrations ranged from less than $0.23 \mathrm{mg} / \mathrm{L}$ to $3.06 \mathrm{mg} / \mathrm{L}$. Concentrations of nitrite plus nitrate were highest in samples collected from the Whiskey Creek and Spring Creek drainage basins and from main-stem sites below Cutler Reservoir near Collinston (March) and Corinne (July-August).

Concentrations of total phosphorus at main-stem sites were fairly similar during both base-flow periods, ranging from less than 0.02 to $0.49 \mathrm{mg} / \mathrm{L}$ during March and less than 0.02 to $0.287 \mathrm{mg} / \mathrm{L}$ during July-August. In March, concentra- tions of total phosphorus in the Bear River generally increased from upstream to downstream. Total phosphorus concentrations in tributaries generally were higher in March than in July-August.

Concentrations of selected pesticides in samples collected from 20 sites in the Bear River basin in either March or July-August were less than 0.1 microgram per liter. Of the 12 pesticides detected, the most frequently detected insecticide was malathion, and prometon and atrazine were the most frequently detected herbicides.

Periphyton samples were collected at 14 sites on the Bear River during August. Chlorophyll $a$ concentrations ranged from 21 milligrams per square meter $\left(\mathrm{mg} / \mathrm{m}^{2}\right)$ to $416 \mathrm{mg} / \mathrm{m}^{2}$, with highest concentrations occurring below reservoirs. Samples from 8 of the 14 sites had concentrations of chlorophyll $a$ that exceeded $100 \mathrm{mg} / \mathrm{m}^{2}$, indicating that algal abundance at these sites may represent a nuisance condition.

\section{Introduction}

The National Water-Quality Assessment (NAWQA) program began full-scale implementation in 1991. The objectives of the NAWQA program are to describe the status of, and trends in, the quality of the Nation's ground-water and surfacewater resources, as well as to develop an understanding of the natural and human factors affecting these resources (Gilliom and others, 1995). The Great Salt Lake Basins (GRSL) study unit is 1 of 51 study units that are included in this national program. Water-quality investigations began in the first group of 20 study units in 1991. A second group of 16 study units began investigations in 1994, and a third group of 15 study units, including the GRSL, began in 1997.

Water-quality assessments within the GRSL have included studies by Baskin and others (2002), Gerner (2003), Waddell and Giddings (2003), and Waddell and others (2004). This synoptic study is a component of the NAWQA surfacewater study design used to assess the spatial distribution of selected constituent groups along the Bear River and its tributaries over a limited time period. In 2001, water-quality samples were collected at 65 sites (fig. 1, table 1) on the Bear River and selected tributaries, which were distributed from near the Utah-Wyoming Stateline south of Evanston, Wyoming, downstream to Corinne, Utah. Samples were analyzed for dissolved solids and major ions, suspended sediment, nutrients, pesticides, and periphyton chlorophyll $a$ (CHL A). 


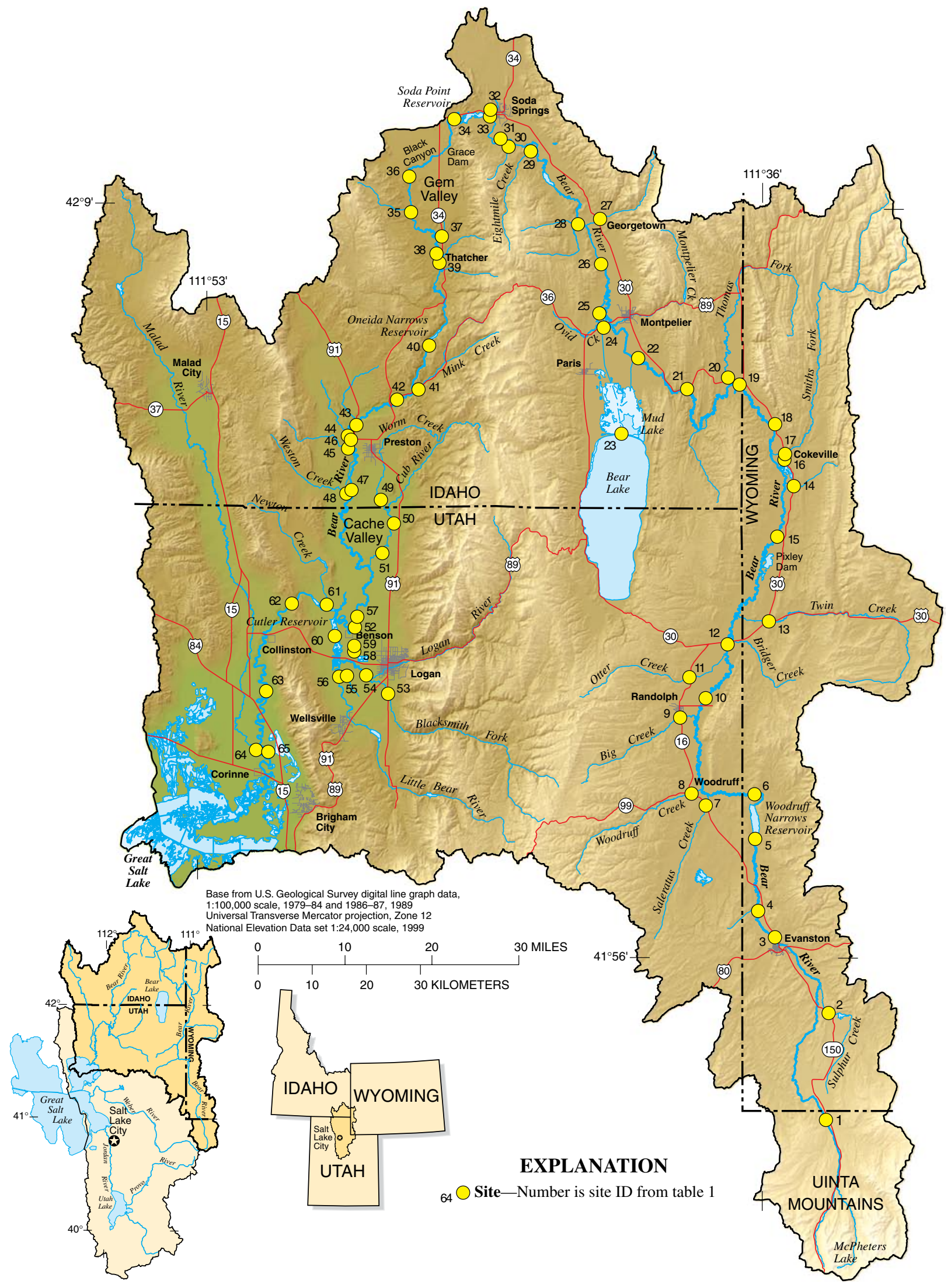

Figure 1. Location of sites sampled in the Bear River basin, Utah, Idaho, and Wyoming, March and July-August 2001. 
The Bear River is used extensively for irrigation and power generation and has the potential to provide additional drinking water to the growing population in the GRSL. Many groups, both public and private, are interested in the quality of water in the Bear River. This study was designed to help define the spatial variation in water quality in the Bear River basin during two natural base-flow periods in 2001: in March, prior to snowmelt runoff, and in July-August, following snowmelt runoff. The July-August period coincides with the irrigation season in the Bear River basin. The water quality at baseflow conditions in many segments of the river was affected by releases of stored water and by irrigation withdrawals. This study provides additional information on selected water-quality parameters to assist managers in evaluating the effects of adjoining areas on the quality of water in the Bear River.

\section{Purpose and Scope}

This report describes the quality of water in the Bear River and selected tributaries as it relates to dissolved solids and major ions, suspended sediment, nutrients, pesticides, and CHL A during two natural base-flow periods prior to (March) and following (July-August) snowmelt runoff in 2001. Concentrations and loads of dissolved solids, suspended sediment, and nutrients are compared among sites and between the two study periods. Concentrations of nutrients and CHL A are compared to guidelines that indicate the existence of, or potential for, eutrophication.

\section{Data Collection and Analysis}

In 2001, samples were collected at 57 sites on the Bear River and selected tributaries from March 11 through 21, and at 63 sites from July 30 through August 9. Limited resources, coupled with the complexity of sampling protocols, necessitated that samples be collected over a period of many days for both of the sampling periods. Site visits generally occurred in an upstream direction. Water samples were collected at each site according to field procedures outlined in Shelton (1994) and Horowitz and others (1994). These samples were processed in the field immediately after collection to reduce the possibility of chemical or biological alteration. Samples were analyzed for major ions, nutrients, and pesticides at either the U.S. Geological Survey (USGS) National Water Quality Laboratory (NWQL) in Denver, Colorado, or the Utah State Health Laboratory in Salt Lake City, Utah. Algae samples were collected by using methods outlined in Porter and others (1993). These samples were analyzed for CHL A by fluorometry at the USGS Utah Water Science Center laboratory and by high-pressure liquid chromatography (HPLC) at the NWQL. Samples were analyzed for suspended sediment at the Cascades Volcano Observatory Sediment Laboratory in Vancouver, Washington.

In this report, the term "dissolved" refers to that portion of a sample that has passed through a 0.70-micron filter (pes- ticides only) or a 0.45 -micron filter (all other constituents). Dissolved-solids concentrations in this report refer to analyses of sample residue on evaporation at $180^{\circ} \mathrm{C}$. Concentrations of total nitrogen were calculated by adding measured concentrations of total Kjeldahl nitrogen (total ammonia plus organic nitrogen) and total nitrite plus nitrate. Samples collected in March were analyzed for dissolved nitrite plus nitrate at the NWQL, and for total nitrite plus nitrate at the Utah State Health Laboratory. Measured values from sites that had both analyses were used to develop a linear regression model (fig. 2) that was used to estimate dissolved nitrite plus nitrate concentration at tributary sites where only total nitrite plus nitrate concentration was measured. On the basis of the regression, about 96 percent of the total nitrogen is dissolved. The estimated values for dissolved nitrite plus nitrate concentration were used in the computation of summary statistics and graphics for the March sampling period at 18 tributary sites.

To compare constituent concentrations among sites, quartiles $\left(25^{\text {th }}\right.$ percentile, $50^{\text {th }}$ percentile or median, and $75^{\text {th }}$ percentile) were calculated for each constituent group. These quartiles were then used to divide the samples into groups: "low" for the group below the $25^{\text {th }}$ percentile, "moderately low" for the group between the $25^{\text {th }}$ percentile and the median $\left(50^{\text {th }}\right.$ percentile), "moderately high" for the group between the median and the $75^{\text {th }}$ percentile, and "high" for the group above the $75^{\text {th }}$ percentile. These groupings are color-coded and graphically illustrated to allow the reader to quickly detect differences in concentrations among sites. This method, however, has limited usefulness for comparing concentrations between sampling periods at individual sites without close inspection of the quartile boundaries for each grouping.

Constituents that are detected at concentrations between the Long-Term Method Detection Level (LT-MDL) and Minimum Reporting Level (MRL) are reported as "estimated."

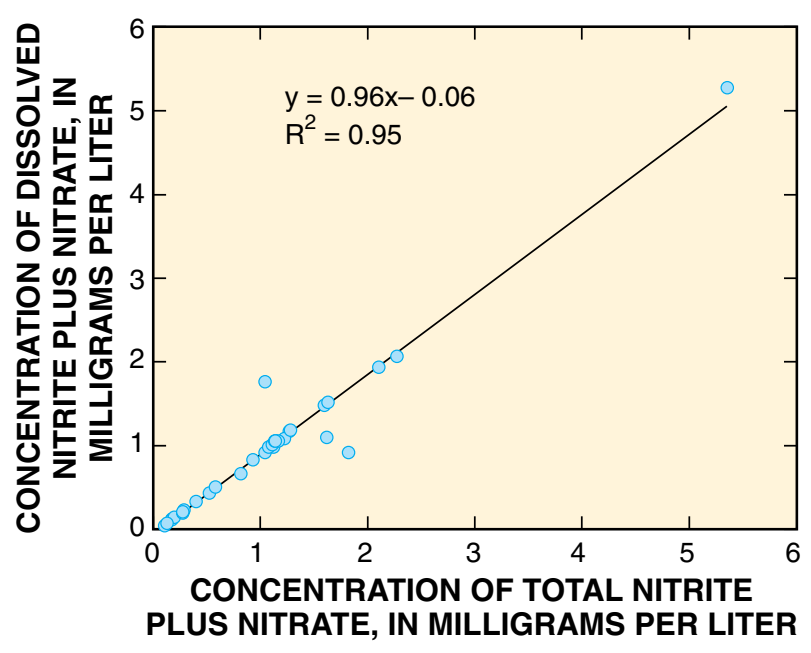

Figure 2. Relation of dissolved to total nitrite plus nitrate (as N) for selected sites in the Bear River basin, March 2001. 
The LT-MDL controls false positive errors so that the chance of falsely reporting a concentration at or greater than the LTMDL for a sample that did not contain the analyte is predicted to be less than or equal to 1 percent. Estimated concentrations are noted with a remark code of "e." These data should be used with the understanding that their uncertainty is greater than that of data reported without the "e" remark code. If an analytical method consistently results in poor recovery or high variability of an analyte, the "e" remark code may be assigned to measured concentrations of that analyte. Concentrations with the " $\mathrm{e}$ " remark code were considered as detections in the data analysis and were included in the statistical analysis.

\section{Quality Control}

Quality-control samples were collected at select sites to determine if data quality associated with water samples collected for this study is sufficient for water-quality assessments. Three types of quality-control samples were collected and analyzed: (1) field blanks to determine sample bias, (2) replicates to determine sample variability, and (3) field-matrix spikes to test for bias from sample matrix interference.

Nine field blank samples were collected at selected waterquality monitoring sites during this study. Of these, three were analyzed for major ions, five were analyzed for nutrients, and three were analyzed for pesticides. No constituents were detected above the laboratory method reporting limits (MRLs). There were detections of dissolved ammonia and dissolved nitrite plus nitrate that were between the MRL and the method detection limit (MDL). Values between the MRL and MDL are always qualified as estimated; however, the detection of ammonia and dissolved nitrite plus nitrate in concentrations between the MRL and MDL (approximately 0.02 to $0.04 \mathrm{mg}$ / $\mathrm{L}$ ) indicates the possibility of a small positive bias, and values in this range should be interpreted with caution.

Ten replicate samples were collected at selected waterquality monitoring sites during this study. Of these, three were analyzed for major ions, five were analyzed for nutrients, and two were analyzed for pesticides. For the replicate major-ion samples, the average relative standard deviation (RSD) for all constituents except fluoride was less than 2 percent, which indicates that variability due to sample collection and processing or lab analytical procedures was small. The average RSD among fluoride samples was 14 percent; however, absolute differences between samples were $0.1 \mathrm{mg} / \mathrm{L}$ or less. The variability associated with collection, processing, and laboratory analysis of water samples for nutrients was larger in some cases. For example, the average RSD was 20 percent for dissolved phosphorus samples, 8.2 percent for ammonia samples, and 4.7 percent for total phosphorus samples. All of the other nutrient species for which replicate samples were analyzed had RSDs of less than 3 percent. Comparison of results for dissolved phosphorus and ammonia concentrations between sites should be made with caution, particularly when the values are small or of relatively equal magnitude.
Surrogate compounds that were expected to perform similarly to some of the pesticide analytes were added to all of the pesticide samples. Recovery of these surrogates ranged from 72.8 to 134 percent and averaged 99.2 percent, indicating that sample-matrix effects and gross sample-processing errors probably did not affect most analytical results for pesticides. Replicate pesticide samples collected at two sites during August were spiked with known concentrations of specific analytes. These field-matrix-spike samples test for bias from matrix interference and analyte degradation. The recovery of 36 analytes in the two samples ranged from 52 to 189 percent and averaged 114 percent. These data indicate that for the analytes tested, the probability of false negatives is low.

Overall, the data from quality-control samples collected during this study show that for most constituents, bias from sample contamination is minimal or nonexistent, and the sampling and analytical procedures yield reproducible results.

\section{Description of Study Area}

The Bear River has the distinction of being the longest river in North America not draining into an ocean. The Bear River begins and ends in Utah; however, it crosses the border of Utah, Idaho, and Wyoming multiple times on its 500-mi journey from its source in the Uinta Mountains of northeastern Utah to its terminus at Great Salt Lake, only about $90 \mathrm{mi}$ apart (fig. 1). Beginning about 140,000 years ago, eruption of basaltic lava near Soda Springs, Idaho, blocked the Bear River channel and diverted the river from its northwesterly course into the Snake River drainage and on to the Pacific Ocean, south into the Lake Bonneville part of the Great Basin (Bouchard and others, 1998).

The Bear River discharges, on average, about 1.85 million acre-ft/yr (1931-76) to Great Salt Lake (Waddell and Barton, 1980). For the 2001 water year (October 1, 2000, to September 30, 2001), total discharge of the Bear River at Corrine, Utah, was about 450,000 acre-ft (Herbert and others, 2002). Discharge from the Bear River is about 62 percent of the total average annual runoff of surface water entering Great Salt Lake.

The Bear River is diverted into Bear Lake at Stewart Dam, near Montpelier, Idaho (fig. 3). Naturally isolated from each other for thousands of years, a connection between the Bear River and Bear Lake was established during 1911-12 so that the lake could be used as a water-storage reservoir (Utah Power and Light, written commun., 2006). The Rainbow Canal transports water from the diversion into Mud Lake, a shallow lake separated from Bear Lake by a natural dike. This water then can be either diverted into Bear Lake or returned to the Bear River through a canal that connects Mud Lake with the Bear Lake Outlet Canal (fig. 3). Water from Bear Lake can be pumped by the Lifton pumping station through the outlet canal and into the Bear River. When full, the surface area of Bear Lake is about $140 \mathrm{mi}^{2}$, and the maximum depth exceeds $200 \mathrm{ft}$. Consequently, Bear Lake is capable of storing about 


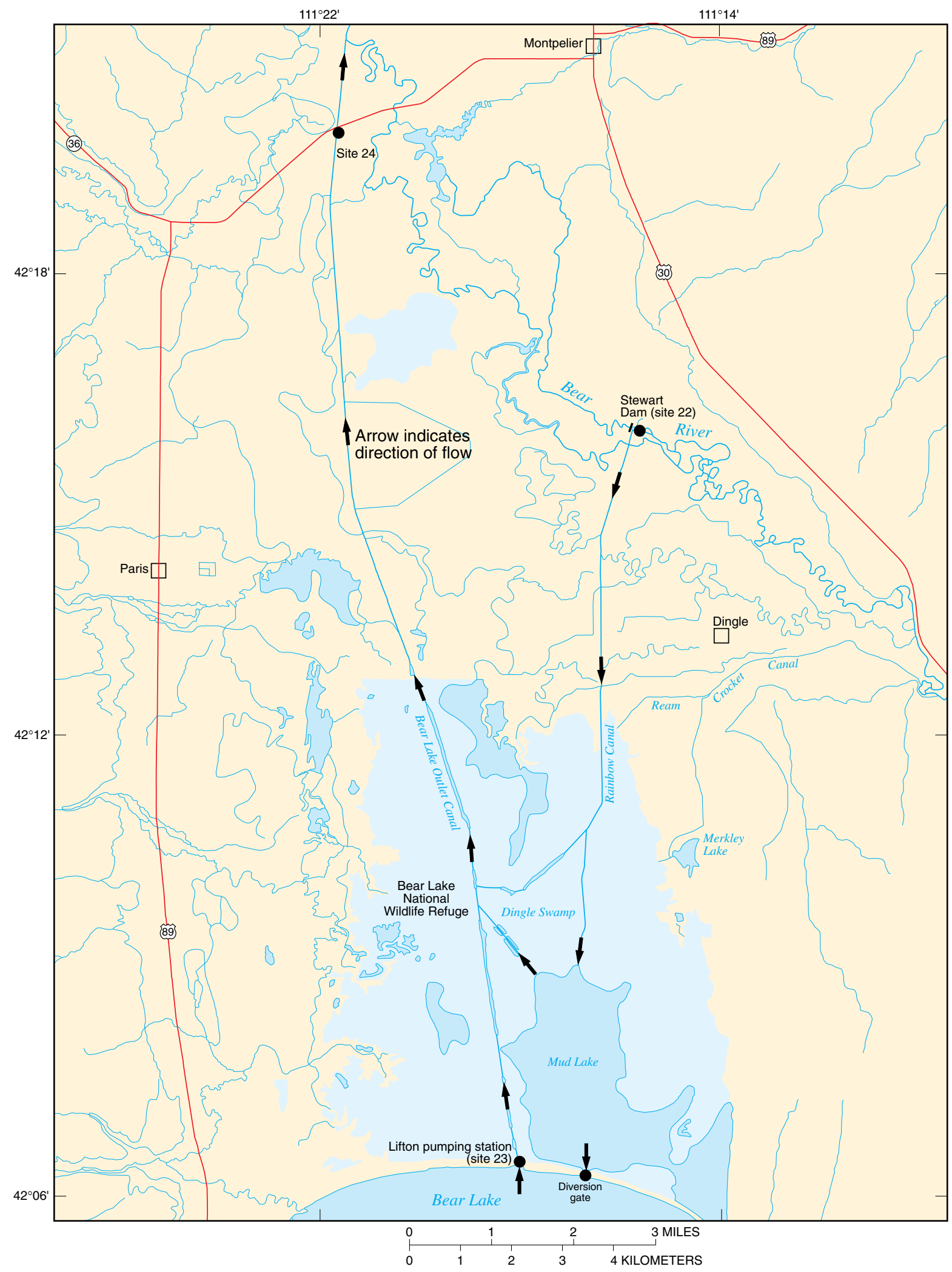

Figure 3. Diversion network for regulation of the Bear River at Bear Lake, Idaho. 
$1,420,000$ acre-ft of water, making it the largest reservoir in the Bear River system. Historically, the level of the lake was maintained by inflow from springs and surface runoff of rain and snow.

During 1995, irrigation for agriculture accounted for an estimated 92 percent of all water use in the Bear River drainage, and public supply accounted for an estimated 4 percent of all water use (Baskin and others, 2002). A network of dams, reservoirs, and diversion structures regulates flow in the Bear River for irrigation and hydroelectric-power generation and modifies the natural hydrologic variability of the river and the physical, chemical, and biological conditions in the river. Flow modification from dams and reservoirs also affects streambank stability and sediment concentration.

\section{Land Use/Cover}

Knowledge of land use and land cover can enhance our understanding of natural and anthropogenic factors that influence water quality. Rangeland is the most common land cover upstream from all but two sites on the Bear River and ranges from about 26 to 75 percent of total land cover (fig. 4 and table 2). Forest is the principal land cover (about 45 to 67 percent) upstream from Evanston, Wyoming (figs. 1 and 4; table 2), but makes up only 14 to 19 percent of the watershed downstream from Randolph, Utah. Concentrations of contaminants in streams generally increase with increasing amounts of agricultural and urban land in a watershed, largely because of increases in the amount of chemicals used and less water being available from undeveloped lands to dilute those chemicals. Agricultural land cover ranges from less than 1 to 18 percent of total land cover (fig. 4 and table 2), with percentages of agricultural land generally increasing with distance downstream from Bear Lake. Extensive agricultural areas exist in Gem Valley, Idaho, and Cache Valley, Utah, and in the valley areas below Cutler Reservoir (figs. 1 and 4). Although urban areas cover less than 1 percent of total land cover (fig. 4), they can be a major cause of stream impairment (Paul and Meyer, 2001).

Land-use/cover data were derived from the National Land Cover Dataset (NLCD) (Multi-Resolution Land Characteristics Consortium, 1992). This data set provides a consistent land-cover data layer for the conterminous United States, based on 30-meter Landsat thematic map data, and represents conditions in the early to mid-1990s. For this report, the NLCD land-use/-cover classifications were aggregated into eight land classes defined in Anderson and others (1976) as Level I categories.

\section{Water-Quality Issues}

Nutrient and sediment loading related to hydrologic modification and agricultural land use are the principal water-quality issues in the Bear River basin. Enrichment of Bear Lake with nutrients and sediment from the Bear River has been an ongoing concern of water managers and water users. Channelization, streamflow modification, and grazing of rangelands contribute to sediment loads in the upper part of the drainage basin. Feedlots, dairy operations, and irrigated crops contribute to nutrient loads in the lower part of the drainage basin. Most tributaries to the Bear River are seasonally diverted for irrigation. Irrigation return flow, with generally higher dissolved-solids concentrations, affects the water quality of the Bear River.

Further insight into problems affecting the quality of streams and reservoirs of the Bear River basin can be obtained from the most recent (2004-05) 303(d) listing of impaired water bodies developed by the States of Utah, Idaho, and Wyoming (Utah Division of Water Quality, 2004; Idaho Department of Environmental Quality, 2005; and Wyoming Department of Environmental Quality, 2004). The Clean Water Act requires that all States develop and update a 303(d) list of water bodies that do not meet their designated beneficial uses and identify the causes of impairment in those water bodies. State 303(d) lists for Utah, Idaho, and Wyoming include 39 stream segments and 7 reservoirs/lakes in the Bear River basin (table 3). Most of the affected stream segments are tributaries to the Bear River. High sediment concentrations and excess nutrient loads are the most frequently identified causes of impairment. Water bodies can be removed from the 303(d) list either through evidence that they meet their designated beneficial use or through the development of a plan, detailed in a Total Maximum Daily Load (TMDL) document that addresses the causes of impairment and steps necessary to remove those impairments. Water bodies that have associated TMDLs are listed in table 4.

As a basis for evaluating water quality in streams, the Utah Department of Administrative Services and the Idaho and Wyoming Department of Environmental Quality have established contaminant standards and guidelines based on those recommended by the U.S. Environmental Protection Agency (EPA). Both numeric and qualitative criteria are used by these agencies to assess stream trophic conditions. For instance, Utah has identified concentrations of $0.05 \mathrm{mg} / \mathrm{L}$ of total phosphorus (as $\mathrm{P}$ ) and $4.0 \mathrm{mg} / \mathrm{L}$ of nitrate (as $\mathrm{N}$ ) as indicators of excessive nutrients (Utah Division of Administrative Rules, 2005). Idaho stipulates that "Surface waters of the state shall be free from excess nutrients that can cause visible slime growths or other nuisance aquatic growths impairing designated beneficial uses," (Idaho Department of Environmental Quality, 2003), and Wyoming stipulates that "Surface waters shall be free from substances and conditions or combinations thereof which are attributable to or influenced by the activities of man, in concentrations which produce undesirable aquatic life" (Wyoming Department of Environmental Quality, 2001).

EPA section 304(a), water-quality criteria for nutrients, provides a starting point for evaluating the effects of high nutrient concentrations on aquatic communities (U.S. Environmental Protection Agency, 2000a). These criteria represent reference conditions, within ecoregions, of surface waters that are minimally impacted by human activities and are protec- 


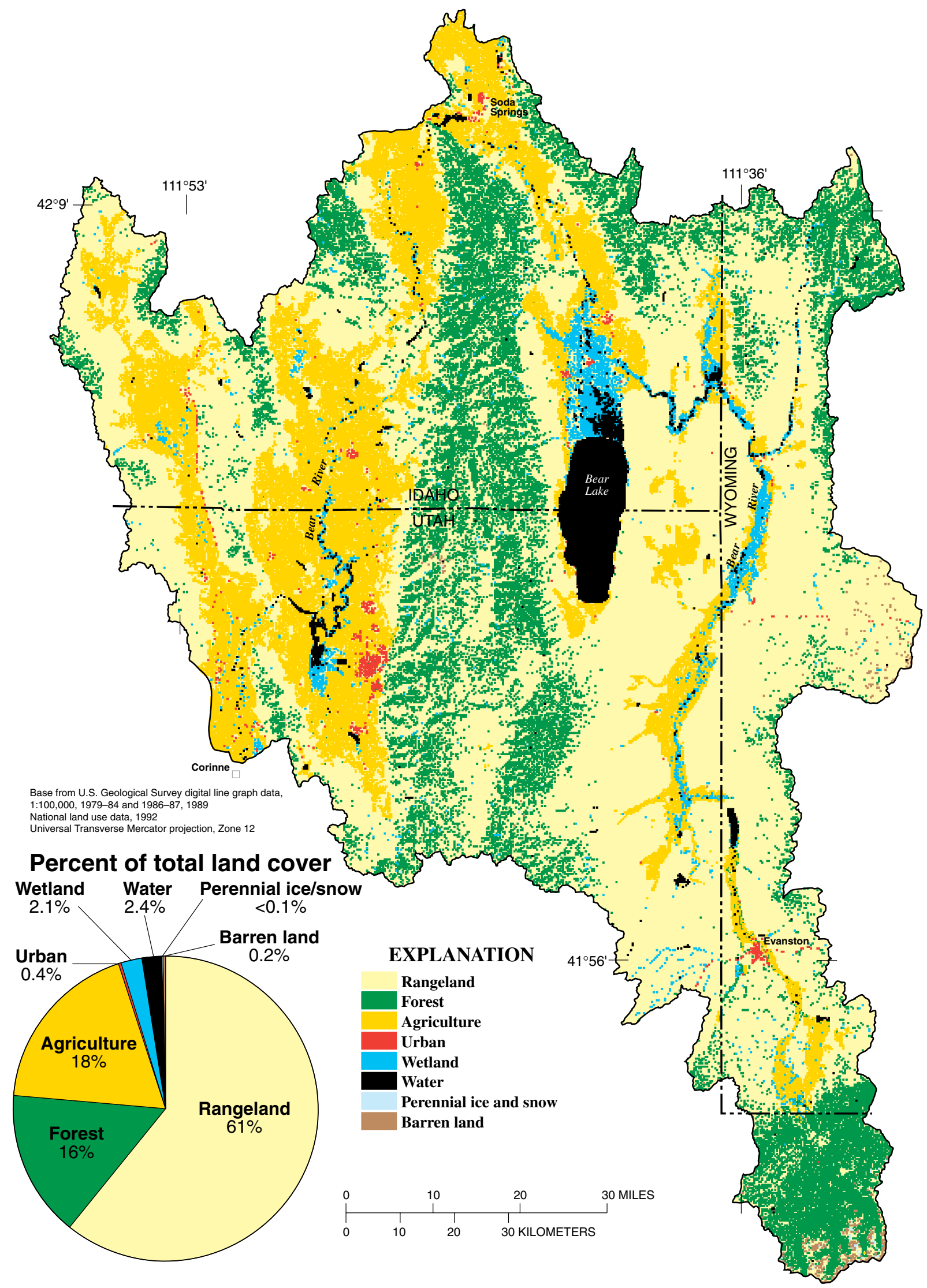

Figure 4. Land use/cover in the Bear River basin upstream from Corinne, Utah. 
tive of aquatic life and recreational uses. Reference conditions have been established by the EPA for each ecoregion (U.S. Environmental Protection Agency, 2000b). Nearly all of the sites sampled in this study are in Aggregate Nutrient Ecoregion III, which includes the Central Basin and Range (13), the Wyoming Basin (18), and the Wasatch and Uinta Mountains (19) subecoregions. For Ecoregion III, the following reference conditions have been proposed for establishing nutrient criteria that are protective of designated beneficial uses: $0.025 \mathrm{mg} / \mathrm{L}$ of dissolved nitrite plus nitrate, $0.377 \mathrm{mg} / \mathrm{L}$ of total nitrogen, $0.022 \mathrm{mg} / \mathrm{L}$ of total phosphorus, and $43.9 \mathrm{mg} / \mathrm{m}^{2}$ of periphyton CHL A (U.S. Environmental Protection Agency, 2000b).

\section{Discharge}

Ideally, synoptic studies are conducted under steady-state conditions and samples are collected simultaneously along the study reach. The Bear River is highly regulated, however, and difficult to sample under near steady-state conditions. Flow conditions varied considerably between study periods and among sites. Further, variations in water quality at a specific site for a given sampling period can occur with changes in discharge. Large changes in discharge occurred at some sites on the Bear River during the July-August sampling period as compared with the March sampling period (fig. 5). As a result, mean daily discharge for the sampling period rather than instantaneous discharge was used to calculate constituent loads for main-stem sites with continuous discharge data. Mean daily discharge for the August 6-8 sampling period was used for sites upstream from Bear Lake and July 30-August 5 for sites downstream from Bear Lake (fig. 5B). Instantaneous discharge at sites sampled during this study is listed in table 5.

\section{March}

Discharge at most sites was less than the historical average for the March 11-21 study period (fig. 6A). In the Bear River, discharge ranged from $7 \mathrm{ft}^{3} / \mathrm{s}$ at site 15 to $1,690 \mathrm{ft}^{3} / \mathrm{s}$ at site 65 (fig. 5A). Prior to and during collection of the March samples, warm weather had melted much of the low- and some of the mid-altitude snow cover in the drainage basin below Soda Point Reservoir (site 34). Runoff to the Bear River and its tributaries resulted in increasing discharge toward the end of the sampling period (fig. 6A). This effect was particularly evident downstream from Bear Lake where increases in discharge were as much as 50 percent. Many of the Bear River and tributary sites upstream from Bear Lake remained ice covered during March sampling and had substantially less inflow from snowmelt.

During March, about $107 \mathrm{ft}^{3} / \mathrm{s}$ of water was diverted from the Bear River and stored in Mud Lake (Herbert and others, 2002); however, no water was being diverted into or released from Bear Lake (fig. 5A). In Gem Valley (fig. 1), nearly the entire flow of the Bear River was diverted (by way of penstocks) to the Grace power plant, about 6 mi downstream from the diversion point, and flow in the intervening reach, which includes Black Canyon, consisted mostly of ground-water inflow. A reduction in discharge at site 36 (Bear River at Black Canyon) is evident on many of the figures contained in this report and generally is the result of this diversion.

\section{July-August}

Daily discharge at sites on the Bear River was highly regulated during the July 30-August 9 study period (fig. 6B). Reservoir releases caused variations in discharge at Bear River sites below Soda Point and Oneida Narrows Reservoirs. Typical fluctuations were as much as $200 \mathrm{ft}^{3} / \mathrm{s}$ or about 20 percent of total flow. The Bear River upstream from Bear Lake generally had below-average daily discharge, ranging from less than $1 \mathrm{ft}^{3} / \mathrm{s}$ at site 5 above Woodruff Narrows Reservoir to about $108 \mathrm{ft}^{3} / \mathrm{s}$ at site 18 (Bear River below Smiths Fork) (fig. 5B). Inflow to Mud Lake through the Rainbow Canal was $4.6 \mathrm{ft}^{3} / \mathrm{s}$ (Herbert and others, 2002), while outflow through the Bear Lake Outlet Canal (site 24) averaged 1,280 ft $\mathrm{ft}^{3} / \mathrm{s}$ (table 5). Because of the large inflow from Bear Lake, discharge in the Bear River between Bear Lake and Cutler Reservoir was near the historic average (mean daily discharge) during this period (fig. 6B). Large diversions into the East and West Hammond canals at Cutler Dam, however, resulted in less-than-average discharge in the Bear River below the reservoir.

\section{Water Quality}

The quality of water in Bear River basin streams differed substantially from March to July-August with respect to nitrogen concentration. The median dissolved ammonia concentration in samples from all streams was more than five times higher in samples collected during March (table 6) than in samples collected during July-August (table 7). Runoff from animal feeding operations in proximity of the streams is a likely source of ammonia. The median concentration of dissolved nitrite plus nitrate was more than 10 times higher and the median concentration of total nitrogen was about 3 times higher in samples collected during March than in samples collected during July-August. Although total phosphorus concentrations at main-stem sites were similar for both sampling periods, the median total phosphorus concentration in tributaries generally was higher in March $(0.182 \mathrm{mg} / \mathrm{L})$ than in July-August $(0.082 \mathrm{mg} / \mathrm{L})$, possibly from increased sediment in tributaries in March. The maximum concentration of dissolved solids in streams of the Bear River basin was much higher in July-August (2,540 mg/L) than in March $(1,080 \mathrm{mg} /$ L); however, the difference in the median concentrations (418 $\mathrm{mg} / \mathrm{L}$ and $335 \mathrm{mg} / \mathrm{L}$, respectively) was considerably less. The median concentrations of suspended sediment in Bear River basin streams were the same $(38 \mathrm{mg} / \mathrm{L})$ for the two periods; however, tributaries had substantially higher concentrations 


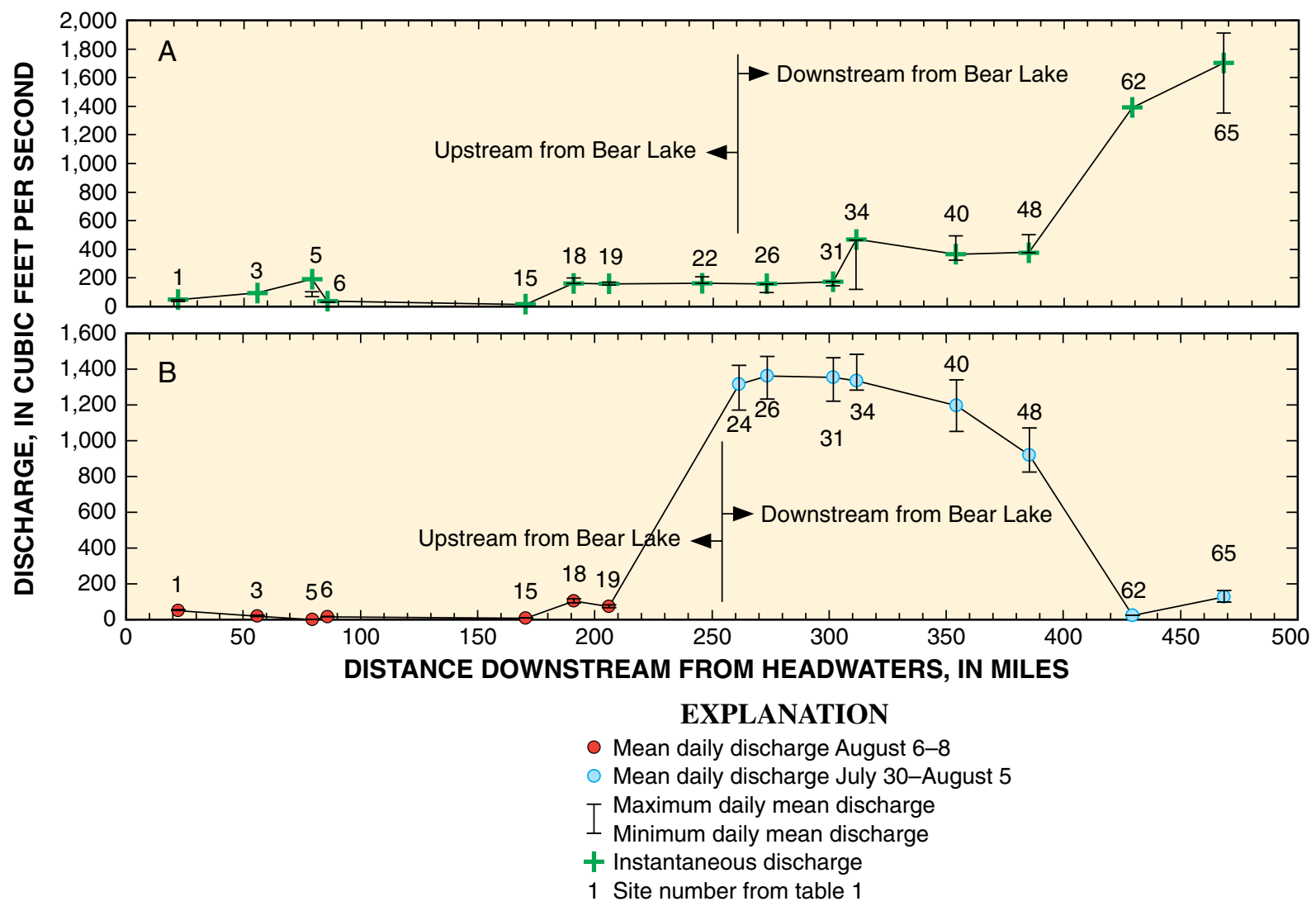

Figure 5. Instantaneous and daily mean discharge at gaged sites on the Bear River, (A) March and (B) July-August 2001.

than main-stem sites in March, while tributaries and mainstem sites had similar concentrations in July-August.

The chemical and sediment load in Bear River basin streams also differed substantially from March to July-August. For instance, the Little Bear River at Benson Marina (site 60) contributed a substantial load of dissolved solids, nutrients, and sediment to the Bear River during March. During JulyAugust, however, discharge was very low and backwater from the Bear River resulted in no detectable flow from the Little Bear River into Cutler Reservoir (and subsequently into the Bear River). Consequently, there was very little contribution of chemical or sediment load to the Bear River from the Little Bear River drainage basin during this time period.

Outflow from point sources, such as wastewater-treatment plants or industrial facilities was not sampled separately, but some stream segments in the Bear River basin are substantially influenced by contaminants from these permitted outflows. Site 58 (fig. 1 ) is on a drainage ditch whose principal source of water is the Logan wastewater-treatment plant; hence, concentrations of dissolved solids and nutrients were substantially elevated at this site. Site 55 (fig. l) is located on Spring Creek, a tributary to the Little Bear River that receives inflow from several facilities that have discharge permits for contaminants.

In addition to providing measurements of constituent concentration, water samples collected at Bear River basin sites were used to calculate constituent yields for some tributary basins (table 8 ). Yields provide a means to compare the relative contribution to stream loads of a parcel of land in a tributary basin. For example, the March suspended-sediment load at site 51 on the Cub River was only slightly higher than that at site 43 on Battle Creek (16.1 and 14.1 tons/d, respectively); however, the yield from the Cub River basin was considerably lower than that from the Battle Creek basin $(0.25$ and $0.70 \mathrm{lbs} /$ acre/d, respectively) (table 8), indicating that the natural and anthropogenic factors contributing to sediment yields in the Battle Creek basin are substantially different from those in the Cub River basin. In addition, sites 37 (Whiskey Creek near Thatcher), 55 (Spring Creek at 600 South), and 58 (Logan waste-water treatment plant ditch) are situated in basins where yields are substantially influenced by pointsource contaminants, and constituent yields for these basins are probably biased high relative to other sites.

\section{Dissolved Solids and Major lons}

Variations in the concentration of dissolved solids and major inorganic constituents in water at sites in the Bear River basin generally are associated with differences in basin geology, seasonal snowmelt runoff, Bear Lake outflows and diversions for irrigation, agricultural, and urban inputs, and 


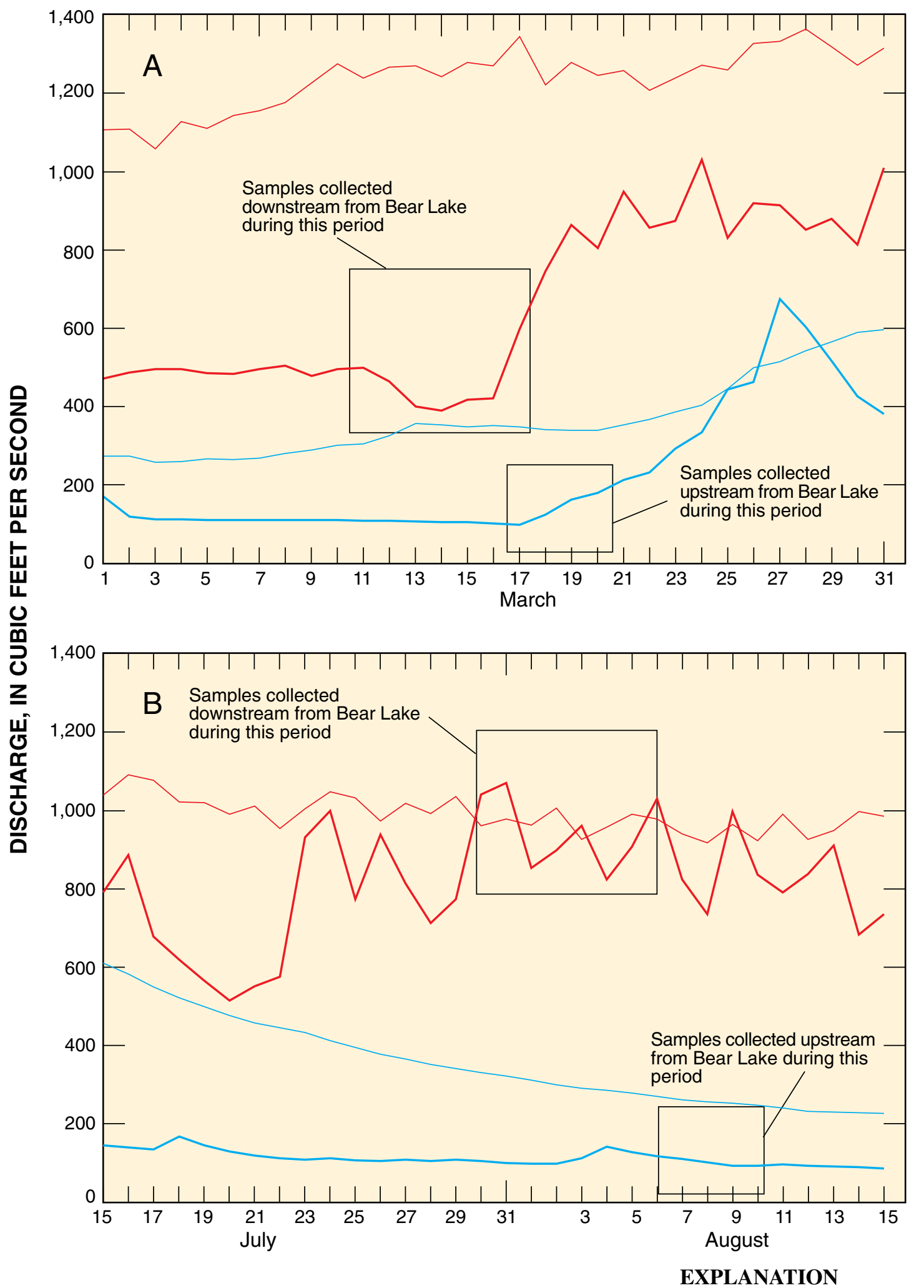

EXPLANATION

Mean daily discharge, site 48, 1971-2001

Daily mean discharge, site 48

Mean daily discharge, site 18, 1954-2001

Daily mean discharge, site 18

Figure 6. Discharge at Bear River sites 18 and 48, (A) March and (B) July-August 2001. 
ground-water discharge. For example, inflow of mineralized water from springs along the Malad River contributes to the high dissolved-solids concentration in the Bear River near Corinne (site 65) (Waddell and Price, 1972). Considerable amounts of dissolved salts also are contributed to the Bear River by mineralized spring water in the Soda Springs and Preston, Idaho areas. The return of water after use for irrigation further contributes to the increase of dissolved solids in the Bear River. Results of chemical analyses for water samples collected during both study periods are listed in table 9 .

The predominant ions in water samples collected in March from sites upstream from Preston were calcium and bicarbonate (fig. 7). Water samples collected from sites adjacent to and downstream from Preston, however, were enriched in sodium and chloride. Water samples collected from sites upstream from Bear Lake during July-August generally were of the calcium bicarbonate type, whereas magnesium and bicarbonate were the predominant ions in water samples collected from sites between Bear Lake and Cutler Reservoir. Calcium carbonate precipitates from water in Bear Lake, and as a result, the magnesium to calcium ratio in water pumped into the Bear River is higher than in the Bear River upstream from Bear Lake. The predominant ions in water samples collected in July-August from sites below Cutler Reservoir were sodium and chloride (fig. 7).

\section{March}

At sampling sites on the main stem of the Bear River during March, the concentration of dissolved solids ranged from $116 \mathrm{mg} / \mathrm{L}$ near the Utah-Wyoming Stateline (site 1) to $672 \mathrm{mg} / \mathrm{L}$ near Corinne (site 65) (fig. 8). Saleratus Creek (site 7, $760 \mathrm{mg} / \mathrm{L}$ ) and Twin Creek (site 13, $600 \mathrm{mg} / \mathrm{L}$ ) had the highest concentrations of dissolved solids in tributary streams upstream from Bear Lake. Relative to other main-stem sites sampled during March, sites upstream from Soda Springs generally had dissolved-solids concentrations less than the median concentration of $335 \mathrm{mg} / \mathrm{L}$ for samples collected during March (fig. 8).

Main-stem sites downstream from Soda Springs generally had dissolved-solids concentrations that were higher than the median concentration for samples collected during March (fig. 8). Soda Creek (site 32, $932 \mathrm{mg} / \mathrm{L}$ ) and Battle Creek (site 43, $1,080 \mathrm{mg} / \mathrm{L}$ ) had the highest concentrations of dissolved solids in tributaries downstream from Bear Lake, contributing to an increase in dissolved solids in the Bear River downstream from these confluences. Further, the dissolved-solids load in the Bear River below Soda Point Reservoir (site 34) was about eight times higher than above the reservoir (site 33) (fig. 9), principally because of the high concentration of dissolved solids in tributary inflow to the reservoir and increased discharge from reservoir releases. Tributaries above Cutler Reservoir discharged 1,340 tons/d to the Bear River, about 78 percent of the load calculated for the Bear River below Cutler Reservoir, near Collinston, Utah (site 62). Most of the tributary dissolvedsolids load was discharged from the Little Bear River (site
60, 950 tons/d) (fig. 9). The concentration of dissolved solids $(672 \mathrm{mg} / \mathrm{L})$ and the dissolved-solids load (3,060 tons/d) were substantially elevated in the Bear River near Corinne (site 65) relative to upstream main-stem sites.

\section{July-August}

During July-August, water-management practices such as irrigation diversions heavily influenced dissolved-solids concentrations at sampling sites on the Bear River. The concentration of dissolved solids ranged from $117 \mathrm{mg} / \mathrm{L}$ near the UtahWyoming Stateline (site 1) to $2,540 \mathrm{mg} / \mathrm{L}$ near Corinne (site 65) (fig. 10). The concentration of dissolved solids in tributary streams ranged from $196 \mathrm{mg} / \mathrm{L}$ in Stauffer Creek (site 28) to $1,540 \mathrm{mg} / \mathrm{L}$ in Soda Creek (site 32). Dissolved-solids concentrations in the Bear River generally were lower upstream from Bear Lake, except at sites 12 (above Bridger Creek) and 15 (below Pixley Dam), where concentrations were greater than $487 \mathrm{mg} / \mathrm{L}$ ( $75^{\text {th }}$ percentile of August samples) (fig. 10). Tributaries upstream from sites 12 and 15 had lower dissolved-solids concentrations than the main stem; hence, the increase in concentration at these sites is attributed to unmeasured sources such as irrigation return flow. Inflow from Smiths Fork (site 17) diluted the concentration of dissolved solids in the Bear River downstream from the confluence where concentrations were less than $334 \mathrm{mg} / \mathrm{L}$ (fig. 10). Dissolved-solids concentrations in the Bear River downstream from Bear Lake were highest at sites in and downstream from Cache Valley.

Inflow to the Bear River from Bear Lake via the Bear Lake Outlet Canal (fig. 3) was substantial (about $1,540 \mathrm{ft}^{3} / \mathrm{s}$ ) in July-August, and the dissolved-solids load (1,730 ton/d) to the Bear River was the highest of any inflow during this sampling period (fig. 11). However, because the concentration of dissolved solids in water released from the lake (site 23, 417 $\mathrm{mg} / \mathrm{L}$ ) was similar to that in the Bear River upstream from the lake (site $21,387 \mathrm{mg} / \mathrm{L}$ ), the concentration in the river downstream from Bear Lake was not substantially elevated. The pumpage of large amounts of water from Bear Lake diluted the combined contributions from tributaries and other sources of inflow so that concentrations of dissolved solids remained lower than $550 \mathrm{mg} / \mathrm{L}$ downstream to site 52 near Benson, Utah (fig. 10).

The dissolved-solids load entering Cutler Reservoir from the Bear River at site 52 near Benson was 1,470 tons/d (fig. 11). About 2,390 tons/d were removed from Cutler Reservoir, and of this amount, 2,320 tons discharged to the East and West Hammond Canals and 66 tons released from the dam discharged to the Bear River. No flow was detected entering Cutler Reservoir from the Little Bear River at Benson Marina (site 60), which includes the flow of the Logan River, Blacksmith Fork, Spring Creek (site 55), Hopkins Slough (site 57), and outflow from the Logan wastewater-treatment plant (site 58) (fig. 10). The concentration of dissolved solids in the Bear River below Cutler Reservoir, near Collinston (site 62, 980 $\mathrm{mg} / \mathrm{L}$ ), was considerably higher than above the reservoir (site $52,528 \mathrm{mg} / \mathrm{L}$ ), largely the result of an increase in sodium and 

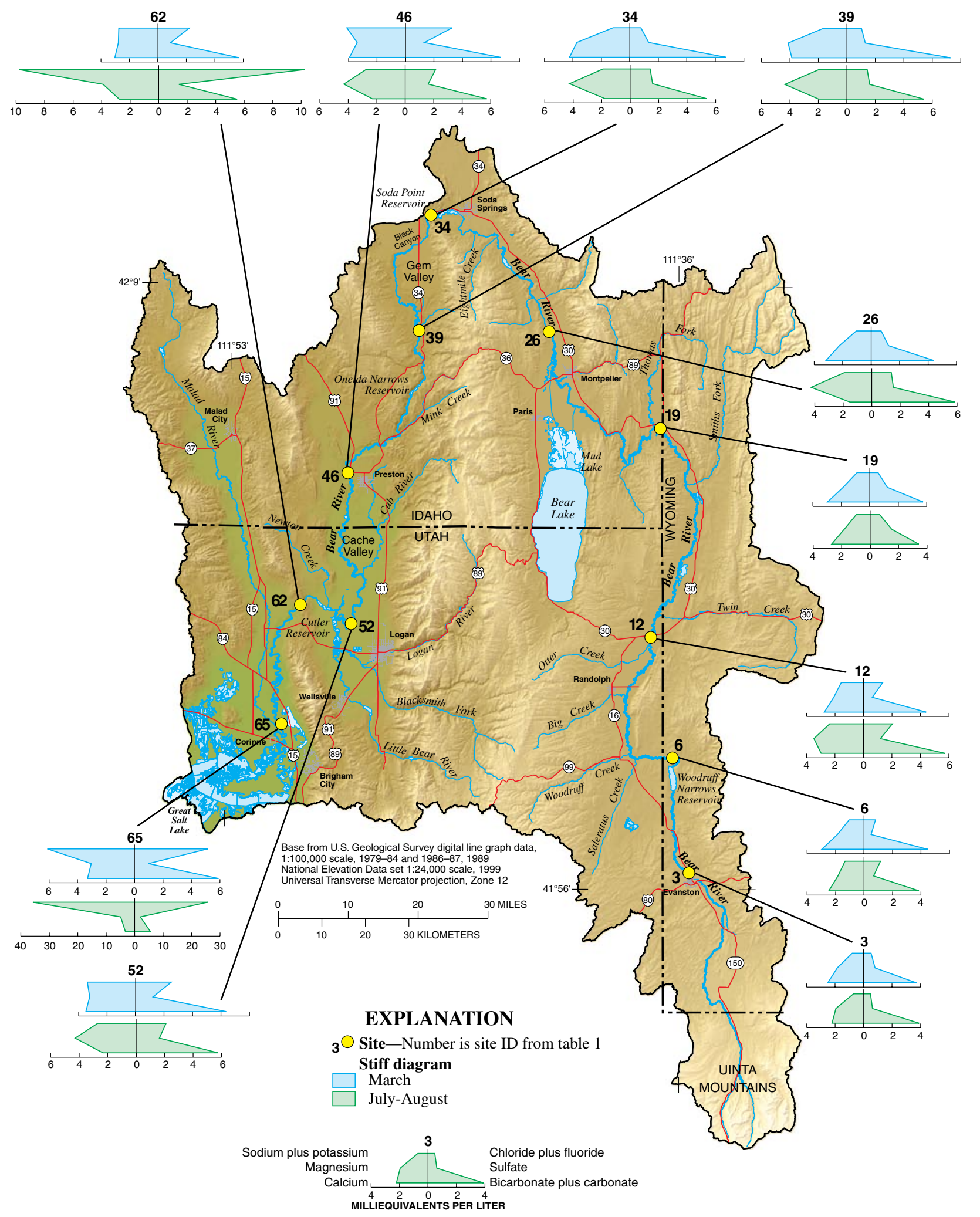

Figure 7. Chemical composition of water samples collected from selected main-stem sites in the Bear River basin, March and July-August 2001. 


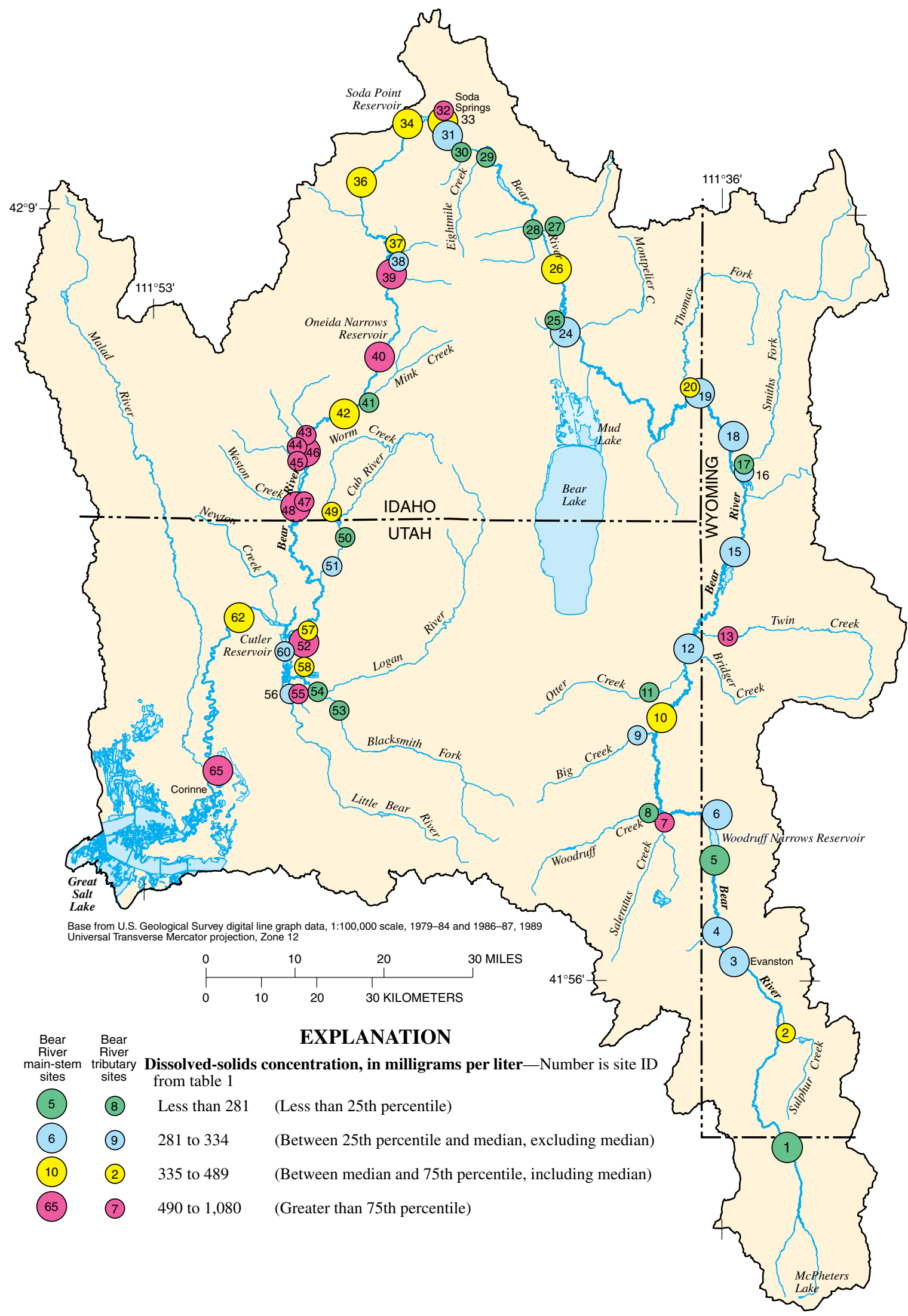

Figure 8. Concentration of dissolved solids in water samples collected from selected sites in the Bear River basin, March 2001. 


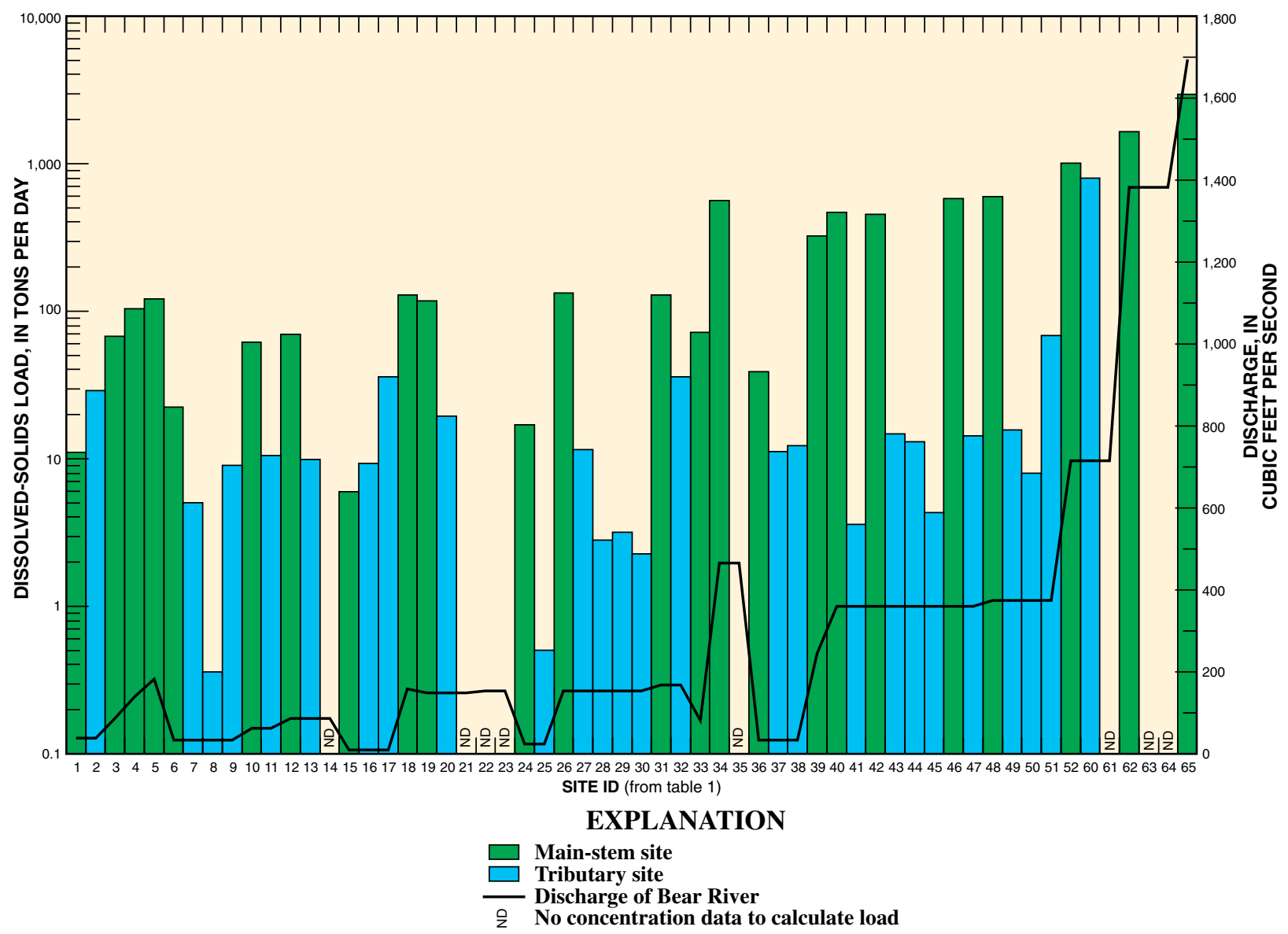

Figure 9. Dissolved-solids load calculated from water samples collected from selected sites in the Bear River basin, March 2001.

chloride (fig. 7). In addition, water samples collected from site 62 in March showed a dominance of calcium and bicarbonate. Because most of the water from the reservoir was diverted past site 62 and discharge in the river below the reservoir was low, the increase in dissolved solids probably was caused by ground-water inflow from mineralized springs downstream from the reservoir.

Utah waters protected for agricultural uses, such as irrigation of crops and stock watering, should have a dissolved-solids concentration of less than 1,200 mg/L to meet their beneficial-use designation (Utah Division of Administrative Rules, 2005). The Bear River from Cutler Reservoir to Corinne is designated for the beneficial use of agriculture; however, the concentration of dissolved solids in the Bear River near Corinne (site 65) in July-August was 2,540 mg/L and exceeded the Utah standard for agricultural uses. Some of the tributary streams in the reach between Cutler Reservoir and Corinne, such as the Malad River (site 64) and Salt Creek, which flows into the Bear River about $4 \mathrm{mi}$ upstream from Corrine and originates from Crystal Hot Springs, have naturally high concentrations of dissolved solids. Much of the water for the Malad River during low-flow periods is provided by mineralized hot springs. Waddell and Price (1972) reported concentrations as high as 5,700 $\mathrm{mg} / \mathrm{L}$ in the Malad River and Mundorff (1970) reported dissolved-solids concentrations as high as 45,500 mg/L in Salt Creek. These inputs have a substantial effect on the concentration of dissolved solids in the Bear River near Corinne, especially during periods of low flow.

\section{Suspended Sediment}

Suspended-sediment sources in the Bear River basin include unstable channels, watershed runoff, and stream-bank instability from hydrologic modification. The median concentrations of suspended sediment in Bear River basin streams during the two study periods were compared by using a twosided Wilcoxon rank-sum test (Ott and Longnecker, 2001, p. 287-299) and determined not to be statistically different (p-value 0.69). Concentrations of suspended sediment above the $75^{\text {th }}$ percentile, however, were much higher in samples collected from tributaries in March than in July-August (tables 6 and 7). Concentrations of suspended sediment for water samples collected during both study periods are listed in table 10 . 


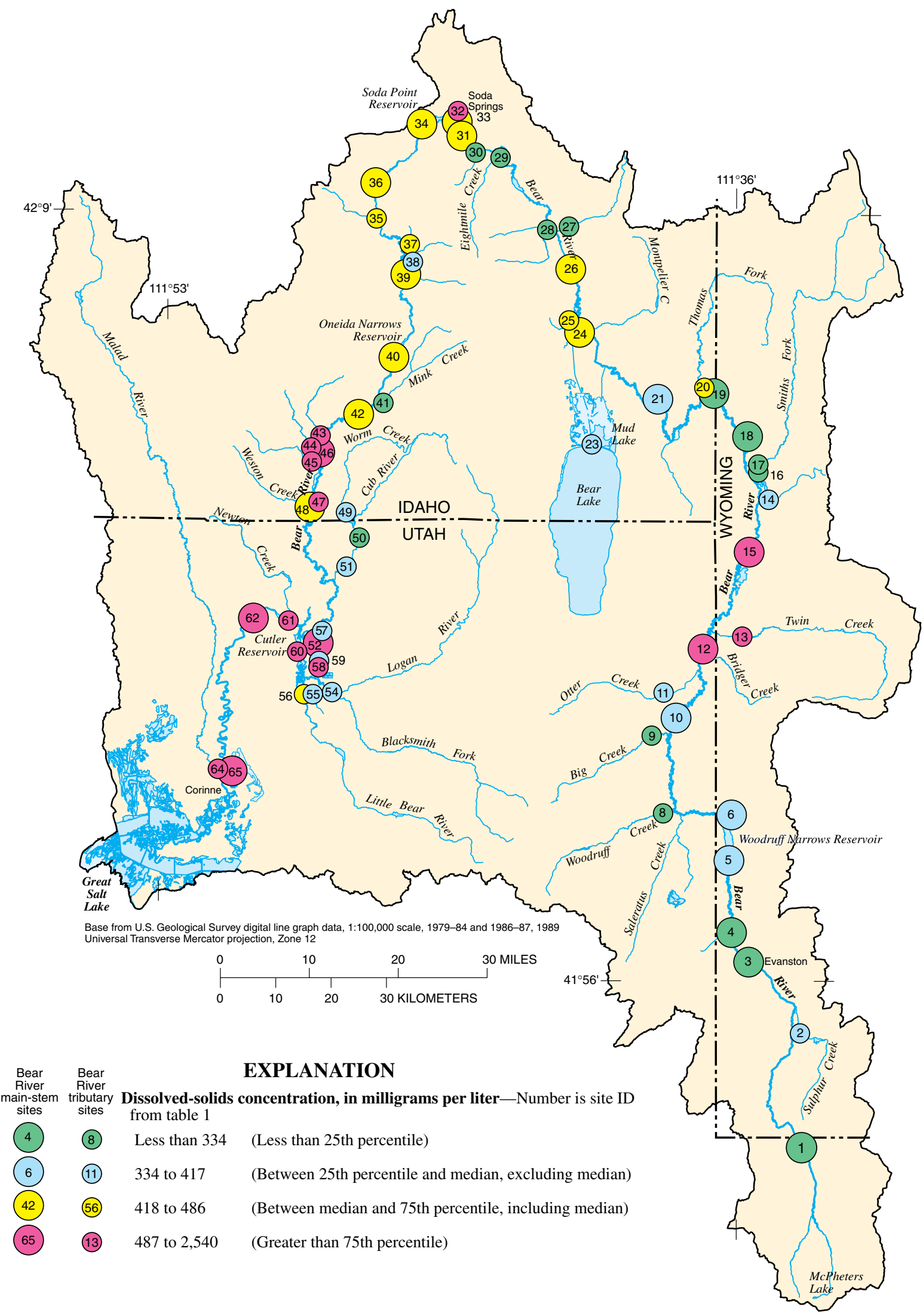

Figure 10. Concentration of dissolved solids in water samples collected from selected sites in the Bear River basin, July-August 2001. 


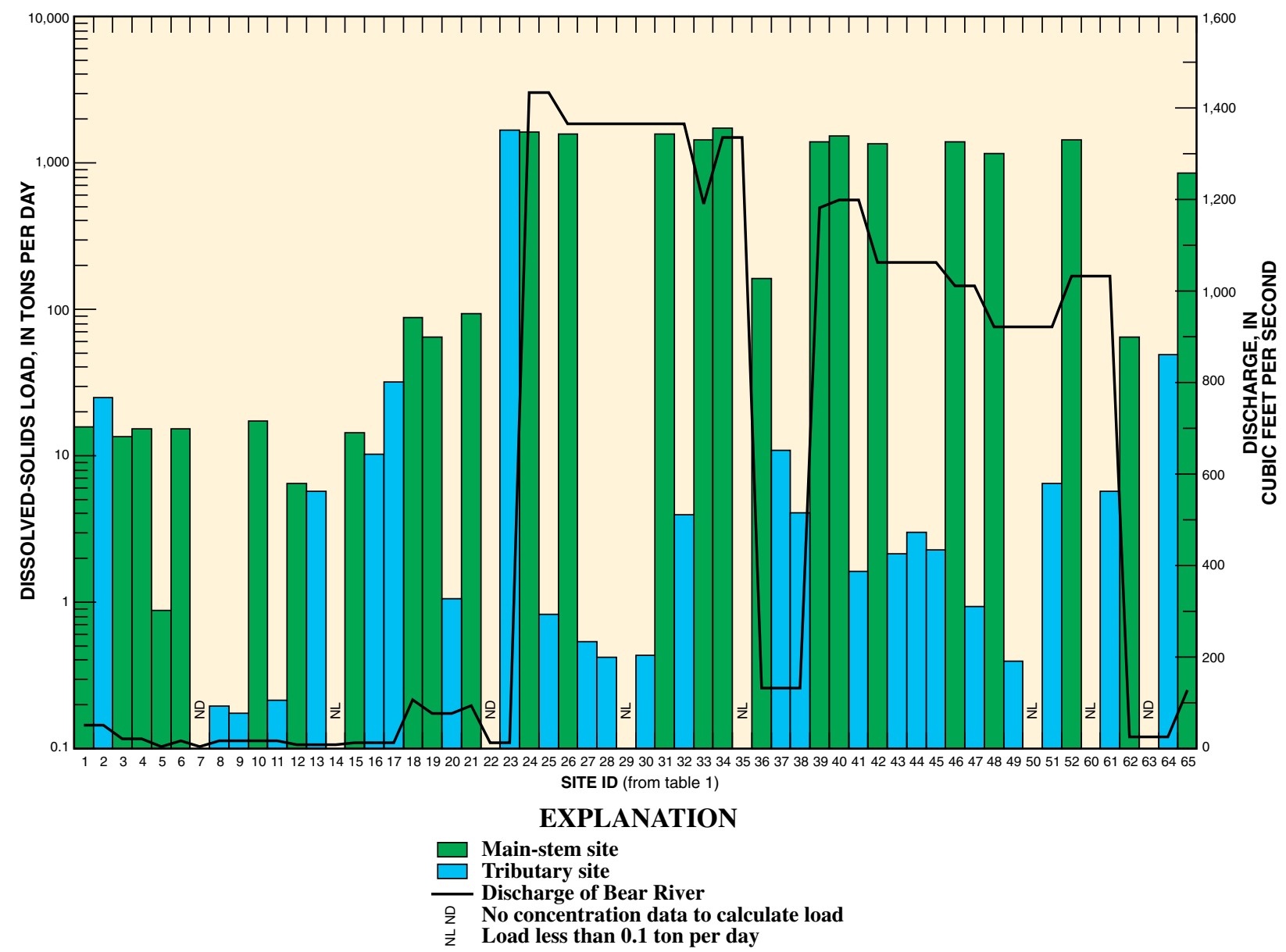

Figure 11. Dissolved-solids load calculated from water samples collected from selected sites in the Bear River basin, July-August 2001.

\section{March}

The median concentration of suspended sediment for main-stem sites sampled on the Bear River in March was 28 $\mathrm{mg} / \mathrm{L}$ (table 6) and ranged from $2 \mathrm{mg} / \mathrm{L}$ below Woodruff Narrows Reservoir (site 6) to $98 \mathrm{mg} / \mathrm{L}$ near Preston (site 46) (fig. 12). Tributary concentrations generally were higher than mainstem concentrations, with a median concentration of $48 \mathrm{mg} / \mathrm{L}$. Ten of the 14 samples collected in March with suspendedsediment concentrations greater than the overall $75^{\text {th }}$ percentile $(62 \mathrm{mg} / \mathrm{L})$ were from tributary streams (fig. 12$)$.

Suspended-sediment concentrations increased from the Utah-Wyoming Stateline (site 1, $3 \mathrm{mg} / \mathrm{L}$ ) downstream to Bear River above Woodruff Narrows Reservoir (site 5, $90 \mathrm{mg} / \mathrm{L}$ ). This substantial increase resulted from inputs from Sulphur Creek (site 2, $77 \mathrm{mg} / \mathrm{L}$ ) and other unmeasured inputs such as that from Yellow Creek (site 4, fig. 12). Deposition of sediment in Woodruff Narrows Reservoir, however, resulted in lower concentrations $(2 \mathrm{mg} / \mathrm{L})$ downstream at site 6 . Concentrations increased downstream to Border, Wyoming (site 19, $61 \mathrm{mg} / \mathrm{L}$ ) and then decreased downstream again at site 22 at the Stewart Dam diversion into Bear Lake (fig. 3). Suspended- sediment concentrations in the Bear River also decreased below Pixley Dam (site 15). The Bear River was entirely diverted into Mud Lake in March with no discharge to the Bear Lake Outlet Canal (fig. 3). Consequently, flow in the canal was composed mostly of ground water, resulting in low suspended-sediment concentrations downstream at sites 24 (4 $\mathrm{mg} / \mathrm{L}$ ) and 26 (9 mg/L) (fig. 12).

Suspended-sediment concentrations in the Bear River increased in the vicinity of Soda Springs downstream to Oneida Narrows Reservoir, but almost quadrupled from below the reservoir (site 40, $25 \mathrm{mg} / \mathrm{L}$ ) to near Preston (site $46,98 \mathrm{mg} / \mathrm{L}$ ), largely because of substantial contributions of sediment from Battle Creek (site 43), Deep Creek (site 44), and Fivemile Creek (site 45) (fig. 12). Suspended-sediment concentrations at sites $43(861 \mathrm{mg} / \mathrm{L})$ and $44(395 \mathrm{mg} / \mathrm{L})$ were the first and third highest in the Bear River basin during March. Further, these two tributaries contributed a combined suspended-sediment load of almost 26 tons/d to the Bear River (fig. 13), or about 38 percent of the increase in suspended-sediment load between Oneida Narrows Reservoir and Preston. Weston Creek (site 47) and the Cub River (site 51) also contributed substantial amounts of sediment to the Bear 


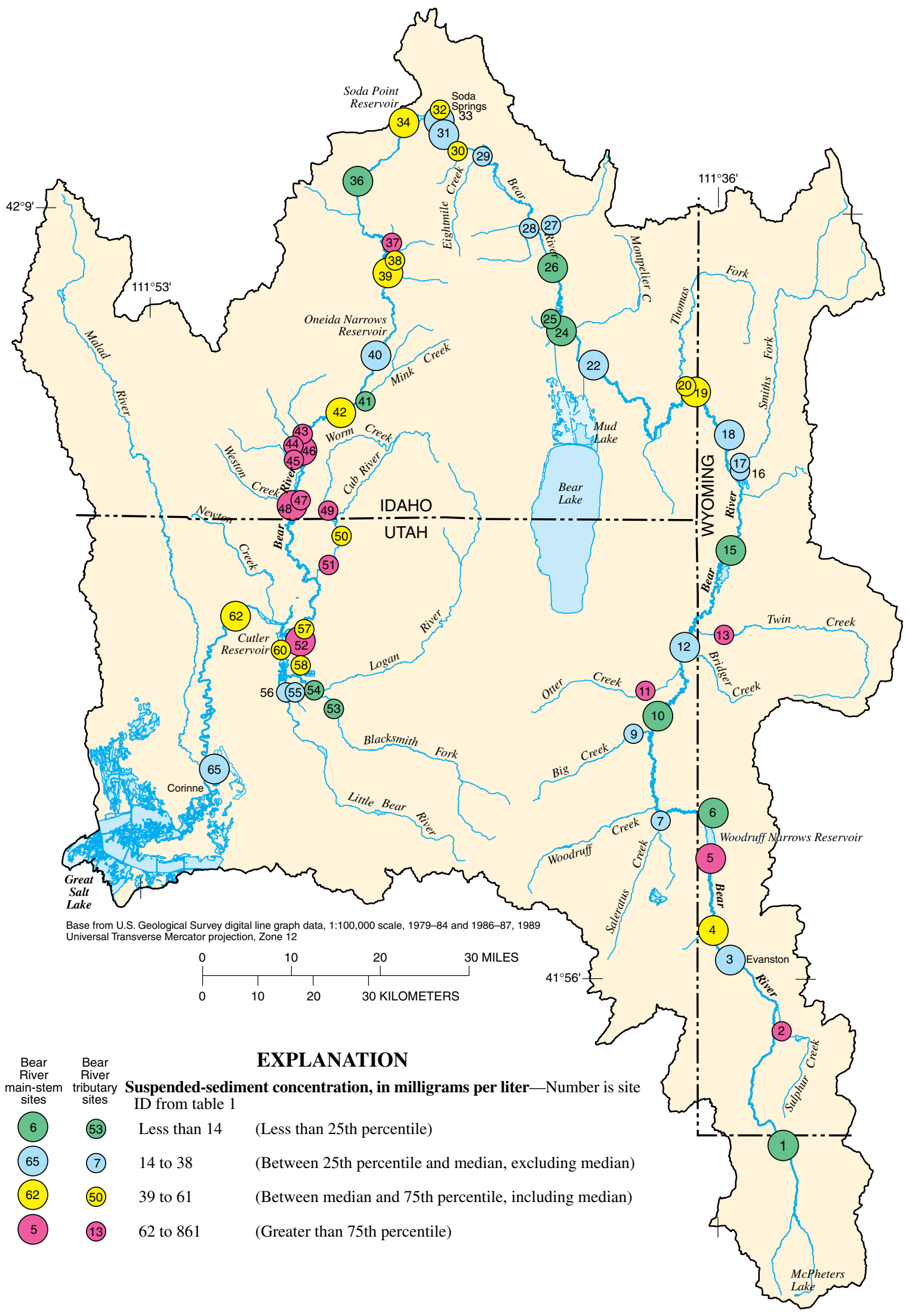

Figure 12. Concentration of suspended sediment in water samples collected from selected sites in the Bear River basin, March 2001. 


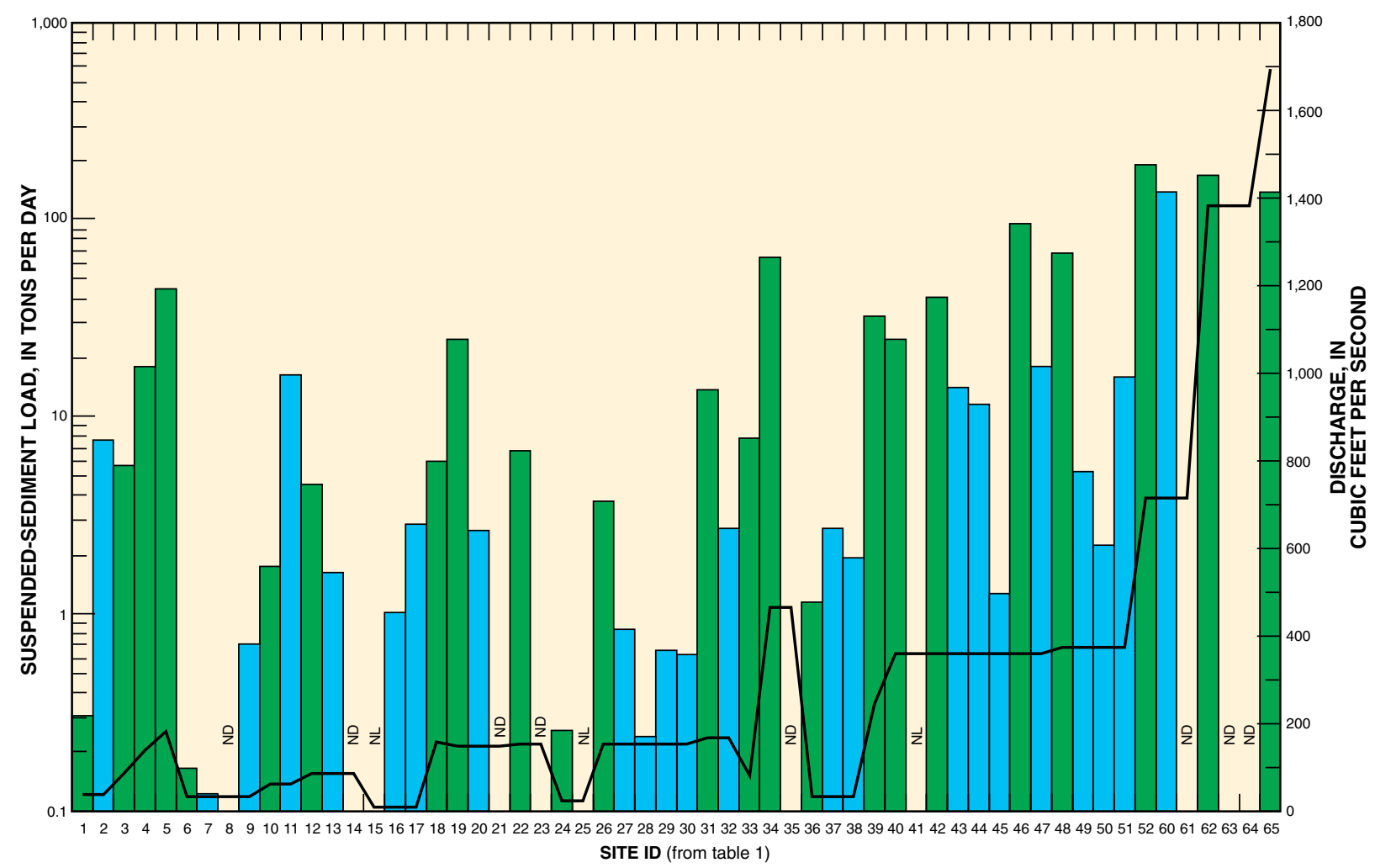

EXPLANATION

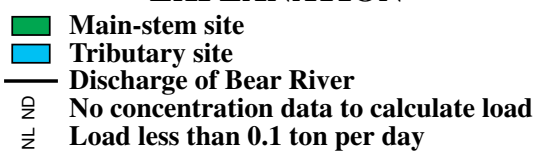

Figure 13. Suspended-sediment load calculated from water samples collected from selected sites in the Bear River basin, March 2001.

River during March, resulting in concentrations greater than the 75th percentile in the main stem downstream to Cutler Reservoir (fig. 12). Otter Creek (site 11) and Whiskey Creek (site 37) also had high sediment concentrations in March, which resulted in increased concentrations in the Bear River downstream from their respective confluences.

The Little Bear River and its tributaries were the largest contributors of sediment to the Bear River in March with respect to load (138 tons/d at site 60) (fig. 13). Sediment load into Cutler Reservoir from both the Bear and Little Bear Rivers was about 322 tons/d; however, only 163 tons/d discharged from Cutler Reservoir downstream at site 62, near Collinston. A substantial amount of sediment may have been deposited in the reservoir or in the low-gradient reach between the reservoir and site 62 .

\section{July-August}

The median suspended-sediment concentration for all sites sampled on the Bear River in July-August was $38 \mathrm{mg} / \mathrm{L}$ (table 7) and ranged from $2 \mathrm{mg} / \mathrm{L}$ at Evanston (site 3) to 141 $\mathrm{mg} / \mathrm{L}$ near Benson (site 52) (fig. 14). Tributary concentrations ranged from $3 \mathrm{mg} / \mathrm{L}$ in Densmore Creek (site 35) to 179 $\mathrm{mg} / \mathrm{L}$ in Soda Creek (site 32), with a median concentration of $36 \mathrm{mg} / \mathrm{L}$. Suspended-sediment concentration in Soda Creek increased threefold from the concentration measured at this site in March and was associated with a decrease in discharge from 17 to less than $1 \mathrm{ft}^{3} / \mathrm{s}$. The concentration below Pixley Dam (site 15) was $84 \mathrm{mg} / \mathrm{L}$, but inflow from Smiths Fork (site 17) had a suspended-sediment concentration of $9 \mathrm{mg} / \mathrm{L}$ and reduced concentrations in the Bear River at site 18, below the confluence, to $16 \mathrm{mg} / \mathrm{L}$ (fig. 14). The concentration of suspended sediment in the Bear River increased from Border, Wyoming (site 19, $16 \mathrm{mg} / \mathrm{L}$ ) downstream to the Stewart Dam diversion (site $22,52 \mathrm{mg} / \mathrm{L}$ ). The suspended-sediment concentration was only $17 \mathrm{mg} / \mathrm{L}$ in water discharged from Bear Lake into the Bear Lake Outlet Canal (site 23); however, the concentration increased as flow moved through the canal to site 24 $(51 \mathrm{mg} / \mathrm{L})$ and downstream to site $26(76 \mathrm{mg} / \mathrm{L})$. The increase in concentration along the canal probably is derived in large part from outflow from Mud Lake via Dingle Swamp (fig. 3). Because of the large discharge from Bear Lake, suspendedsediment loads were also the highest (176 tons/d at site 24) of any input to the Bear River in the basin (fig. 15). Concentrations of suspended sediment in the Bear River decreased below Soda Point, Oneida Narrows, and Cutler Reservoirs 


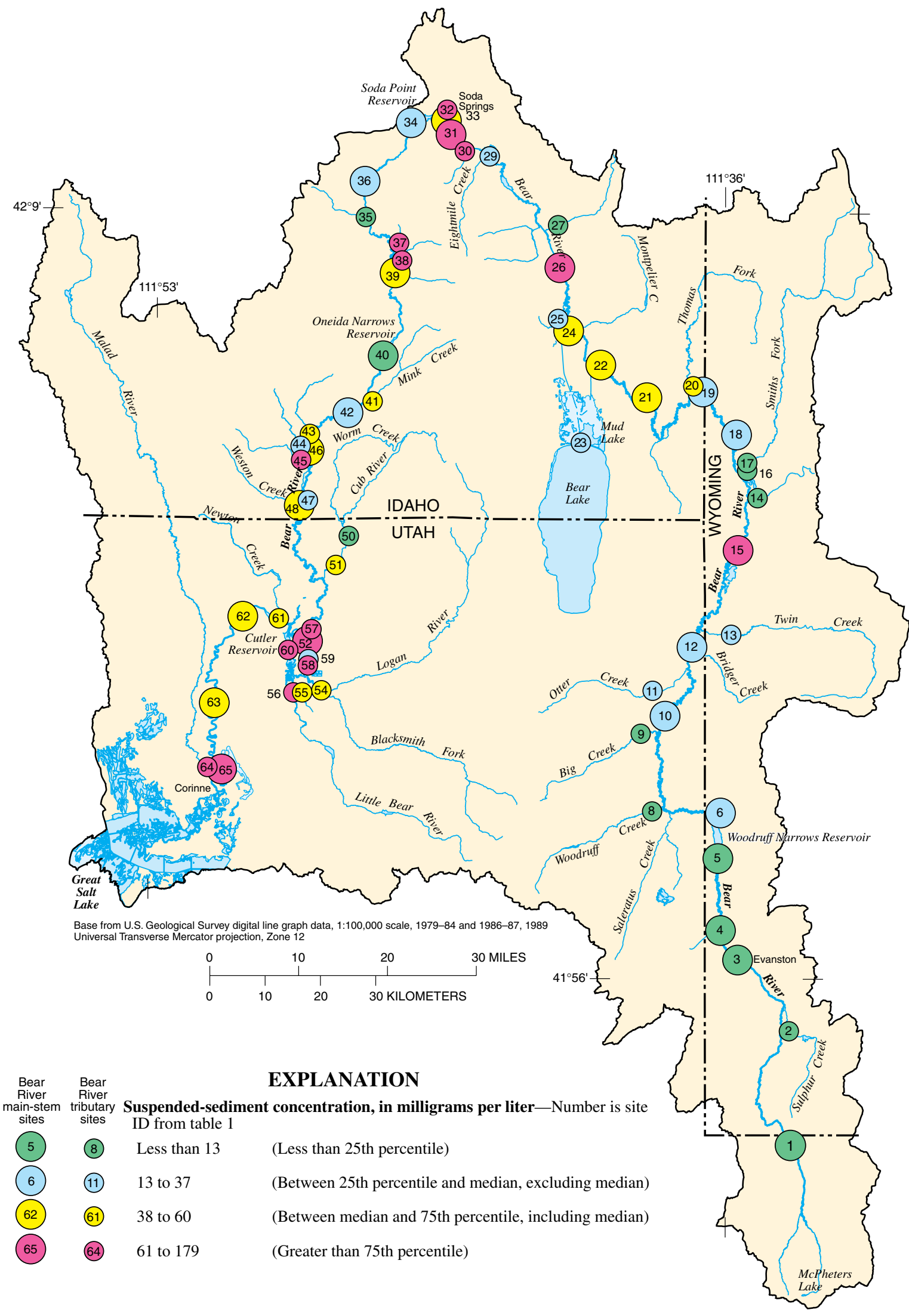

Figure 14. Concentration of suspended sediment in water samples collected from selected sites in the Bear River basin, July-August 2001. 


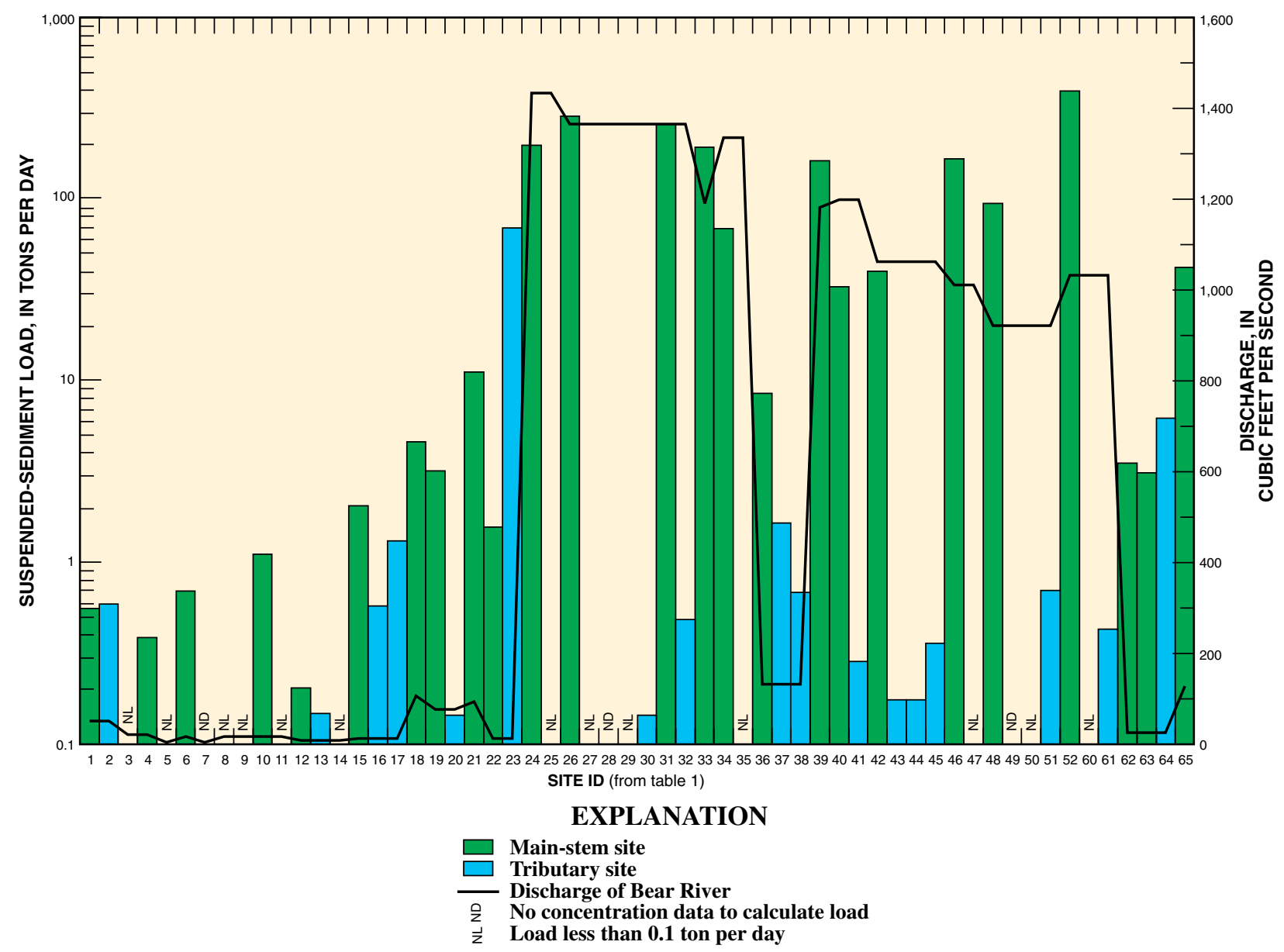

Figure 15. Suspended-sediment load calculated from water samples collected from selected sites in the Bear River basin, July-August 2001.

relative to sites above the reservoirs because of deposition of sediment in the reservoirs.

The suspended-sediment concentration in the Bear River near Benson (site 52,141 mg/L) was almost four times greater than the concentration upstream at the Idaho-Utah Stateline (site $48,38 \mathrm{mg} / \mathrm{L}$ ) (fig. 14). The suspended-sediment load also was highest at this site (392 tons/d) (fig. 15). Because the maximum concentration of suspended sediment in three tributaries entering this reach was only $41 \mathrm{mg} / \mathrm{L}$ (as measured at site 51 on the Cub River), elevated sediment concentrations near site 52 were likely caused by cutting of unstable stream banks resulting from flow modification. The concentration of suspended sediment was $111 \mathrm{mg} / \mathrm{L}$ in the Little Bear River at Benson Marina (site 60); however, there was no detectable flow in the river because of backwater from the Bear River. Consequently, there was no measurable contribution of sediment from the Little Bear River to the Bear River during the July-August sampling period.

Other tributaries to the Bear River that resulted in increases in suspended-sediment concentration downstream from their confluences with the river include Whiskey Creek (site 37), Trout Creek (site 38), and the Malad River (site 64). A suspended-sediment concentration of $148 \mathrm{mg} / \mathrm{L}$ in the
Malad River contributed to an increase of $75 \mathrm{mg} / \mathrm{L}$ in the Bear River between site 63 (near Deweyville) and site 65 (near Corinne), just upstream from its junction with Great Salt Lake (fig. 14). The suspended-sediment load in the Bear River also increased from 3 to 41 tons/d between sites 63 and 65 (fig. 15).

\section{Nutrients}

Nutrients, including nitrogen and phosphorus, are essential to the health and function of natural ecosystems (U.S. Geological Survey, 1999). Insufficient amounts of nutrients can lower growth rates of primary producers, such as aquatic vegetation, and limit the diversity and productivity of the ecosystem. Excessive amounts of nutrients can result in public health concerns and a general decline of the aquatic ecosystem health caused by accelerated growth of algae (eutrophication) and the large diurnal changes in dissolved oxygen and $\mathrm{pH}$ that sometimes occur. Nutrients occur naturally in streams because of mineral weathering and biological activity in the streambed sediment. Streams may receive additional nutrients from agricultural and urban runoff, atmospheric deposition, and waste- 
water discharge. Excessive amounts of nutrients have been identified as a source of impairment in many stream segments in the Bear River basin (table 3). Concentrations of nutrients in water samples collected during the March and July-August sampling periods are shown in table 10.

\section{Nitrogen}

Nitrogen species include ammonia, ammonia plus organic nitrogen, and nitrite plus nitrate. Excess concentrations of these constituents commonly are derived from agricultural sources such as fertilizers and feedlots. High nitrogen concentrations in surface water can degrade water quality, resulting in eutrophication and growth of algae, which, in turn, can create hypoxic (low oxygen) conditions that are detrimental to aquatic life (U.S. Geological Survey, 1999). High nitrate concentrations in drinking-water sources also can result in low oxygen levels in infants, causing methemoglobinemia or blue-baby syndrome (Eldridge, 2002). High levels of nitrite and organic nitrogen often are indicators of pollution caused by sewage or other organic waste. In oxygenated (non-polluted) waters, concentrations of nitrite are typically two orders of magnitude lower than nitrate concentrations.

\section{March}

Dissolved ammonia concentrations in the Bear River in March ranged from less than $0.021 \mathrm{mg} / \mathrm{L}$ (as N) at several sites to $0.473 \mathrm{mg} / \mathrm{L}$ near Corinne (site 65) (table 10), with a median concentration of $0.153 \mathrm{mg} / \mathrm{L}$ (table 6 ). Tributary concentrations also ranged from less than $0.021 \mathrm{mg} / \mathrm{L}$ at several sites to $1.43 \mathrm{mg} / \mathrm{L}$ in Spring Creek (site 55) with a median concentration of $0.149 \mathrm{mg} / \mathrm{L}$. Ammonia toxicity relative to aquatic organisms is dependent on $\mathrm{pH}$ and water temperature. Ammonia concentrations in water samples collected from the Bear River basin in March generally were much lower than national water-quality guidelines; however, the concentration in Spring Creek exceeded the EPA chronic criterion of $1.09 \mathrm{mg} / \mathrm{L}$ (U.S. Environmental Protection Agency, 1999). Ammonia is known to be a problem contaminant in Spring Creek and the Utah Division of Water Quality has prepared a TMDL document addressing the problem (PSOMAS and Cirrus Ecological Solutions, written commun., 2002).

Dissolved ammonia plus organic nitrogen concentrations in Bear River basin streams in March ranged from less than $0.1 \mathrm{mg} / \mathrm{L}$ near the Utah-Wyoming Stateline (site 1) to 2.4 $\mathrm{mg} / \mathrm{L}$ in Spring Creek (site 55) (table 10). Spring Creek is the only site where concentrations of all ammonia species exceeded $1.0 \mathrm{mg} / \mathrm{L}$, which likely results from agricultural practices (fertilizers) and livestock grazing in this part of the basin. The highest concentrations of ammonia plus organic nitrogen were measured in tributaries in the lower part of the basin below Oneida Narrows Reservoir.

Dissolved nitrite plus nitrate concentrations in the Bear River in March ranged from $0.044 \mathrm{mg} / \mathrm{L}$ (estimated) at site 12 (above Bridger Creek) to $1.76 \mathrm{mg} / \mathrm{L}$ near Collinston (site 62) (fig. 16), with a median concentration of $0.429 \mathrm{mg} / \mathrm{L}$ (table 6). Tributary concentrations ranged from $0.042 \mathrm{mg} / \mathrm{L}$ (estimated) at Smiths Fork (site 17) to $5.28 \mathrm{mg} / \mathrm{L}$ in Spring Creek (site $55)$, with a median concentration of $0.666 \mathrm{mg} / \mathrm{L}$. Dissolved nitrite plus nitrate concentrations in Worm Creek (site 49) were the second highest $(4.57 \mathrm{mg} / \mathrm{L}$, estimated) in the Bear River basin. The nitrate concentration in the water sample from Spring Creek was the only value that exceeded the Utah pollution indicant value of $4.0 \mathrm{mg} / \mathrm{L}$ (Utah Division of Administrative Rules, 2005). Nitrogen sources in the Spring Creek basin include animal waste, septic systems, and industrial discharge (PSOMAS and Cirrus Ecological Solutions, written commun., 2002).

Concentrations of dissolved nitrite plus nitrate measured and estimated in water samples from 12 of 13 sites upstream from Soda Springs (site 33) were less than the median concentration of $0.526 \mathrm{mg} / \mathrm{L}$ for all sites (fig. 16). The only exception was the sample from Thomas Fork (site 20), which had a concentration of $1.17 \mathrm{mg} / \mathrm{L}$. Concentrations in water samples from sites downstream from Soda Springs were greater than the median concentration, except for samples from the Logan River (site 54) and Blacksmith Fork (site 53). Higher nitrite plus nitrate concentrations in water samples from sites downstream from Soda Springs probably are caused by larger amounts of agricultural and urban inputs to the river in the segment between Soda Springs and Great Salt Lake. Also, as a result of warmer air temperatures, more snowmelt runoff occurred downstream from Soda Springs (the March average daily air temperature at Logan, Utah, was more than 11 degrees warmer than the average daily air temperature at Randolph, Utah), which resulted in transport of larger amounts of nitrite plus nitrate from these areas. An increase in discharge of the Bear River from $370 \mathrm{ft}^{3} / \mathrm{s}$ at the Idaho-Utah Stateline (site 48 ) to $1,380 \mathrm{ft}^{3} / \mathrm{s}$ at site 62 , near Collinston, also resulted in an increase in the nitrite plus nitrate load in the Bear River from 1.06 to 6.53 tons/d, respectively (fig. 17).

\section{July-August}

Dissolved ammonia concentrations in the Bear River in July-August ranged from less than $0.021 \mathrm{mg} / \mathrm{L}$ at several sites to $0.198 \mathrm{mg} / \mathrm{L}$ below Woodruff Narrows Reservoir (site 6) (table 10). Tributary concentrations ranged from less than $0.021 \mathrm{mg} / \mathrm{L}$ at many sites to $0.061 \mathrm{mg} / \mathrm{L}$ in Spring Creek (site 55). Ammonia concentrations in water samples from the Bear River basin in July-August were much lower than national water-quality guidelines, with a median concentration of 0.024 $\mathrm{mg} / \mathrm{L}$ (estimated) (table 7).

Dissolved ammonia plus organic nitrogen concentrations in Bear River basin streams in July-August were lower than those measured in March, ranging from less than $0.1 \mathrm{mg} / \mathrm{L}$ in Trout Creek at Thatcher (site 38) to $0.89 \mathrm{mg} / \mathrm{L}$ in the Bear River below Woodruff Narrows Reservoir (site 6) (table 10). Median concentrations of ammonia plus organic nitrogen were substantially greater (as much as one order of magnitude) than dissolved ammonia for samples collected during March and 


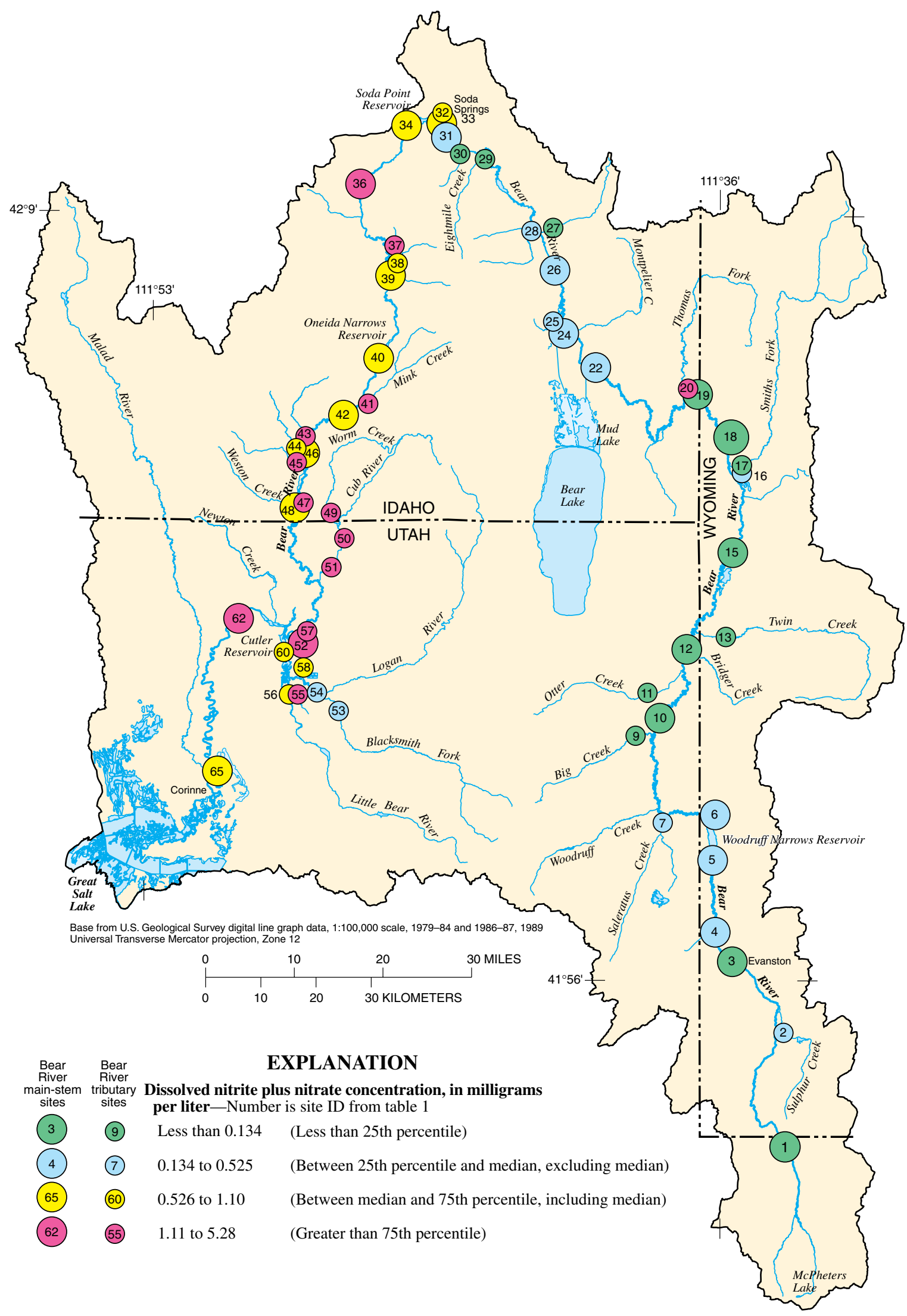

Figure 16. Concentration of dissolved nitrite plus nitrate in water samples collected from selected sites in the Bear River basin, March 2001. 


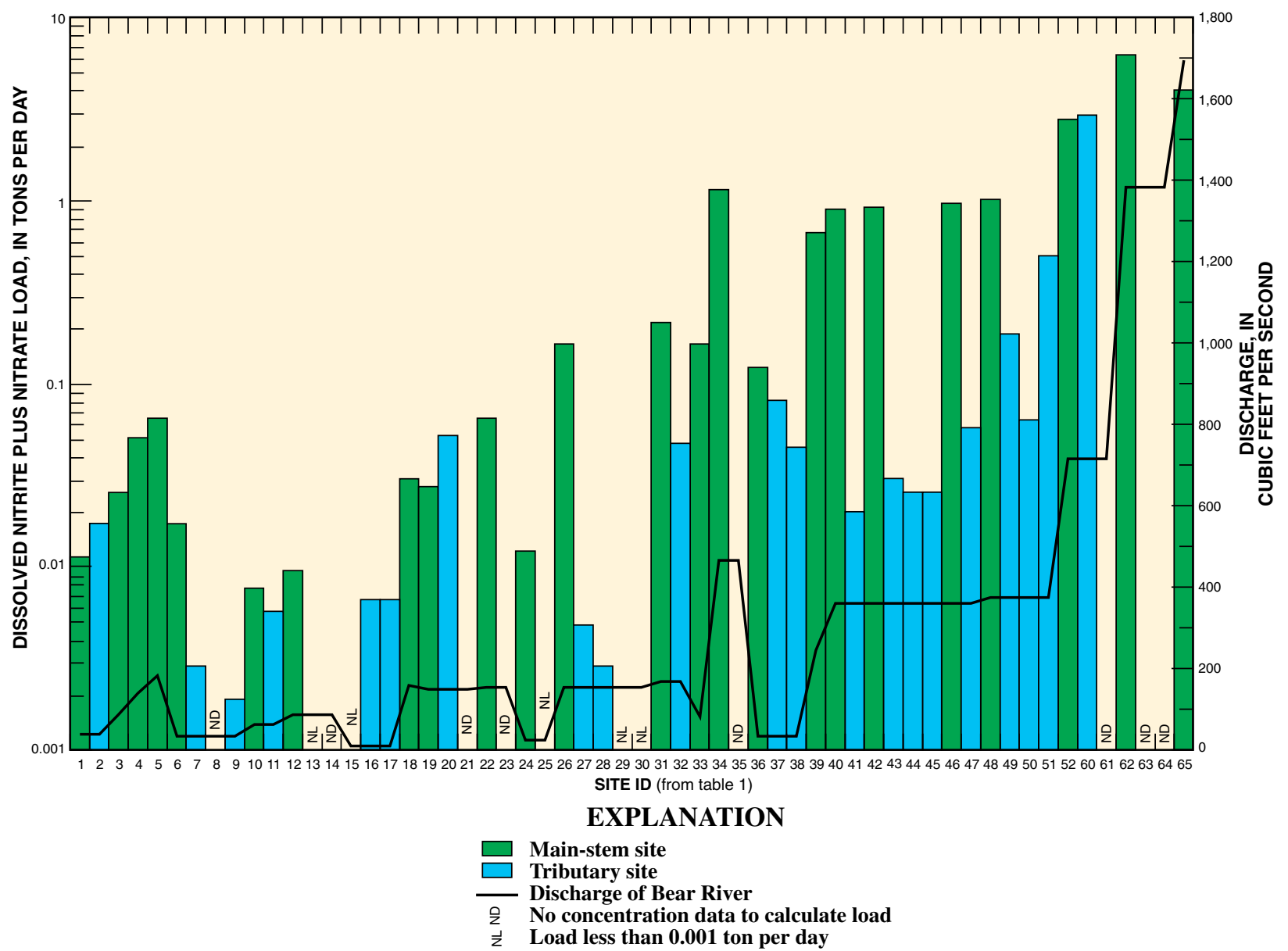

Figure 17. Dissolved nitrite plus nitrate load calculated from water samples collected from selected sites in the Bear River basin, March 2001.

July-August, indicating that most of the nitrogen is present as organic nitrogen. Concentrations of dissolved ammonia and ammonia plus organic nitrogen in the Bear River and particularly in tributaries typically were higher in March than in August, probably as a result of increased runoff from agricultural areas.

Dissolved nitrite plus nitrate concentrations in the Bear River in July-August ranged from $0.023 \mathrm{mg} / \mathrm{L}$ (estimated) at Border, Wyoming (site 19) to $0.69 \mathrm{mg} / \mathrm{L}$ near Corinne (site 65) (fig. 18), with a median concentration of $0.05 \mathrm{mg} / \mathrm{L}$ (table 7). Tributary concentrations ranged from less than $0.023 \mathrm{mg} / \mathrm{L}$ at many sites to $3.06 \mathrm{mg} / \mathrm{L}$ in Whiskey Creek (site 37), with a median concentration of $0.032 \mathrm{mg} / \mathrm{L}$. The median nitrite plus nitrate concentration in water samples collected from all sites in July-August $(0.041 \mathrm{mg} / \mathrm{L})$ was less than one-tenth of the median for all March water samples $(0.525 \mathrm{mg} / \mathrm{L})$, a result, in part, of increased uptake of nitrogen by aquatic plants and less surface runoff containing animal waste during the late summer.

As with the March distribution, water samples collected from most sites upstream from Soda Springs generally contained nitrite plus nitrate concentrations lower than the median (fig. 18). Water samples collected from sites downstream from Soda Springs generally contained concentrations of nitrite plus nitrate higher than the median (fig. 18). Most of the water samples containing nitrite plus nitrate concentrations higher than $0.22 \mathrm{mg} / \mathrm{L}\left(75^{\text {th }}\right.$ percentile) were collected from tributary streams.

Ground-water inflow to Black Canyon (fig. 1, site 36) contains a large amount of nutrients. Most of the flow of the Bear River upstream from site 36 is diverted past Black Canyon through a large diversion pipe. Daily discharge at the upstream end of Black Canyon and downstream from the diversion at Grace Dam (fig. 1) was about $100 \mathrm{ft}^{3} / \mathrm{s}$ (Herbert and others, 2002) and $130 \mathrm{ft}^{3} / \mathrm{s}$ (table 5) at site 36 just upstream from Grace power plant at the lower end of the canyon. The increase in discharge of $30 \mathrm{ft}^{3} / \mathrm{s}$ resulted from local ground-water inflow to the river in Black Canyon. The concentration of dissolved nitrite plus nitrate at the head of the canyon was assumed to be the same as at site 34 , below Soda Point Reservoir $(0.052 \mathrm{mg} / \mathrm{L})$, and the measured concentration at the lower end of the canyon at site 36 was $0.282 \mathrm{mg} / \mathrm{L}$. By using the flows and concentration at the head and lower end of Black Canyon, the average concentration of nitrite plus nitrate 


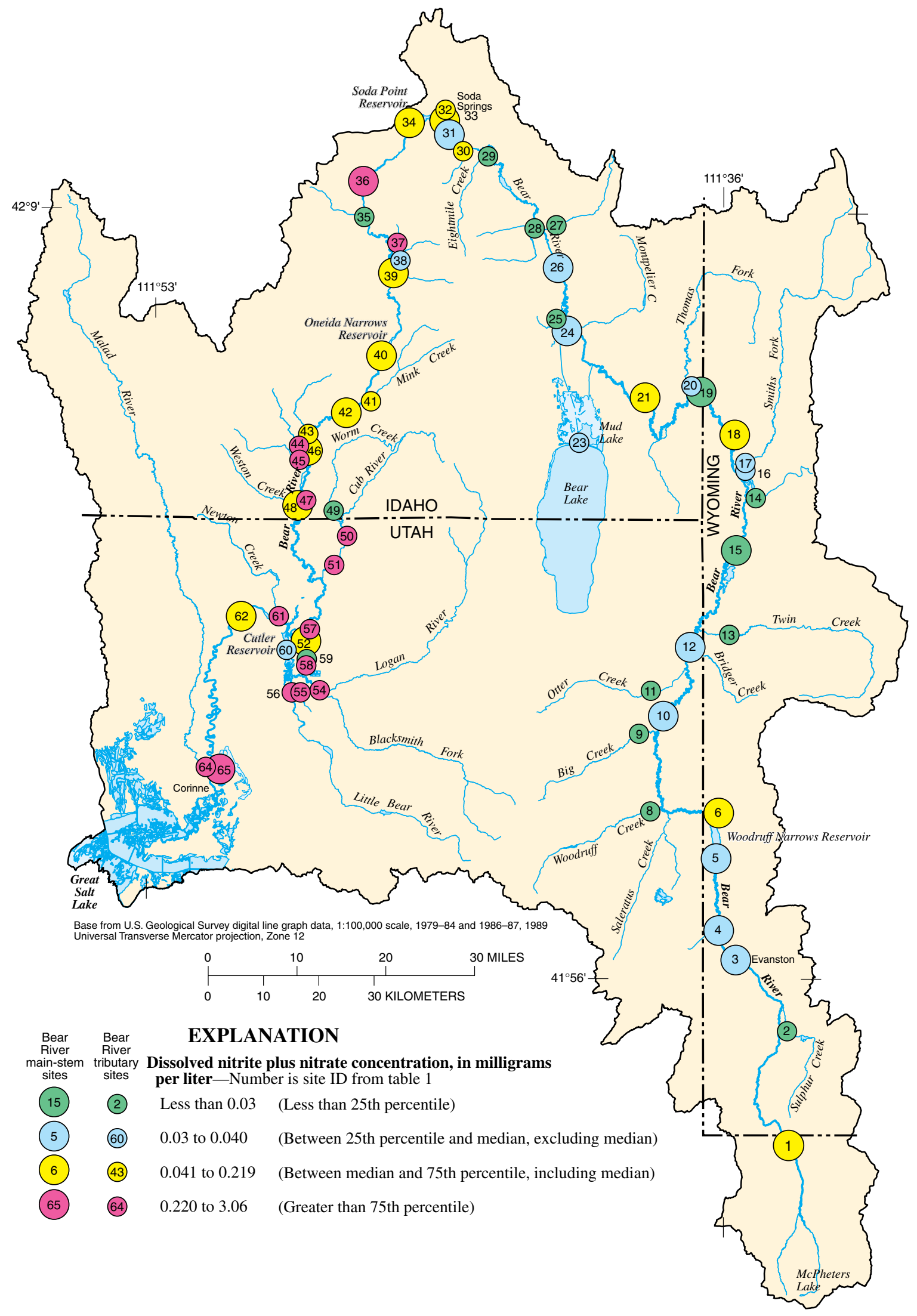

Figure 18. Concentration of dissolved nitrite plus nitrate in water samples collected from selected sites in the Bear River basin, July-August 2001. 
in ground-water inflow to the canyon was estimated to be 1 $\mathrm{mg} / \mathrm{L}$.

The dissolved nitrite plus nitrate concentration more than doubled (as did the loads) from site 34 at Alexander (0.052 $\mathrm{mg} / \mathrm{L})$ to site 39 near Thatcher $(0.111 \mathrm{mg} / \mathrm{L})$ (fig. 19), probably because of ground-water inflow downstream from Grace Dam (fig. 18). Water applied for irrigation in Gem Valley (fig. 1) readily infiltrates down to and through the highly permeable basalts in this area, bringing dissolved nitrite plus nitrate to the river. The largest nitrate loads to the Bear River were contributed by outflow from Bear Lake (site 23), Whiskey Creek (site 37), and from the Malad River (site 64) (fig. 19). A high nitrite plus nitrate concentration $(1.34 \mathrm{mg} / \mathrm{L})$ in inflow from the Malad River contributed to a two-order-of-magnitude increase in load between sites 62 (Collinston) and 65 (Corinne) on the Bear River.

\section{Phosphorus}

Phosphorus is a major cellular building component of plants and animals. It is used for adenosine triphosphate (ATP) formation, phospholipid production, and DNA synthesis.
Because plants readily take up the soluble form of phosphorus (orthophosphate), unless additional phosphorus is introduced to an aquatic system from anthropogenic sources, it is typically in short supply and can be a limiting nutrient. Unlike nitrogen, phosphorus does not form any toxic byproducts as it cycles through the ecosystem.

The reference conditions for total phosphorus for level III subecoregions 13, 18, and 19 in the Bear River basin are $0.029,0.022$, and $0.010 \mathrm{mg} / \mathrm{L}$ (based on the $25^{\text {th }}$ percentile), respectively (U.S. Environmental Protection Agency, 2000b). Forty-nine of the 57 sites sampled had a total phosphorus concentration exceeding these reference conditions in either March or July-August. The Bear River near the Utah-Wyoming Stateline (site 1) was the only site where total phosphorus concentrations in water samples collected in both March and July-August were less than the reference condition of $0.022 \mathrm{mg} / \mathrm{L}$ for Aggregate Nutrient Ecoregion III streams.

\section{March}

During March, concentrations of total phosphorus in the Bear River ranged from less than $0.004 \mathrm{mg} / \mathrm{L}$ near the UtahWyoming Stateline (site 1) to $0.49 \mathrm{mg} / \mathrm{L}$ near Collinston (site

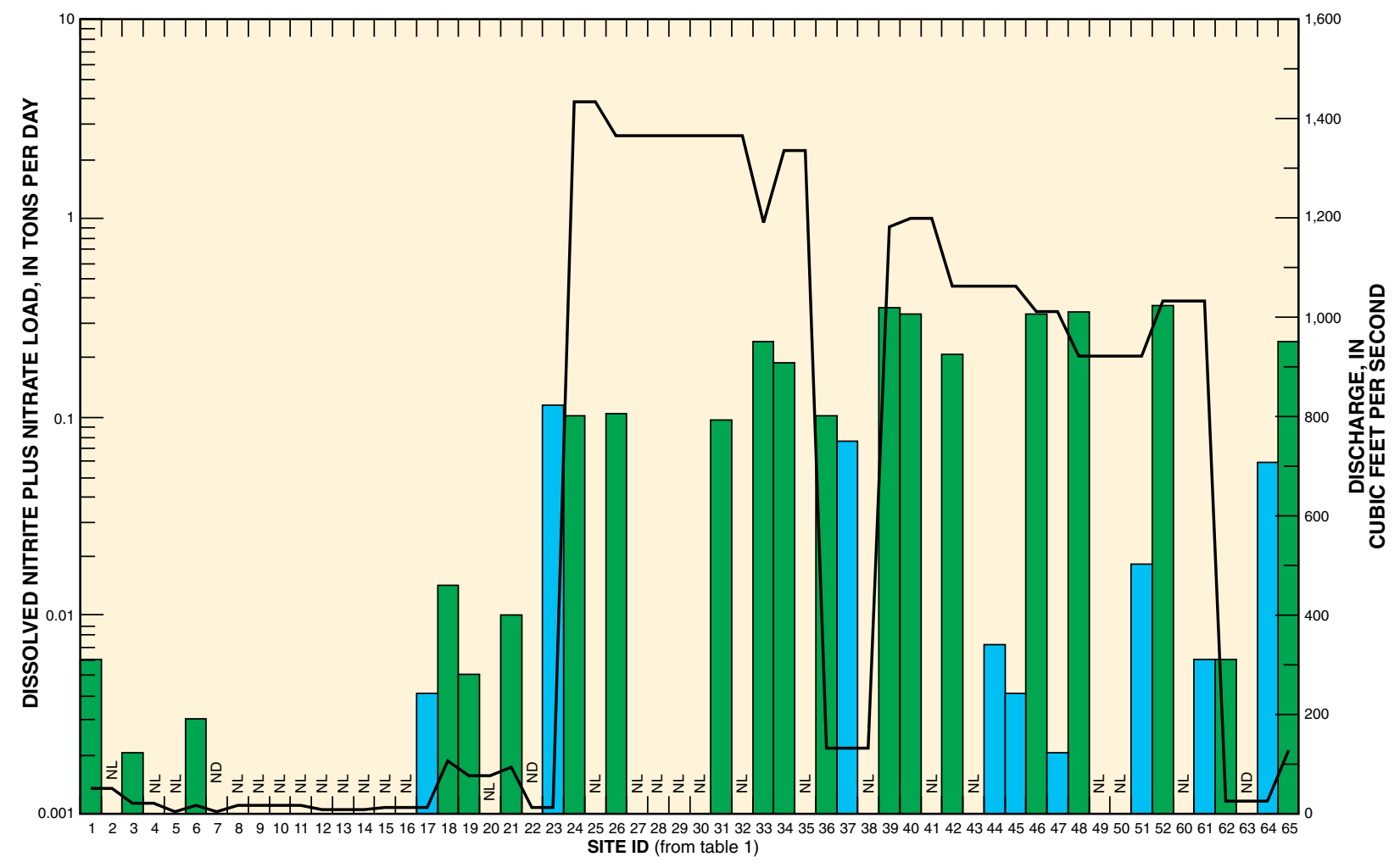

EXPLANATION

Main-stem site

Tributary site

Discharge of Bear River

\& No concentration data to calculate load

$\vec{z}$ Load less than 0.001 ton per day

Figure 19. Dissolved nitrite plus nitrate load calculated from water samples collected from selected sites in the Bear River basin, July-August 2001. 
62) (fig. 20). Total phosphorus concentrations in tributary streams ranged from less than $0.02 \mathrm{mg} / \mathrm{L}$ in Ovid Creek (site 25 ) and Blacksmith Fork (site 53) to $2.4 \mathrm{mg} / \mathrm{L}$ in the Logan wastewater-treatment plant ditch (site 58).

Concentrations of total phosphorus in the Bear River generally increased from upstream to downstream (fig. 20). Sites upstream from Preston (site 46) generally had lower total phosphorus concentrations (less than $0.073 \mathrm{mg} / \mathrm{L}$ ); sites downstream from Preston had higher concentrations ( 0.073 to $0.49 \mathrm{mg} / \mathrm{L}$ ). Tributaries contributed substantial amounts of total phosphorus to the Bear River. The total phosphorus concentration was less than $0.004 \mathrm{mg} / \mathrm{L}$ in the Bear River near the Utah-Wyoming Stateline (site 1); however, inputs from Sulphur Creek (site 2, $0.441 \mathrm{mg} / \mathrm{L}$ ) and possibly Yellow Creek (site $4,0.167 \mathrm{mg} / \mathrm{L}$ ) contributed to the increase to $0.273 \mathrm{mg} / \mathrm{L}$ in the Bear River above Woodruff Narrows Reservoir (site 5) (fig. 20). The total phosphorus concentration below the reservoir (site $6,0.05 \mathrm{mg} / \mathrm{L}$ ) was much lower, likely resulting from deposition of phosphorus in the reservoir, probably in association with suspended sediment. Inputs from site 7 (Saleratus Creek, $0.317 \mathrm{mg} / \mathrm{L}$ ) and site 8 (Genes (Woodruff) Creek, 0.347 $\mathrm{mg} / \mathrm{L}$ ) likely increased total phosphorus concentration in the main stem downstream from these confluences. Smiths Fork (site 17) contributed a substantial amount of flow to the Bear River but had a relatively dilute total phosphorus concentration $(0.028 \mathrm{mg} / \mathrm{L})$. The concentration of total phosphorus remained low in the Bear River downstream to Soda Point Reservoir (site $33,0.035 \mathrm{mg} / \mathrm{L}$ ).

Most sampled tributaries below Soda Point Reservoir contributed to increasing total phosphorus concentrations in the Bear River (fig. 20). Many sampled tributaries downstream from Preston and all Bear River sites downstream from the Idaho-Utah Stateline exceeded $0.273 \mathrm{mg} / \mathrm{L}$ (the $75^{\text {th }}$ percentile) total phosphorus. The highest total phosphorus concentration $(1.27 \mathrm{mg} / \mathrm{L})$ in March was in Spring Creek (site 55). The largest tributary load (1.3 tons/d) was from the Little Bear River at Benson Marina (site 60) (fig. 21), which also includes substantial loads from Spring Creek and the Logan wastewater-treatment plant (site 58). Outflow from the treatment plant contributed $2.4 \mathrm{mg} / \mathrm{L}$ total phosphorus to the Little Bear River. Inflow from the Little Bear River into Cutler Reservoir at site $60(0.45 \mathrm{mg} / \mathrm{L})$ increased the total phosphorus concentration in the Bear River from $0.29 \mathrm{mg} / \mathrm{L}$ at site 52 (near Benson) to 0.49 $\mathrm{mg} / \mathrm{L}$ at site 62 (near Collinston). Total phosphorus concentration in the Cub River (site 51, $0.394 \mathrm{mg} / \mathrm{L}$ ) also contributed to an increase in concentration and load in the Bear River between sites 48 and 52 (fig. 21). The concentration of total phosphorus in the Bear River near Corinne (site 65) decreased to $0.289 \mathrm{mg} / \mathrm{L}$, but was still greater than the $75^{\text {th }}$ percentile.

\section{July-August}

Total phosphorus concentrations in the Bear River in July-August ranged from $0.005 \mathrm{mg} / \mathrm{L}$ near the Utah-Wyoming Stateline (site 1) to $0.287 \mathrm{mg} / \mathrm{L}$ near Corinne (site 65) (fig. 22). Total phosphorus in water samples from tributary streams ranged from less than $0.02 \mathrm{mg} / \mathrm{L}$ in Twin Creek (site 13) to 2.3 $\mathrm{mg} / \mathrm{L}$ in the Logan wastewater-treatment plant ditch (site 58 ).

Concentrations of total phosphorus generally were less than $0.067 \mathrm{mg} / \mathrm{L}$ (median) in water samples collected from sites upstream from Bear Lake (fig. 22), except at site 6, Bear River below Woodruff Narrows Reservoir $(0.198 \mathrm{mg} / \mathrm{L})$ and site 15, Bear River below Pixley Dam $(0.107 \mathrm{mg} / \mathrm{L})$. Because of the low level of Woodruff Narrows Reservoir in JulyAugust, conditions may have been conducive for resuspension of phosphorus in reservoir sediments into the water column through wind action or downcutting.

Total phosphorus loads in the Bear River increased substantially downstream from Bear Lake (fig. 23). The concentration of total phosphorus in the water sample collected from the Bear Lake outflow (site 23) was very low $(0.014 \mathrm{mg} / \mathrm{L})$; however, the concentration near the end of the Bear Lake Outlet Canal (site 24, fig. 3) was nearly five times higher $(0.067 \mathrm{mg} / \mathrm{L})$, resulting in a load of about 0.26 tons/d to the Bear River (fig. 23). Most of the additional phosphorus was in the particulate form and may have been bound to sediment or contained in algae in Mud Lake (fig. 3), which then was transported into the outlet canal. Concentrations of total phosphorus generally were between $0.029 \mathrm{mg} / \mathrm{L}$ and 0.110 $\mathrm{mg} / \mathrm{L}$ in water samples collected from sites downstream from Bear Lake (fig. 22). Total phosphorus concentrations increased downstream from Preston (site 46), where concentrations at most sites exceeded $0.110 \mathrm{mg} / \mathrm{L}$. Inflow from the Cub River and its tributaries also contributed to an increase in total phosphorus in the Bear River between sites 48 and 52 (fig. 22). Tributary streams generally contributed considerably less phosphorus to the Bear River in July-August than in March.

\section{Pesticides}

Water samples collected from selected sites in the Bear River basin were analyzed for pesticides (herbicides, insecticides, and degradates). Pesticide samples were collected at 5 sites in March and 15 sites during July-August. Samples collected from all sites were analyzed for 47 pesticides, 8 of which were detected, and samples collected at 9 sites in July-August were analyzed for an additional 61 pesticides, 4 of which were detected (tables 11 and 12). Pesticides were detected at all the sites, either in March or July-August, and all detections were less than $0.1 \mu \mathrm{g} / \mathrm{L}$ (table 11). Eighty-five percent of the samples had at least one pesticide detected and 70 percent had more than one detected. Concentrations of pesticides in samples collected during both study periods are shown in table 12.

Malathion, an organophosphate used to control mosquitoes, lawn and garden pests, and livestock pests, was the insecticide detected most frequently (table 11). Prometon, a persistent broad-spectrum herbicide used for bare-ground weed control around buildings, along fences and roadways, and in other non-crop areas, was the herbicide detected most frequently. Atrazine, a herbicide that selectively controls 


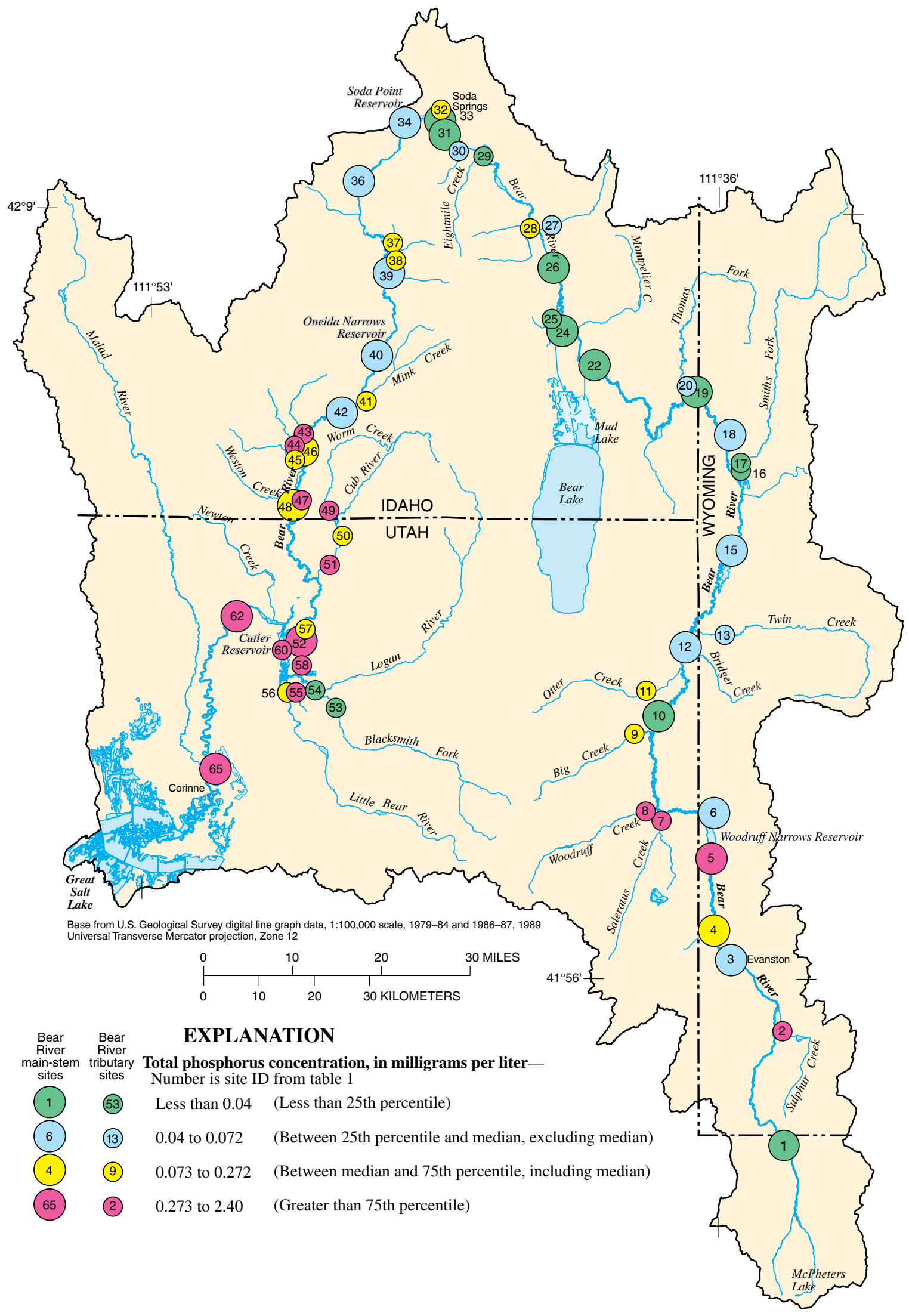

Figure 20. Concentration of total phosphorus in water samples collected from selected sites in the Bear River basin, March 2001. 


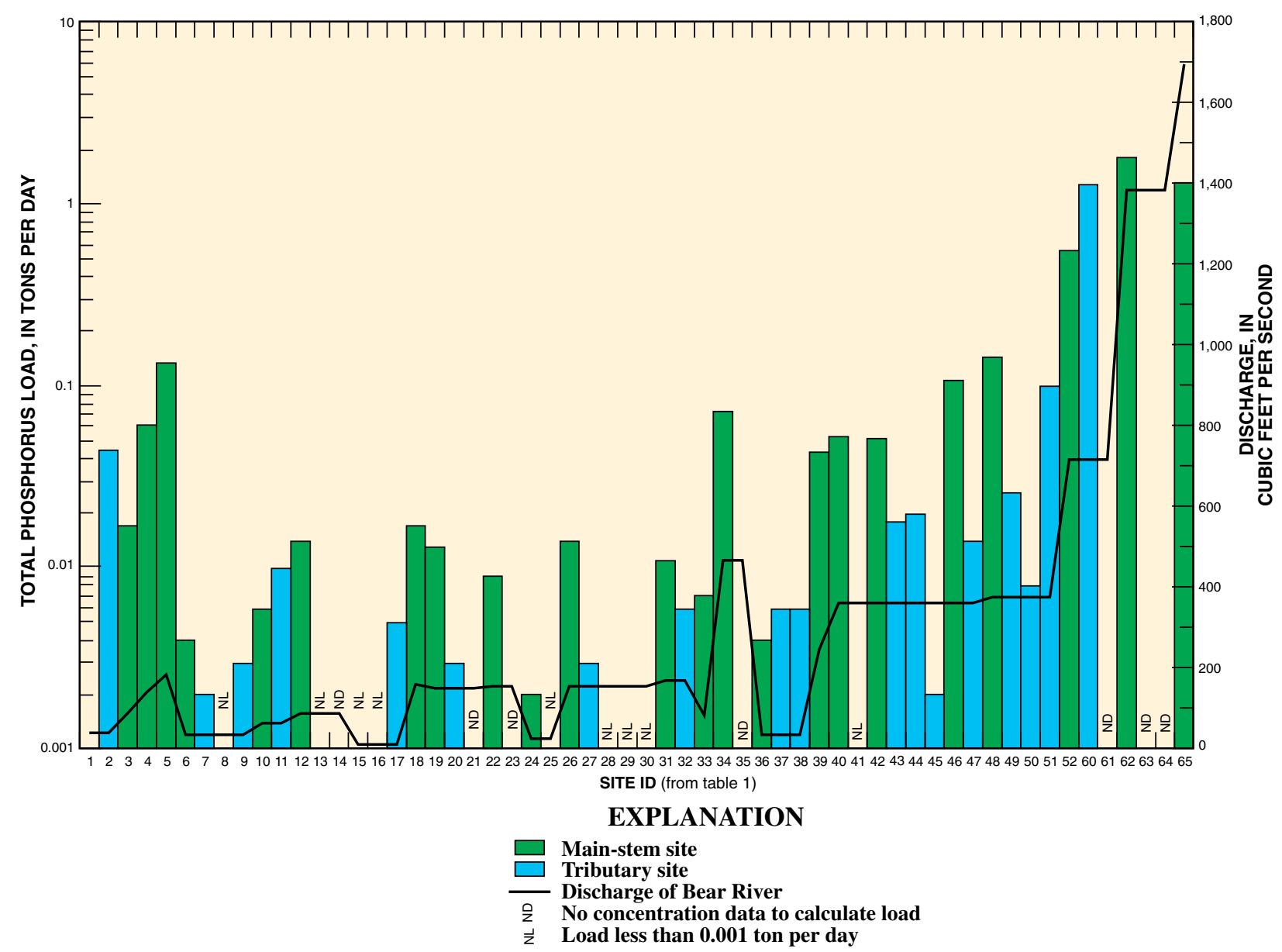

Figure 21. Total phosphorus load calculated from water samples collected from selected sites in the Bear River basin, March 2001.

broadleaf weeds without injury to the target crop, was the pesticide detected in the highest concentration $(0.096 \mu \mathrm{g} / \mathrm{L}$, estimated).

Aquatic-life guidelines have been established for 7 of the 12 pesticides detected (table 11). The Canadian Council of Ministers of the Environment (2001) and U.S. Environmental Protection Agency $(2002,2004)$ established these guidelines as maximum levels that should not be exceeded if aquatic life is to be protected. The concentrations measured in water samples from the Bear River basin were less than the stated guidelines, indicating that there was not a threat to aquatic life in the Bear River during both study periods. The consequences to aquatic life from the presence of mixtures of these pesticides, however, are not known. The EPA has established human-health standards for 9 of the 12 pesticides detected (table 11). None of the pesticide concentrations in water samples from Bear River basin sites exceeded these guidelines, and all but atrazine were at least two orders of magnitude less than human-health standards.

\section{Periphyton Chlorophyll a}

Periphyton (algae attached to an aquatic substrate) samples were collected at 14 sites on the Bear River during August by scraping rocks, snags, or coarse sediments. These samples were then analyzed for CHL A, which is the most common photosynthetic pigment in the sample and commonly is used to compare the abundance of algae among sites. CHL A concentrations ranged from $21 \mathrm{mg} / \mathrm{m}^{2}$ at site 1 (Bear River near Utah-Wyoming Stateline) to $416 \mathrm{mg} / \mathrm{m}^{2}$ at site 40 (Bear River below Oneida Narrows Reservoir) (table 13). Algal levels in the Bear River ranged from those that presumably would be present under natural conditions to those indicative of eutrophication. Factors that may affect river algal levels include scouring, shading, grazing, toxic chemicals, and available nutrients.

Concentrations of CHL A below the $25^{\text {th }}$ percentile (low concentrations) and above the $75^{\text {th }}$ percentile (high concentrations) in periphyton samples throughout the Bear River basin (fig. 24) indicate that algal communities are probably responding to a complex mix of local conditions, including light and nutrient availability, substrate, and discharge. No spatial 


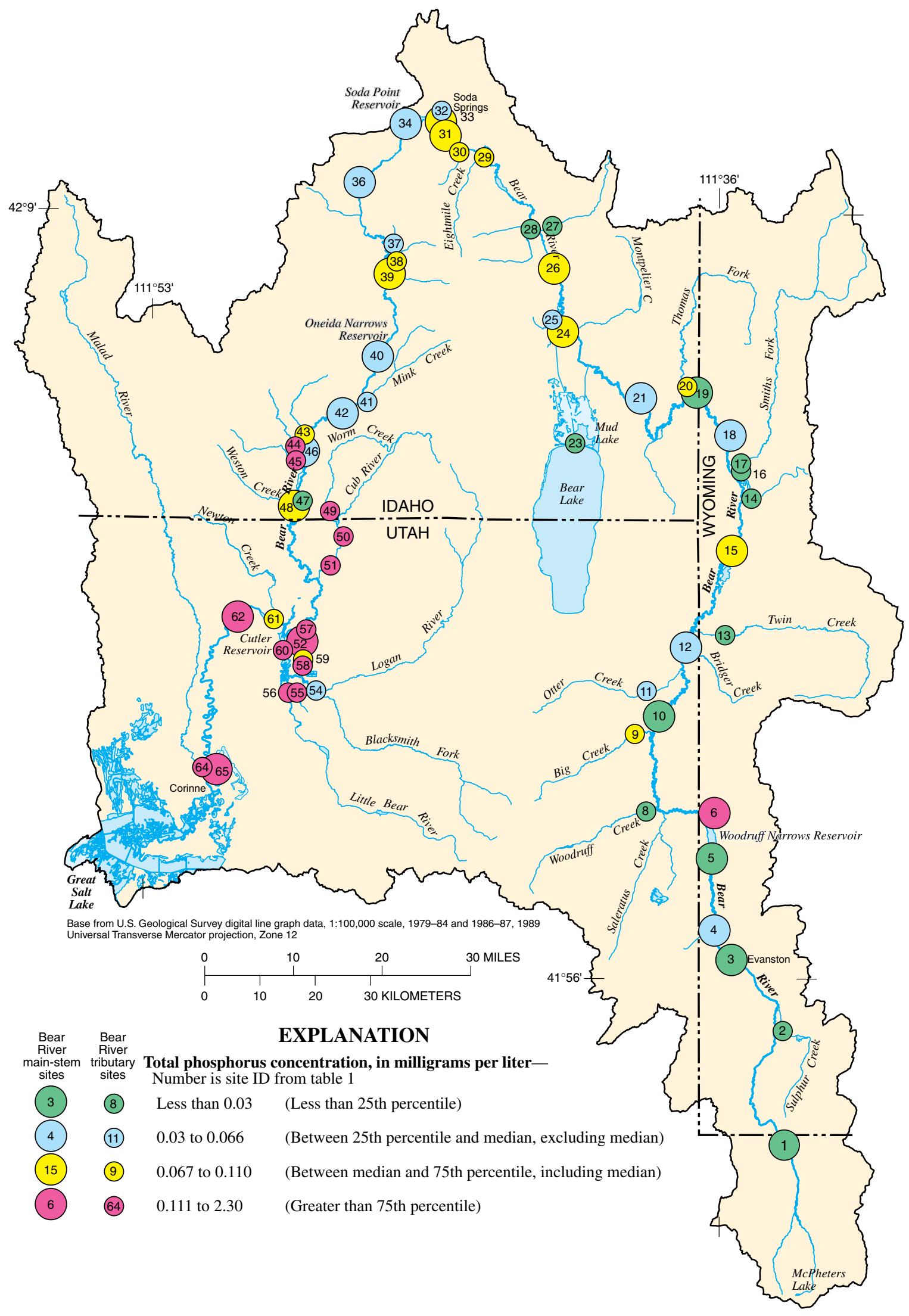

Figure 22. Concentration of total phosphorus in water samples collected from selected sites in the Bear River basin, July-August 2001. 


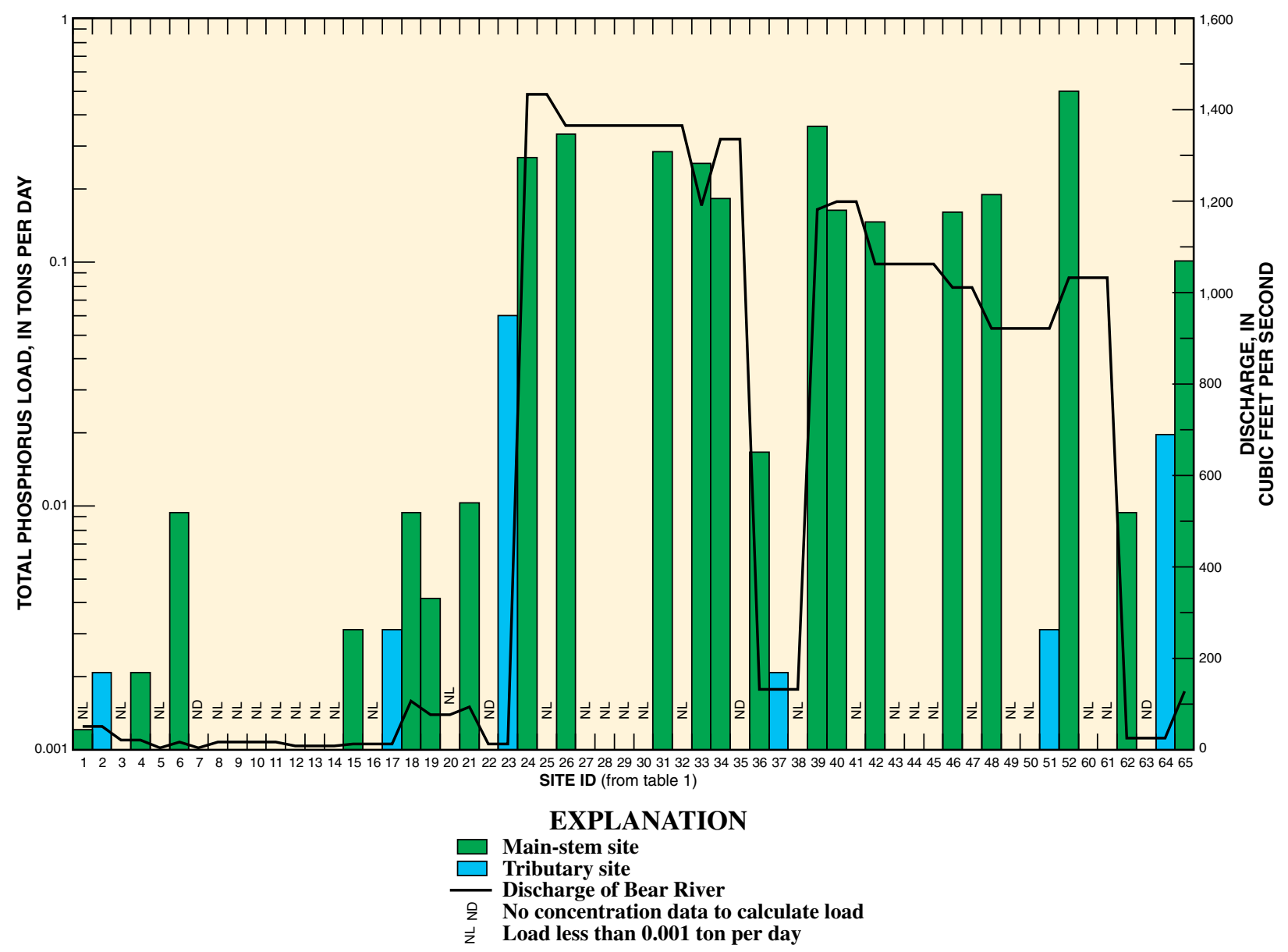

Figure 23. Total phosphorus load calculated from water samples collected from selected sites in the Bear River basin, July-August 2001.

pattern (for example, upstream to downstream) was evident on the basis of general deterioration or improvement in causal factors. CHL A concentrations in the Bear River generally were highest (above the $75^{\text {th }}$ percentile) below reservoirs but also were high $\left(290 \mathrm{mg} / \mathrm{m}^{2}\right)$ at site 18 , below the Smiths Fork confluence (fig. 24).

A periphyton CHL A concentration of about $44 \mathrm{mg} / \mathrm{m}^{2}$ is one estimate of the background condition for streams in Aggregate Nutrient Ecoregion III (U.S. Environmental Protection Agency, 2000b). Four sites in the Bear River basin had concentrations of CHL A of less than $45 \mathrm{mg} / \mathrm{m}^{2}$, indicating that these sites had an abundance of algae consistent with natural conditions. Samples from 8 of the 14 sites where periphyton was collected had concentrations of CHL A that exceeded $100 \mathrm{mg} / \mathrm{m}^{2}$ (table 13). Concentrations of CHL A between 100 and $200 \mathrm{mg} / \mathrm{m}^{2}$ may be indicative of nuisance algal conditions (U.S. Environmental Protection Agency, 2000a). Algae at these sites may contribute to large nighttime decreases in dissolved-oxygen concentration, clogged filters or intakes, or degraded recreational or aesthetic uses.

\section{Summary and Conclusions}

This study was implemented to help provide a spatial snapshot of selected water-quality parameters in the Bear River basin during two base-flow periods in 2001: in March, prior to snowmelt runoff and in July-August, following snowmelt runoff. This second period coincides with the irrigation season in the Bear River basin, and flows in many segments of the river are augmented by releases of stored water or reduced by irrigation withdrawals, both of which affect the water quality of streams in the drainage basin. Water-quality samples were collected at 65 sites on the Bear River and selected tributaries from near the Utah-Wyoming Stateline south of Evanston, Wyoming, downstream to Corinne, Utah, near the outflow to Great Salt Lake. Samples were analyzed for dissolved solids and major ions, suspended sediment, nutrients, pesticides, and periphyton chlorophyll $a$.

On the main stem of the Bear River during March, concentrations of dissolved solids ranged from $116 \mathrm{mg} / \mathrm{L}$ near the Utah-Wyoming Stateline to $672 \mathrm{mg} / \mathrm{L}$ near Corinne. Dissolved-solids concentrations in the Bear River downstream 


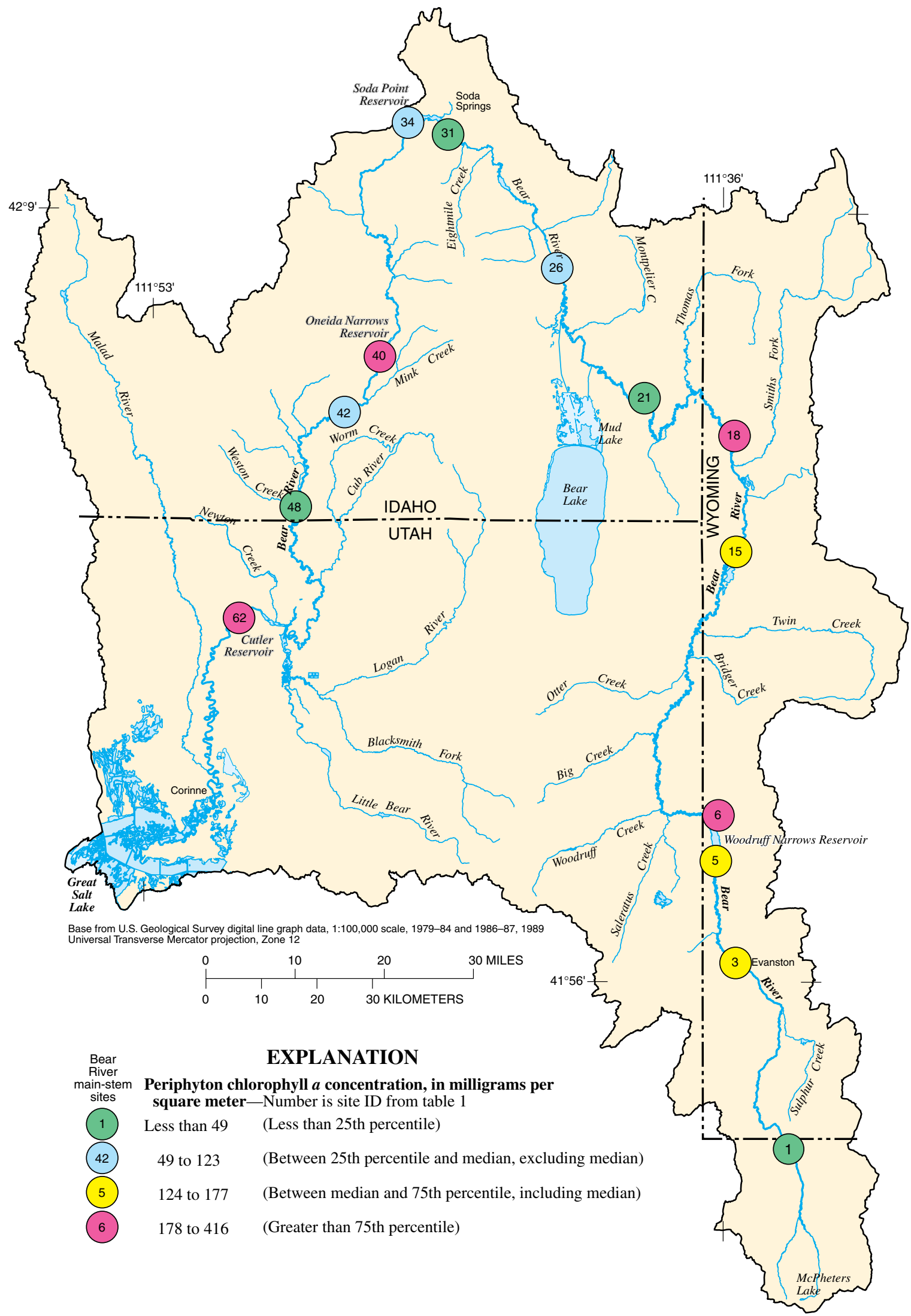

Figure 24. Concentration of chlorophyll $a$ in periphyton (algae) samples collected from selected sites in the Bear River basin, August 2001. 
from Soda Springs, Idaho, generally were higher than in the river upstream from this area. During July-August, concentrations of dissolved solids ranged from $117 \mathrm{mg} / \mathrm{L}$ near the Utah-Wyoming Stateline to $2,540 \mathrm{mg} / \mathrm{L}$ near Corinne and were heavily influenced by outflow from irrigation diversions. High concentrations of dissolved solids and loads in the Bear River below Cutler Reservoir result largely from inflow of mineralized ground water and in the vicinity of Corinne were high enough to exceed the Utah standard for agriculture during the July-August sampling period.

Suspended-sediment concentrations in the Bear River in March ranged from $2 \mathrm{mg} / \mathrm{L}$ below Woodruff Narrows Reservoir to $98 \mathrm{mg} / \mathrm{L}$ near Preston, Idaho, with a median concentration of $28 \mathrm{mg} / \mathrm{L}$. Tributary concentrations generally were higher, as much as $861 \mathrm{mg} / \mathrm{L}$ in water from Battle Creek. The largest suspended-sediment loads to the Bear River in March were contributed by the Little Bear River, and the largest loads to the river in July-August were contributed by the Bear Lake Outlet Canal. Sediment concentrations in sampled tributary basins in July-August generally were lower than in March. Streams with sediment concentrations high enough to increase concentrations in the main stem downstream from their confluences included Whiskey Creek, Otter Creek, Trout Creek, and the Malad River. Suspended-sediment concentrations in the Bear River generally decrease below reservoirs.

Dissolved ammonia concentrations in the Bear River and its tributaries in March ranged from less than $0.021 \mathrm{mg} / \mathrm{L}$ to as much as $1.43 \mathrm{mg} / \mathrm{L}$. The dissolved ammonia concentration in Spring Creek exceeded the EPA chronic criterion of $1.09 \mathrm{mg} / \mathrm{L}$ and the dissolved ammonia plus organic nitrogen concentration in the creek was $2.4 \mathrm{mg} / \mathrm{L}$. Spring Creek is the only site where concentrations of all ammonia species exceeded 1.0 $\mathrm{mg} / \mathrm{L}$. Dissolved ammonia and ammonia plus organic nitrogen concentrations in the Bear River basin in July-August were considerably lower than in March.

The concentrations of most dissolved and suspended forms of nitrogen generally were higher in March than in July-August. The median nitrite plus nitrate concentration in water samples collected from all sites in July-August (0.041 $\mathrm{mg} / \mathrm{L}$ ) was less than one-tenth of the median for all March water samples $(0.526 \mathrm{mg} / \mathrm{L})$. In samples collected during March, tributary concentrations of dissolved nitrite plus nitrate ranged from $0.042 \mathrm{mg} / \mathrm{L}$ (estimated) to $5.28 \mathrm{mg} / \mathrm{L}$. In samples collected during July-August from tributaries, concentrations ranged from less than $0.023 \mathrm{mg} / \mathrm{L}$ to $3.06 \mathrm{mg} / \mathrm{L}$. Concentrations of nitrite plus nitrate were highest in the Whiskey Creek and Spring Creek drainage basins and at main-stem sites below Cutler Reservoir near Collinston (March) and Corinne (July-August).

Concentrations of total phosphorus at main-stem sites were fairly similar during both base-flow periods, ranging from less than 0.02 to $0.49 \mathrm{mg} / \mathrm{L}$ during March and less than 0.02 to $0.287 \mathrm{mg} / \mathrm{L}$ during July-August. In March, concentrations of total phosphorus in the Bear River generally increased from upstream to downstream. Total phosphorus concentrations in tributaries generally were higher in March than in
July-August. During July-August, inflow from the Bear Lake Outlet Canal substantially increased total phosphorus loads in the Bear River downstream from Bear Lake.

Pesticides were detected at 20 sites sampled either in March or July-August, but concentrations were less than 0.1 $\mu \mathrm{g} / \mathrm{L}$. The most frequently detected insecticide was malathion, and prometon and atrazine were the most frequently detected herbicides. Concentrations of the 12 pesticides detected did not exceed established aquatic-life guidelines and were not a threat to aquatic life in the Bear River during the study periods. In addition, pesticide concentrations in water samples collected from Bear River basin sites were at least two orders of magnitude less than EPA established human-health standards.

Periphyton samples were collected at 14 sites on the Bear River during August. Chlorophyll $a$ concentrations ranged from $21 \mathrm{mg} / \mathrm{m}^{2}$ near the Utah-Wyoming Stateline to 416 $\mathrm{mg} / \mathrm{m}^{2}$ in the Bear River below Oneida Narrows Reservoir, with the highest concentrations occurring below reservoirs. Samples from 8 of the 14 sites had concentrations of chlorophyll $a$ that exceeded $100 \mathrm{mg} / \mathrm{m}^{2}$, indicating that algal abundance at these sites may represent a nuisance condition.

Additional basin-wide synoptic studies in the Bear River basin, particularly during peak periods of snowmelt runoff, would help to give a more complete picture of water quality in the basin. These studies provide valuable data that allow managers to evaluate the effects of adjoining management areas on areas they are responsible for, as well as the effects of their decisions on adjoining areas.

\section{References Cited}

Anderson, J.R., Hardy, E.E., Roach, J.T., and Witmer, R.E., 1976, A land use and land cover classification system for use with remote sensor data: U.S. Geological Survey Professional Paper 964, 28 p.

Baskin, R.L., Waddell, K.M., Thiros, S.A., Giddings, E.M., Hadley, H.K., Stephens, D.W., and Gerner, S.J., 2002, Water-quality assessment of the Great Salt Lake Basins, Utah, Idaho, and Wyoming-Environmental setting and study design: U.S. Geological Survey Water-Resources Investigations Report 02-4115, 47 p.

Bouchard, D.P., Kaufman, D.S., Hochberg, A., and Quade, J., 1998, Quaternary history of the Thatcher Basin, Idaho, reconstructed from the ${ }^{87} \mathrm{Sr} /{ }^{86} \mathrm{Sr}$ and amino acid composition of lacustrine fossils: Implications for the diversion of the Bear River into the Bonneville Basin: Palaeogeography, Palaeoclimatology, Palaeoecology, v. 141 (1-2), p. 95-114.

Canadian Council of Ministers of the Environment, 2001, Canadian water quality guidelines for the protection of aquatic life - Summary table (Chapter 4), in Canadian Environmental Quality Guidelines, accessed January 16, 2003, at http://www.ccme.ca/publications/ceqg_rcqe.html 
Eldridge, A., 2002, Nitrate in drinking water, State of Oregon Department of Enrivonmental Quality Fact Sheet, accessed November 2006, at http://www.deq.state.or.us/wq/pubs/ factsheets/groundwater/nitratedw.pdf

Gerner, S.J., 2003, Water quality at fixed sites in the Great Salt Lake Basins, Utah, Idaho, and Wyoming, water years 1999 - 2000: U.S. Geological Survey Water-Resources Investigations Report 03-4236, 56 p.

Gilliom, R.J., Alley, W.M., and Gurtz, M.E., 1995, Design of the National Water-Quality Assessment Program: Occurrence and distribution of water-quality conditions: U.S. Geological Survey Circular 1112, 33 p.

Herbert, L.R., Wilberg, D.E., and Tibbetts, J.R., 2002, Water Resources Data, Utah, Water Year 2001: U.S. Geological Survey Water-Data Reports UT-01-1, 440 p.

Horowitz, A.J., Demas, C.R., Fitzgerald, K.K., Miller, T.L., and Rickert, D.A., 1994, U.S. Geological Survey protocol for the collection and processing of surface-water samples for the subsequent determination of inorganic constituents in filtered water: U.S. Geological Survey Open-File Report 94-539, $57 \mathrm{p}$.

Idaho Department of Environmental Quality, 2003, Water quality standards and wastewater treatment requirements, IDAPA 58.01.02, accessed January 11, 2006, at http://adm. idaho.gov/adminrules/rules/idapa58/0102.pdf

Idaho Department of Environmental Quality, 2005, Bear River/Malad Subbasin assessment and total maximum daily load plan, prepared by Ecosystems Research Institute, Inc., Logan, Utah, accessed January 11, 2006, at http://www.deq. state.id.us/water/data_reports/surface_water/tmdls/bear_ river/bear_river_chaptl.pdf

Multi-Resolution Land Characteristics Consortium, 1992, National Land Cover Data, accessed October 2003, at http://www.epa.gov/mrlc/nlcd.html

Mundorff, J.C., 1970, Major thermal springs of Utah: Utah Geological and Mineralogical Survey, Water-Resources Bulletin 13, $60 \mathrm{p}$.

Ott, R.L., and Longnecker, M., 2001, An introduction to statistical methods and data analysis (5th ed.): Pacific Grove, California, Duxbury, 1152 p.

Paul, M.J., and Meyer, J.L., 2001, Streams in the urban landscape: Annual Review of Ecology and Systematics, 2001, v. 32, p. 333-364.

Porter, S.D., Cuffney, T.F., Gurtz, M.E., Meador, M.R., 1993, Methods for collecting algal samples as part of the National Water-Quality Assessment Program: U.S. Geological Survey Open-File Report 93-409, 39 p.
Shelton, L.R., 1994, Field guide for collecting and processing stream-water samples for the National Water-Quality Assessment Program: U.S. Geological Survey Open-File Report 94-455, 42 p.

U.S. Environmental Protection Agency, 1999, Update of ambient water quality criteria for ammonia: U.S. Environmental Protection Agency Report EPA-822-R-99-014, accessed May 29, 2002, at http://www.epa.gov/waterscience/ standards/ammonia/99update.pdf

U.S. Environmental Protection Agency, 2000a, Nutrient criteria technical guidance manual: Rivers and streams: U.S. Environmental Protection Agency Report EPA 822-B-00002, accessed October 2, 2003, at http://www.epa.gov/ waterscience/criteria/nutrient/guidance/rivers/index.html

U.S. Environmental Protection Agency, 2000b, Ambient water quality criteria recommendations - Information supporting the development of State and Tribal nutrient criteria for rivers and streams in Nutrient Ecoregion III: U.S. Environmental Protection Agency Report EPA 822-B-00-016, accessed October 2, 2003, at http://www.epa.gov/waterscience/criteria/nutrient/ecoregions/rivers/rivers_3.pdf

U.S. Environmental Protection Agency, 2002, National recommended water quality criteria - 2002: U.S. Environmental Protection Agency Report EPA-822-R-02-047, accessed October 2, 2003, at http://www.epa.gov/waterscience/criteria/nrwqc-2002.pdf

U.S. Environmental Protection Agency, 2004, 2004 edition of the drinking water standards and health advisories: U.S. Environmental Protection Agency Report EPA-822-R-04005, accessed July 21, 2006, at http://www.epa.gov/waterscience/criteria/drinking/standards/dwstandards.pdf

U.S. Geological Survey, 1999, The quality of our Nation's waters-Nutrients and pesticides: U.S. Geological Survey Circular 1225, 82 p.

Utah Division of Administrative Rules, 2005, Utah Administrative Code R317-2, Standards of quality for waters of the State, accessed January 11, 2006, at http://www.rules.utah. gov/publicat/code/r317/r317-002.htm

Utah Division of Water Quality, 2004, Utah's 2004 303(d) list of impaired waters, accessed January 10, 2006, at http://www.waterquality.utah.gov/documents/ 2004303dlistFinalall-11-04-04.pdf

Waddell, K.M., and Barton, J.D., 1980, Estimated inflow and evaporation for Great Salt Lake, Utah, 1931-76, with revised model for evaluating the effects of dikes on the water and salt balance of the lake: Utah Department of Natural Resources, Division of Water Resources Cooperative Investigation Report Number 20, 57 p. 
Waddell, K.M., Gerner, S.J., Thiros, S.A., Giddings, E.M., Baskin, R.L., Cederberg, J.R., and Albano, C.M., 2004, Water quality in the Great Salt Lake Basins, Utah, Idaho, and Wyoming, 1998 - 2001: U.S. Geological Survey Circular 1236, $36 \mathrm{p}$.

Waddell, K.M., and Giddings, E.M., 2003, Trace elements and organic compounds in sediment and fish tissue from the Great Salt Lake Basins, Utah, Idaho, and Wyoming, 1998 - 99: U.S. Geological Survey Water-Resources Investigations Report 03-4283, 45 p.

Waddell, K.M. and Price, Don, 1972, Quality of surface water in the Bear River basin, Utah, Wyoming, and Idaho: U.S. Geological Survey Hydrologic Investigations Atlas HA-417, 2 sheets, scale 1:500,000.

Wyoming Department of Environmental Quality, 2001, Wyoming surface water quality standards, Chapter 1 , accessed January 11, 2006, at http://deq.state.wy.us/wqd/WQDrules/ Chapter_01.pdf

Wyoming Department of Environmental Quality, 2004, Wyoming 2004 305(b) report, 2004 303(d) list of waters requiring TMDLs, accessed January 10, 2006, at http://deq.state. wy.us/wqd/watershed/downloads/305b/303d_2004.pdf 


\section{Tables}

Table 1. Location of sites sampled on the Bear River and its tributaries, March and July-August 2001

[Site designation: UT, Utah; ID, Idaho; WY, Wyoming; Site type: MS, main stem; T, tributary; Latitude and Longitude: dd, degrees; mm, minutes; ss, seconds; River miles: Miles downstream from headwaters at McPheters Lake; —, not applicable]

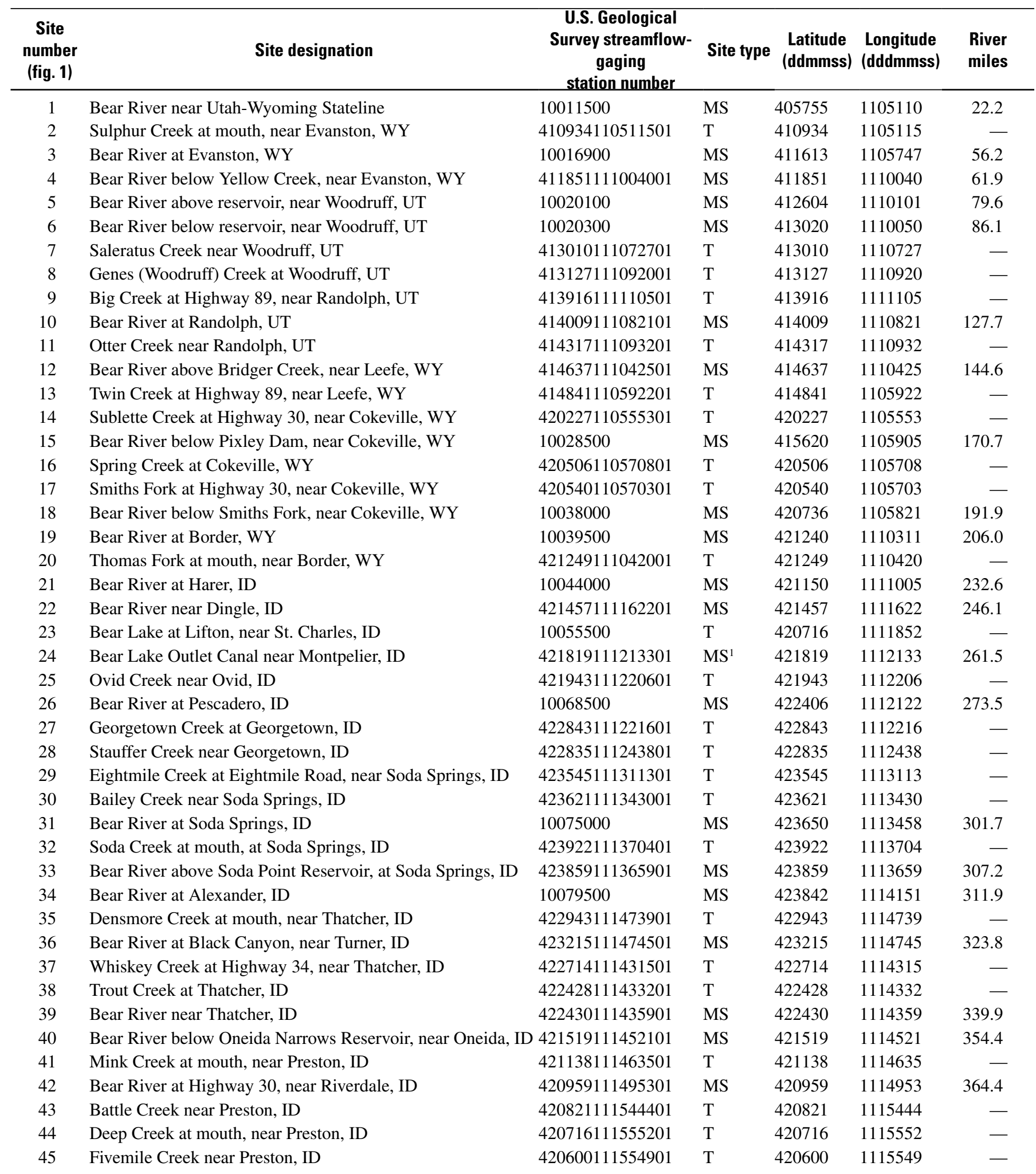


Table 1. Location of sites sampled on the Bear River and its tributaries, March and July-August 2001—Continued

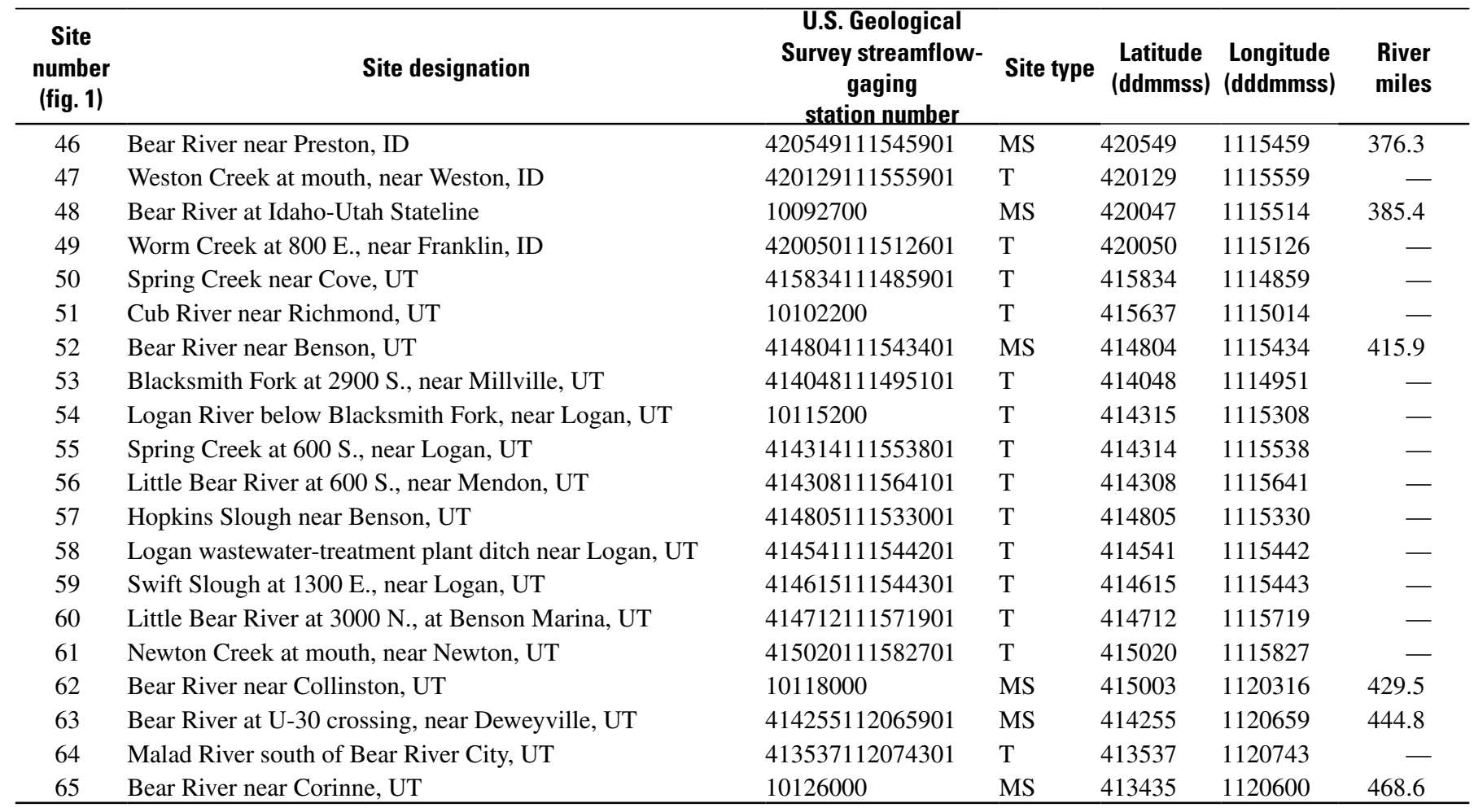

${ }^{1}$ Bear Lake Outlet Canal considered main-stem site because Bear River is diverted from main channel upstream from confluence of outlet canal with main channel. 
Table 2. Drainage area and land use/cover in the Bear River basin above sites sampled on the Bear River, March and July-August 2001 [Site designation: UT, Utah; ID, Idaho; WY, Wyoming; <, less than]

\begin{tabular}{|c|c|c|c|c|c|c|c|c|c|c|c|}
\hline \multirow{2}{*}{$\begin{array}{c}\text { Site } \\
\text { number } \\
\text { (fig. 1) }\end{array}$} & \multirow[b]{2}{*}{ Site designation } & \multirow{2}{*}{$\begin{array}{c}\text { Drain- } \\
\text { age area } \\
\text { (square } \\
\text { miles) }\end{array}$} & \multicolumn{8}{|c|}{ Land use/cover by basin (percent) } & \multirow{2}{*}{$\begin{array}{l}\text { Irrigated } \\
\text { land } \\
\text { (acres) }\end{array}$} \\
\hline & & & $\begin{array}{l}\text { Range- } \\
\text { land }\end{array}$ & Forest & $\begin{array}{l}\text { Agricul- } \\
\text { ture }\end{array}$ & Urban & Wetland & $\begin{array}{l}\text { Open } \\
\text { water }\end{array}$ & $\begin{array}{l}\text { Perennial } \\
\text { ice/snow }\end{array}$ & $\begin{array}{l}\text { Barren } \\
\text { land }\end{array}$ & \\
\hline 1 & $\begin{array}{l}\text { Bear River near Utah-Wyoming } \\
\text { Stateline }\end{array}$ & 172 & 26 & 67 & $<0.1$ & $<0.1$ & $<0.1$ & 0.2 & 0.7 & 5.4 & 30 \\
\hline 3 & Bear River at Evanston, WY & 442 & 43 & 45 & 8.9 & .2 & .9 & .3 & .3 & 2.2 & 29,370 \\
\hline 4 & $\begin{array}{l}\text { Bear River below Yellow Creek, } \\
\text { near Evanston, WY }\end{array}$ & 696 & 58 & 32 & 6.2 & .4 & 1.2 & .3 & .2 & 1.4 & 35,528 \\
\hline 5 & $\begin{array}{l}\text { Bear River above reservoir, near } \\
\text { Woodruff, UT }\end{array}$ & 754 & 60 & 30 & 6.7 & .4 & 1.1 & .3 & .2 & 1.3 & 40,900 \\
\hline 6 & $\begin{array}{l}\text { Bear River below reservoir, near } \\
\text { Woodruff, UT }\end{array}$ & 787 & 61 & 29 & 6.5 & .4 & 1.1 & .7 & .2 & 1.2 & 41,573 \\
\hline 10 & Bear River at Randolph, UT & 1,381 & 71 & 19 & 7.0 & .2 & 1.3 & .6 & .1 & .7 & 62,762 \\
\hline 12 & $\begin{array}{l}\text { Bear River above Bridger Creek, } \\
\text { near Leefe, WY }\end{array}$ & 1,515 & 71 & 18 & 8.2 & .2 & 1.5 & .6 & $<.1$ & .6 & 79,698 \\
\hline 15 & $\begin{array}{l}\text { Bear River below Pixley Dam, } \\
\text { near Cokeville, WY }\end{array}$ & 2,013 & 75 & 14 & 7.5 & .2 & 1.6 & .5 & $<.1$ & .7 & 88,525 \\
\hline 18 & $\begin{array}{l}\text { Bear River below Smiths Fork, } \\
\text { near Cokeville, WY }\end{array}$ & 2,444 & 75 & 15 & 6.8 & .2 & 1.9 & .5 & $<.1$ & .6 & 104,223 \\
\hline 19 & Bear River at Border, WY & 2,478 & 75 & 15 & 6.9 & .2 & 2.0 & .5 & $<.1$ & .5 & 107,940 \\
\hline 21 & Bear River at Harer, ID & 2,828 & 75 & 15 & 7.0 & .2 & 2.2 & .6 & $<.1$ & .5 & 132,788 \\
\hline 22 & Bear River near Dingle, ID & 2,861 & 75 & 15 & 7.2 & .2 & 2.2 & .6 & $<.1$ & .5 & 134,871 \\
\hline 26 & Bear River at Pescadero, ID & 3,699 & 70 & 15 & 8.3 & .2 & 3.0 & 3.9 & $<.1$ & .4 & 201,053 \\
\hline 31 & Bear River at Soda Springs, ID & 3,967 & 68 & 16 & 9.2 & .2 & 2.9 & 3.6 & $<.1$ & .3 & 212,105 \\
\hline 33 & $\begin{array}{l}\text { Bear River above Soda Point } \\
\text { Reservoir, at Soda Springs, ID }\end{array}$ & 4,029 & 67 & 16 & 9.7 & .2 & 2.8 & 3.6 & $<.1$ & .3 & 213,339 \\
\hline 34 & Bear River at Alexander, ID & 4,089 & 67 & 16 & 10 & .2 & 2.8 & 3.6 & $<.1$ & .3 & 215,660 \\
\hline 36 & $\begin{array}{l}\text { Bear River at Black Canyon, } \\
\text { near Turner, ID }\end{array}$ & 4,114 & 67 & 16 & 11 & .2 & 2.8 & 3.6 & $<.1$ & .3 & 220,421 \\
\hline 39 & Bear River near Thatcher, ID & 4,257 & 66 & 16 & 12 & .2 & 2.7 & 3.5 & $<.1$ & .3 & 252,038 \\
\hline 40 & $\begin{array}{l}\text { Bear River below Oneida Reser- } \\
\text { voir, near Oneida, ID }\end{array}$ & 4,454 & 65 & 16 & 12 & .2 & 2.7 & 3.3 & $<.1$ & .3 & 261,445 \\
\hline 42 & $\begin{array}{l}\text { Bear River at Highway 30, near } \\
\text { Riverdale, ID }\end{array}$ & 4,543 & 65 & 17 & 12 & .2 & 2.6 & 3.3 & $<.1$ & .3 & 265,092 \\
\hline 46 & Bear River near Preston, ID & 4,775 & 64 & 16 & 14 & .2 & 2.5 & 3.1 & $<.1$ & .3 & 290,815 \\
\hline 48 & $\begin{array}{l}\text { Bear River at Idaho-Utah } \\
\text { Stateline }\end{array}$ & 4,881 & 64 & 16 & 15 & .2 & 2.5 & 3.1 & $<.1$ & .3 & 305,416 \\
\hline 52 & Bear River near Benson UT & 5,218 & 62 & 16 & 16 & .2 & 2.5 & 3.0 & $<.1$ & .3 & 373,935 \\
\hline 62 & Bear River near Collinston, UT & 6,266 & 61 & 17 & 17 & .4 & 2.3 & 2.6 & $<.1$ & .2 & 450,992 \\
\hline 63 & $\begin{array}{l}\text { Bear River at U-30 crossing, } \\
\text { near Deweyville, UT }\end{array}$ & 6,304 & 61 & 17 & 17 & .4 & 2.3 & 2.6 & $<.1$ & .2 & 456,061 \\
\hline 65 & Bear River near Corinne, UT & 7,065 & 61 & 16 & 18 & .4 & 2.1 & 2.4 & $<.1$ & .2 & 552,762 \\
\hline
\end{tabular}


Table 3. List of impaired water bodies in the Bear River basin, 2004-05

[HUC, Hydrologic Unit Code; Data from Utah Division of Water Quality (2004); Wyoming Department of Environmental Quality (2004); Idaho Department of Environmental Quality (2005)]

\begin{tabular}{|c|c|c|c|c|}
\hline Site & Description & HUC & State & Impairment \\
\hline Bear River & From Woodruff Creek to Utah/Wyoming border & 16010101 & Utah & Dissolved oxygen \\
\hline Bear River & From Utah/Wyoming border to Woodruff Creek & 16010101 & Utah & Dissolved oxygen \\
\hline Newton Reservoir & - & 16010202 & Utah & Dissolved oxygen, total phosphorus \\
\hline Cutler Reservoir & - & 16010202 & Utah & Dissolved oxygen, total phosphorus \\
\hline Tony Grove Lake & - & 16010203 & Utah & $\begin{array}{l}\text { Dissolved oxygen, total phosphorus, } \\
\text { pH }\end{array}$ \\
\hline Mantua Reservoir & - & 16010204 & Utah & Temperature \\
\hline Bridger Creek & From Utah Stateline upstream & 16010101 & Wyoming & Habitat degradation \\
\hline Bear River & From Sulphur Creek to Woodruff Narrows Reservoir & 16010101 & Wyoming & Sediment \\
\hline Dry Creek & Headwaters to Thomas Fork & 16010102 & Idaho & Nutrients, sediment \\
\hline Thomas Fork & Idaho/Wyoming border to Bear River & 16010102 & Idaho & Nutrients, sediment \\
\hline Co-op Creek & Source to Stauffer Creek & 16010201 & Idaho & Nutrients, sediment \\
\hline Pearl Creek & North Fork to Bear River & 16010201 & Idaho & Nutrients, sediment \\
\hline Alexander Reservoir & - & 16010201 & Idaho & Sediment \\
\hline Meadow Creek & Headwaters to North Creek & 16010201 & Idaho & Sediment, unknown metals \\
\hline Ovid Creek & Confluence of North and Mill Creeks to Bear River & 16010201 & Idaho & Sediment \\
\hline Snowslide Canyon & Source to Montpelier Creek & 16010201 & Idaho & Sediment \\
\hline St. Charles Creek & Source to refuge & 16010201 & Idaho & Nutrients, sediment \\
\hline North Creek & Below Mill Hollow to Ovid Creek & 16010201 & Idaho & Unknown $^{1}$ \\
\hline Battle Creek & Source to Bear River & 16010202 & Idaho & Nutrients, sediment \\
\hline Cub River & Sugar Creek to Idaho/Utah border & 16010202 & Idaho & Nutrients, sediment, flow alteration \\
\hline Densmore Creek & Source to Bear River & 16010202 & Idaho & Nutrients, sediment \\
\hline Maple Creek & Left Fork to Cub River & 16010202 & Idaho & Bacteria, Unknown ${ }^{1}$ \\
\hline Fivemile Creek & Source to Bear River & 16010202 & Idaho & Unknown $^{1}$ \\
\hline Bear River & Oneida Narrows Reservoir dam to Idaho/Utah border & 16010202 & Idaho & Nutrients, sediment, flow alteration \\
\hline Worm Creek & Glendale Reservoir to Idaho/Utah border & 16010202 & Idaho & Unknown $^{1}$ \\
\hline Elkhorn Creek & Source to Little Malad River & 16010202 & Idaho & Unknown $^{1}$ \\
\hline Bear River & Cove powerplant to Oneida Dam & 16010202 & Idaho & Nutrients, sediment, flow alteration \\
\hline Deep Creek & Oxford Slough to Bear River & 16010204 & Idaho & Unknown $^{1}$ \\
\hline Samaria Creek & Source to Malad River & 16010204 & Idaho & Nutrients, sediment \\
\hline Devil Creek & Devil Creek Reservoir dam to Malad River & 16010204 & Idaho & Nutrients, sediment \\
\hline Malad River & Source to Pleasant View & 16010204 & Idaho & Sediment \\
\hline Wright Creek & Source to Daniels Reservoir & 16010204 & Idaho & Sediment \\
\hline Dairy Creek & Source to Wright Creek & 16010204 & Idaho & Unknown $^{1}$ \\
\hline Little Malad River & Headwaters to Malad River & 16010204 & Idaho & Sediment \\
\hline Deep Creek & Headwaters to mouth & 16010204 & Idaho & Unknown $^{1}$ \\
\hline
\end{tabular}

${ }^{1}$ Unknown: Site added in 1998; data not sufficient for load analysis (additional sites and/or more sampling events needed); nutrient and sediment impairments identified; possible pollutant sources include agriculture, livestock grazing, and streambank erosion. 
Table 4. Water bodies in the Bear River basin with associated Total Maximum Daily Load (TMDL) documents

\begin{tabular}{|c|c|c|c|}
\hline Site & State & Impairment & $\begin{array}{c}\text { TMDL } \\
\text { Established }\end{array}$ \\
\hline Middle Bear River & Utah & Total phosphorus & 1997 \\
\hline Cutler Reservoir & Utah & Ammonia & 1998 \\
\hline Yellow Creek & Wyoming & $\begin{array}{l}\text { Ammonia } \\
\text { Fecal-coliform bacteria } \\
\text { Total residual chlorine }\end{array}$ & 1999 \\
\hline Central Bear River & Wyoming & $\begin{array}{l}\text { Fecal-coliform bacteria } \\
\text { Total residual chlorine }\end{array}$ & 1999 \\
\hline Lower Bear River & Utah & Total phosphorus & 2002 \\
\hline Little Bear River & Utah & $\begin{array}{l}\text { Total phosphorus } \\
\text { Hydrologic modification }\end{array}$ & 2000 \\
\hline Mantua Reservoir & Utah & $\begin{array}{l}\text { Total phosphorus } \\
\text { Dissolved oxygen } \\
\text { pH }\end{array}$ & 2000 \\
\hline Spring Creek & Utah & $\begin{array}{l}\text { Total phosphorus } \\
\text { Dissolved oxygen } \\
\text { Ammonia } \\
\text { Fecal-coliform bacteria }\end{array}$ & 2002 \\
\hline Hyrum Reservoir & Utah & $\begin{array}{l}\text { Total phosphorus } \\
\text { Dissolved oxygen } \\
\text { Fecal-coliform bacteria }\end{array}$ & 2002 \\
\hline
\end{tabular}


Table 5. Discharge, dissolved-oxygen concentration, and physical properties for water samples collected from selected sites on the Bear River and its tributaries, March and July-August 2001

[Site designation: UT, Utah; ID, Idaho; WY, Wyoming; Site type: MS, main stem; T, tributary; $\mathrm{ft}^{3} / \mathrm{s}$, cubic feet per second; mg/L, milligrams per liter; $\mu \mathrm{S} / \mathrm{cm}$, microsiemens per centimeter at 25 degrees Celsius; ${ }^{\circ} \mathrm{C}$, degrees Celsius; —, no data]

\begin{tabular}{|c|c|c|c|c|c|c|c|c|c|c|c|}
\hline $\begin{array}{c}\text { Site } \\
\text { number } \\
\text { (fig. 1) }\end{array}$ & Site designation & $\begin{array}{l}\text { Site } \\
\text { type }\end{array}$ & Date & Time & $\begin{array}{c}\text { Dis- } \\
\text { charge, } \\
\text { instan- } \\
\text { taneous } \\
\left(\mathrm{ft}^{3} / \mathbf{s}\right)\end{array}$ & $\begin{array}{c}\text { Dis- } \\
\text { solved } \\
\text { oxygen } \\
\text { (mg/L) }\end{array}$ & $\begin{array}{c}\text { Dis- } \\
\text { solved } \\
\text { oxygen } \\
\text { (percent } \\
\text { saturation) }\end{array}$ & $\begin{array}{c}\text { pH, } \\
\text { field } \\
\text { (standard } \\
\text { units) }\end{array}$ & $\begin{array}{c}\text { Specific } \\
\text { conduct- } \\
\text { ance, } \\
\text { lab } \\
\text { ( } \mathrm{HS} / \mathrm{cm})\end{array}$ & $\begin{array}{c}\text { Specific } \\
\text { conduct- } \\
\text { ance, } \\
\text { field } \\
\text { ( } \mathrm{SS} / \mathrm{cm})\end{array}$ & $\begin{array}{c}\text { Temper- } \\
\text { ature } \\
\left({ }^{\circ} \mathrm{C}\right)\end{array}$ \\
\hline \multirow[t]{2}{*}{1} & \multirow{2}{*}{$\begin{array}{l}\text { Bear River near Utah-Wyoming } \\
\text { Stateline }\end{array}$} & MS & $03-20-01$ & 1030 & 37 & 10.5 & 104 & 8.4 & - & 210 & 2.4 \\
\hline & & & 08-09-01 & 1100 & 52 & 7.7 & 104 & 8.5 & - & 183 & 16.1 \\
\hline \multirow[t]{2}{*}{2} & \multirow{2}{*}{$\begin{array}{l}\text { Sulphur Creek at mouth, near } \\
\text { Evanston, WY }\end{array}$} & $\mathrm{T}$ & 03-20-01 & 1300 & 6.8 & 10.0 & 92 & 8.2 & - & 554 & 1.0 \\
\hline & & & 08-09-01 & 0850 & 28 & 7.7 & 101 & 8.4 & - & 498 & 16.5 \\
\hline \multirow[t]{2}{*}{3} & \multirow[t]{2}{*}{ Bear River at Evanston, WY } & MS & $03-21-01$ & 0950 & 86 & 11.0 & 99 & 8.3 & - & 474 & .6 \\
\hline & & & 08-09-01 & 0900 & 19 & 8.6 & 112 & 8.3 & - & 458 & 16.6 \\
\hline \multirow[t]{2}{*}{4} & \multirow{2}{*}{$\begin{array}{l}\text { Bear River below Yellow Creek, } \\
\text { near Evanston, WY }\end{array}$} & MS & 03-21-01 & 0920 & 135 & 10.6 & 94 & 8.1 & - & 505 & .5 \\
\hline & & & 08-09-01 & 1140 & 20 & 8.6 & 127 & 8.3 & - & 490 & 19.0 \\
\hline \multirow[t]{2}{*}{5} & \multirow{2}{*}{$\begin{array}{l}\text { Bear River above reservoir, near } \\
\text { Woodruff, UT }\end{array}$} & MS & 03-20-01 & 1610 & 181 & 9.9 & 85 & 8.3 & - & 416 & .1 \\
\hline & & & 08-08-01 & 1430 & .52 & 11.8 & 177 & 8.8 & - & 635 & 23.9 \\
\hline \multirow[t]{2}{*}{6} & \multirow{2}{*}{$\begin{array}{l}\text { Bear River below reservoir, near } \\
\text { Woodruff, UT }\end{array}$} & MS & 03-20-01 & 1000 & 29 & 8.9 & 80 & 8.0 & - & 539 & 1.7 \\
\hline & & & 08-08-01 & 1100 & 22 & 5.2 & 76 & 8.5 & - & 538 & 21.8 \\
\hline 7 & $\begin{array}{l}\text { Saleratus Creek near Woodruff, } \\
\text { UT }\end{array}$ & $\mathrm{T}$ & 03-19-01 & 1520 & 2.9 & 7.5 & 65 & 8.2 & - & 1,150 & .3 \\
\hline \multirow[t]{2}{*}{8} & \multirow{2}{*}{$\begin{array}{l}\text { Genes (Woodruff) Creek at } \\
\text { Woodruff, UT }\end{array}$} & $\mathrm{T}$ & 03-19-01 & 1640 & .70 & 9.8 & 84 & 8.3 & - & 404 & .2 \\
\hline & & & 08-08-01 & 1410 & .24 & 7.1 & 104 & 8.4 & 475 & - & 22.7 \\
\hline \multirow[t]{2}{*}{9} & \multirow{2}{*}{$\begin{array}{l}\text { Big Creek at Highway 89, near } \\
\text { Randolph, UT }\end{array}$} & $\mathrm{T}$ & 03-19-01 & 1350 & 13 & 10.2 & 92 & 8.4 & - & 560 & 1.9 \\
\hline & & & 08-07-01 & 1520 & .19 & 11.9 & 180 & 9.7 & - & 417 & 25.3 \\
\hline \multirow[t]{2}{*}{10} & \multirow{2}{*}{ Bear River at Randolph, UT } & MS & 03-19-01 & 1350 & 58 & 11.0 & 117 & 8.3 & - & 777 & 8.2 \\
\hline & & & 08-08-01 & 1140 & 17 & 8.3 & 116 & 8.1 & - & 643 & 21.0 \\
\hline \multirow[t]{2}{*}{11} & \multirow[t]{2}{*}{ Otter Creek near Randolph, UT } & $\mathrm{T}$ & 03-19-01 & 1530 & 19 & 8.9 & 87 & 8.4 & - & 448 & 4.2 \\
\hline & & & 08-08-01 & 0930 & .23 & 7.3 & 94 & 8.2 & - & 514 & 17.0 \\
\hline \multirow[t]{2}{*}{12} & \multirow{2}{*}{$\begin{array}{l}\text { Bear River above Bridger Creek, } \\
\text { near Leefe, WY }\end{array}$} & MS & 03-19-01 & 1140 & 83 & 10.2 & 87 & 8.2 & - & 593 & .1 \\
\hline & & & 08-07-01 & 1230 & 5.0 & 9.4 & 141 & 8.2 & - & 830 & 24.9 \\
\hline 13 & Twin Creek at Highway 89, near & $\mathrm{T}$ & 03-18-01 & 1450 & 7.3 & 9.0 & 87 & 8.5 & - & 967 & 4.4 \\
\hline & Leefe & & $08-07-01$ & 0950 & 4.2 & 9.6 & 128 & 8.5 & - & 783 & 18.0 \\
\hline 14 & $\begin{array}{l}\text { Sublette Creek at Highway 30, } \\
\text { near Cokeville, WY }\end{array}$ & $\mathrm{T}$ & 08-07-01 & 0820 & .04 & 5.8 & 73 & 8.0 & - & 562 & 16.0 \\
\hline 15 & Bear River below Pixley Dam, & MS & 03-18-01 & 1400 & 7.0 & 11.5 & 100 & 8.3 & - & 589 & .7 \\
\hline & near $\mathrm{C}$ & & $08-06-01$ & 1600 & 13 & 4.6 & 77 & 8.4 & - & 943 & 24.0 \\
\hline 16 & Spring Creek at Cokeville, WY & $\mathrm{T}$ & 03-19-01 & 1020 & 14 & 10.9 & 105 & 8.3 & - & 498 & 4.3 \\
\hline & & & 08-07-01 & 1540 & 18 & 9.4 & 135 & 8.6 & - & 376 & 22.4 \\
\hline 17 & Smiths Fork at Highway 30, near & $\mathrm{T}$ & 03-18-01 & 1300 & 63 & 11.6 & 116 & 8.8 & - & 439 & 5.8 \\
\hline & $\mathrm{Col}$ & & $08-07-01$ & 1350 & 56 & 9.8 & 140 & 8.6 & - & 363 & 21.7 \\
\hline 18 & Bear River below Smiths Fork, & MS & $03-18-01$ & 1000 & 156 & 11.5 & 101 & 8.3 & - & 539 & 1.3 \\
\hline & nea & & $08-07-01$ & 0940 & 108 & 7.7 & 101 & 8.2 & - & 500 & 18.3 \\
\hline 19 & Bear River at Border, WY & MS & 03-18-01 & 1040 & 147 & 11.2 & 96 & 8.3 & - & 529 & .4 \\
\hline & & & $08-06-01$ & 1410 & 77 & 9.4 & 133 & 8.3 & - & 530 & 22.2 \\
\hline 20 & Thomas Fork at mouth, near & $\mathrm{T}$ & $03-17-01$ & 1440 & 17.5 & 11.8 & 122 & 8.1 & - & 860 & 7.2 \\
\hline & Borde & & $08-06-01$ & 1200 & .91 & 6.2 & 83 & 8.1 & - & 738 & 20.0 \\
\hline 21 & Bear River at Harer, ID & MS & $08-06-01$ & 1000 & 92 & 7.5 & 105 & 8.3 & - & 637 & 22.5 \\
\hline 22 & Bear River near Dingle, ID & & 03-17-01 & 1150 & 153 & 10.8 & 93 & 8.1 & - & 569 & .7 \\
\hline & & MS & $08-06-01$ & 1000 & 11 & 5.8 & 83 & 8.0 & - & 637 & 18.8 \\
\hline
\end{tabular}


Table 5. Discharge, dissolved-oxygen concentration, and physical properties for water samples collected from selected sites on the Bear River and its tributaries, March and July-August 2001—Continued

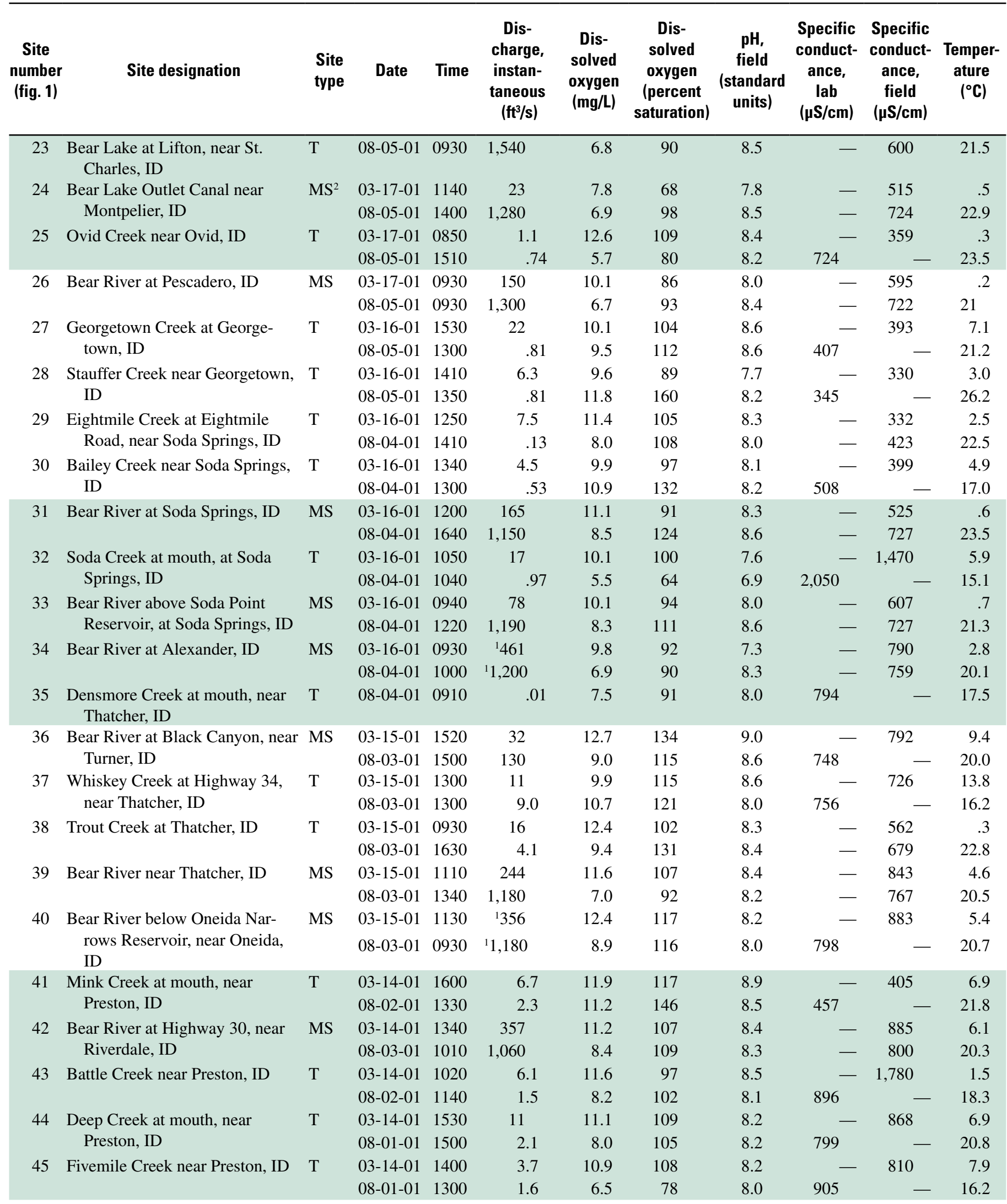


Table 5. Discharge, dissolved-oxygen concentration, and physical properties for water samples collected from selected sites on the Bear River and its tributaries, March and July-August 2001—Continued

\begin{tabular}{|c|c|c|c|c|c|c|c|c|c|c|c|}
\hline $\begin{array}{c}\text { Site } \\
\text { number } \\
\text { (fig. 1) }\end{array}$ & Site designation & $\begin{array}{l}\text { Site } \\
\text { type }\end{array}$ & Date & Time & $\begin{array}{c}\text { Dis- } \\
\text { charge, } \\
\text { instan- } \\
\text { taneous } \\
\left(\mathrm{ft}^{3} / \mathbf{s}\right)\end{array}$ & $\begin{array}{c}\text { Dis- } \\
\text { solved } \\
\text { oxygen } \\
(\mathrm{mg} / \mathrm{L})\end{array}$ & $\begin{array}{c}\text { Dis- } \\
\text { solved } \\
\text { oxygen } \\
\text { (percent } \\
\text { saturation) }\end{array}$ & $\begin{array}{c}\text { pH, } \\
\text { field } \\
\text { (standard } \\
\text { units) }\end{array}$ & $\begin{array}{c}\text { Specific } \\
\text { conduct- } \\
\text { ance, } \\
\text { lab } \\
(\mu \mathrm{S} / \mathrm{cm})\end{array}$ & $\begin{array}{c}\text { Specific } \\
\text { conduct- } \\
\text { ance, } \\
\text { field } \\
\text { ( } \mathrm{HS} / \mathrm{cm})\end{array}$ & $\begin{array}{c}\text { Temper- } \\
\text { ature } \\
\left({ }^{\circ} \mathrm{C}\right)\end{array}$ \\
\hline \multirow[t]{2}{*}{46} & \multirow[t]{2}{*}{ Bear River near Preston, ID } & \multirow[t]{2}{*}{ MS } & 03-14-01 & 1240 & 356 & 11.8 & 109 & 8.2 & - & 1,060 & 5.3 \\
\hline & & & 08-02-01 & 0750 & 1,010 & 6.2 & 77 & 8.1 & 896 & - & 18.2 \\
\hline \multirow[t]{2}{*}{47} & \multirow{2}{*}{$\begin{array}{l}\text { Weston Creek at mouth, near } \\
\text { Weston, ID }\end{array}$} & \multirow[t]{2}{*}{$\mathrm{T}$} & 03-14-01 & 1010 & 8.8 & 12.0 & 107 & 8.1 & - & 1,140 & 3.8 \\
\hline & & & 08-01-01 & 1120 & .45 & 12.5 & 144 & 8.0 & - & 1,230 & 16.6 \\
\hline \multirow[t]{2}{*}{48} & \multirow{2}{*}{$\begin{array}{l}\text { Bear River at Idaho-Utah } \\
\text { Stateline }\end{array}$} & \multirow[t]{2}{*}{ MS } & 03-13-01 & 1430 & 370 & 10.9 & 105 & 8.3 & - & 1,050 & 6.7 \\
\hline & & & $08-02-01$ & 1500 & 903 & 8.4 & 111 & 8.3 & - & 889 & 21.2 \\
\hline \multirow[t]{2}{*}{49} & \multirow{2}{*}{$\begin{array}{l}\text { Worm Creek at } 800 \text { E., near } \\
\text { Franklin, ID }\end{array}$} & \multirow[t]{2}{*}{$\mathrm{T}$} & 03-13-01 & 1630 & 16 & 9.9 & 100 & 8.3 & - & 832 & 7.9 \\
\hline & & & 08-01-01 & 1000 & .36 & 5.7 & 63 & 8.0 & 745 & 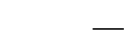 & 16.0 \\
\hline \multirow[t]{2}{*}{50} & \multirow[t]{2}{*}{ Spring Creek near Cove, UT } & \multirow[t]{2}{*}{$\mathrm{T}$} & 03-13-01 & 1200 & 14 & 12.4 & 118 & 8.1 & - & 418 & 6.6 \\
\hline & & & 08-01-01 & 0850 & .12 & 3.1 & 36 & 7.6 & 555 & - & 15.8 \\
\hline \multirow[t]{2}{*}{51} & \multirow[t]{2}{*}{ Cub River near Richmond, UT } & \multirow[t]{2}{*}{$\mathrm{T}$} & 03-13-01 & 0940 & 95 & 11.4 & 101 & 8.2 & - & 568 & 3.9 \\
\hline & & & 08-02-01 & 1040 & 6.7 & 9.2 & 114 & 8.2 & - & 618 & 18.3 \\
\hline \multirow[t]{2}{*}{52} & \multirow[t]{2}{*}{ Bear River near Benson UT } & \multirow[t]{2}{*}{ MS } & 03-13-01 & 1410 & 712 & 10 & 95 & 8.4 & - & 1,020 & 6.1 \\
\hline & & & 08-01-01 & 1620 & 1,030 & 7.2 & 95 & 8.0 & - & 895 & 21.6 \\
\hline 53 & $\begin{array}{l}\text { Blacksmith Fork at } 2900 \text { S., near } \\
\text { Millville, UT }\end{array}$ & $\mathrm{T}$ & $03-12-01$ & 1640 & 72 & 11 & 91 & 8.3 & - & 420 & 7.1 \\
\hline \multirow[t]{2}{*}{54} & \multirow{2}{*}{$\begin{array}{l}\text { Logan River below Blacksmith } \\
\text { Fork, near Logan, UT }\end{array}$} & \multirow[t]{2}{*}{$\mathrm{T}$} & 03-12-01 & 0910 & 204 & 9.8 & 91 & 8.2 & - & 456 & 4.9 \\
\hline & & & 07-31-01 & 1330 & 3.0 & 8.2 & 106 & 7.8 & 586 & - & 20.2 \\
\hline \multirow[t]{2}{*}{55} & Spring Creek at 600 S., near & $\mathrm{T}$ & 03-12-01 & 1140 & 101 & 8.8 & 80 & 8.1 & - & 843 & 4.7 \\
\hline & Logan, UT & & 07-31-01 & 1210 & - & - & - & - & 644 & - & - \\
\hline 56 & Little Bear River at 600 S., near & $\mathrm{T}$ & 03-12-01 & 1440 & 102 & 9.5 & 86 & 8.2 & - & 590 & 4.1 \\
\hline & Mendon, UT & & $07-31-01$ & 0930 & 14 & 6.1 & 76 & 8.0 & - & 705 & 18.8 \\
\hline 57 & Hopkins Slough near Benson, UT & $\mathrm{T}$ & 03-12-01 & 1700 & 20 & 9.3 & 91 & 8.2 & - & 831 & 7.3 \\
\hline & & & 07-31-01 & 1120 & 1.7 & 9.3 & 108 & 7.9 & 619 & - & 16.0 \\
\hline 58 & Logan wastewater-treatment plant & $\mathrm{T}$ & 03-11-01 & 1800 & 62 & 10 & 90 & 8.0 & - & 736 & 4.0 \\
\hline & ditch near Logan, UT & & $07-31-01$ & 0830 & 6.5 & 6.9 & 88 & 7.7 & 902 & - & 20.7 \\
\hline 59 & $\begin{array}{l}\text { Swift Slough at } 1300 \text { E., near } \\
\text { Logan UT }\end{array}$ & $\mathrm{T}$ & $07-31-01$ & 0920 & .7 & 8 & 92 & 7.9 & 583 & - & 16.5 \\
\hline 60 & Little Bear River at 3000 N., at & $\mathrm{T}$ & 03-13-01 & 1040 & 1,070 & 8.1 & 75 & 8.2 & - & 610 & 5.3 \\
\hline & Benson Marina, UT & & 08-01-01 & 1130 & 0 & 6.5 & 90 & 8.4 & - & 850 & 24.0 \\
\hline 61 & $\begin{array}{l}\text { Newton Creek at mouth, near } \\
\text { Newton, UT }\end{array}$ & $\mathrm{T}$ & $07-31-01$ & 1500 & 4.1 & 8.6 & 119 & 8.4 & - & 888 & 23.6 \\
\hline 62 & Bear River near Collinston, UT & MS & 03-11-01 & 1530 & ${ }^{1} 1,380$ & 10.5 & 98 & 8.2 & - & 844 & 5.3 \\
\hline & & & $07-30-01$ & 1430 & 17 & 8.4 & 116 & 8.3 & - & 1,750 & 23.4 \\
\hline 63 & $\begin{array}{l}\text { Bear River at U-30 crossing, near } \\
\text { Deweywille, UT }\end{array}$ & MS & 07-30-01 & 1550 & 25 & 7.9 & 110 & 8.3 & - & 1,500 & 24.4 \\
\hline 64 & $\begin{array}{l}\text { Malad River south of Bear River } \\
\text { City, UT }\end{array}$ & $\mathrm{T}$ & $07-30-01$ & 1410 & 16 & 12.4 & 178 & 8.4 & - & 2,150 & 25.3 \\
\hline 65 & Bear River near Corinne, UT & MS & 03-12-01 & 1100 & 1,690 & - & - & 8.5 & - & 1,200 & 6.5 \\
\hline & & & 07-30-01 & 1150 & 230 & 9.9 & 136 & 8.3 & - & 4,860 & 23.4 \\
\hline
\end{tabular}

'Daily mean discharge.

${ }^{2}$ Bear Lake Outlet Canal considered main-stem site because Bear River is diverted from main channel upstream from confluence of outlet canal with main channel. 
Table 6. Statistical summary of discharge, and concentrations of dissolved solids, suspended sediment, and nutrients for water samples collected from streams in the Bear River basin, March 2001

[ft³/s, cubic feet per second; mg/L, milligrams per liter; <, less than; e, estimated; —, not calculated]

\begin{tabular}{|c|c|c|c|c|c|c|c|c|}
\hline \multirow{2}{*}{ Sites } & \multirow{2}{*}{$\begin{array}{c}\text { Number of } \\
\text { sites }\end{array}$} & \multirow{2}{*}{ Minimum } & \multicolumn{3}{|c|}{ Percentile } & \multirow{2}{*}{ Maximum } & \multirow{2}{*}{ Mean } & \multirow{2}{*}{$\begin{array}{l}\text { Standard } \\
\text { deviation }\end{array}$} \\
\hline & & & 25th & $\begin{array}{c}\text { 50th } \\
\text { (median) }\end{array}$ & 75th & & & \\
\hline \multicolumn{9}{|c|}{ Discharge $\left(\mathrm{ft}^{3} / \mathrm{s}\right)$} \\
\hline All & 57 & 0.7 & 13 & 37 & 153 & 1,690 & 167 & 325 \\
\hline Main stem & 25 & 7 & 78 & 153 & 356 & 1,690 & 298 & 410 \\
\hline Tributary & 32 & .7 & 7.1 & 15 & 43 & 1,070 & 64 & 189 \\
\hline \multicolumn{9}{|c|}{ Dissolved solids (mg/L) } \\
\hline All & 56 & 116 & 281 & 335 & 490 & 1,080 & 401 & 185 \\
\hline Main stem & 24 & 116 & 302 & 349 & 494 & 672 & 401 & 136 \\
\hline Tributary & 32 & 188 & 246 & 329 & 490 & 1,080 & 401 & 217 \\
\hline \multicolumn{9}{|c|}{ Suspended sediment (mg/L) } \\
\hline All & 55 & 2 & 14 & 38 & 62 & 861 & 79 & 158 \\
\hline Main stem & 24 & 2 & 12 & 28 & 49 & 98 & 35 & 30 \\
\hline Tributary & 31 & 5 & 18 & 48 & 80 & 861 & 114 & 205 \\
\hline \multicolumn{9}{|c|}{ Dissolved ammonia (mg/L) } \\
\hline All & 37 & $<.021$ & $.024 \mathrm{e}$ & .149 & .206 & 1.43 & - & - \\
\hline Main stem & 24 & $<.021$ & .050 & .153 & .200 & .473 & - & - \\
\hline Tributary & 13 & $<.021$ & $.022 \mathrm{e}$ & .149 & .510 & 1.43 & - & - \\
\hline \multicolumn{9}{|c|}{ Dissolved nitrite plus nitrate (mg/L) } \\
\hline All & 56 & $.042 \mathrm{e}$ & .135 & .526 & 1.11 & 5.28 & .915 & 1.10 \\
\hline Main stem & 25 & .044 & .122 & .429 & 1.01 & 1.76 & .600 & .543 \\
\hline Tributary & 31 & $.042 \mathrm{e}$ & .165 & .666 & 1.86 & 5.28 & 1.17 & 1.36 \\
\hline \multicolumn{9}{|c|}{ Total nitrogen (mg/L) } \\
\hline All & 33 & .262 & .701 & 1.5 & 1.77 & 8.09 & 1.71 & 1.51 \\
\hline Main stem & 21 & .325 & .701 & 1.41 & 1.65 & 2.82 & 1.29 & .764 \\
\hline Tributary & 12 & .262 & 1.18 & 1.75 & 3.39 & 8.09 & 2.43 & 2.16 \\
\hline \multicolumn{9}{|c|}{ Total phosphorus (mg/L) } \\
\hline All & 57 & $<.02$ & .040 & .073 & .273 & 2.4 & - & - \\
\hline Main stem & 25 & $<.02$ & .036 & .053 & .112 & .49 & - & - \\
\hline Tributary & 32 & $<.02$ & .051 & .182 & .406 & 2.4 & - & - \\
\hline
\end{tabular}


Table 7. Statistical summary of discharge, and concentrations of dissolved solids, suspended sediment, and nutrients for water samples collected from streams in the Bear River basin, July-August 2001

[ft $\mathrm{ft}^{3} / \mathrm{s}$, cubic feet per second; mg/L, milligrams per liter; <, less than; e, estimated; —, not calculated]

\begin{tabular}{|c|c|c|c|c|c|c|c|c|}
\hline \multirow{2}{*}{ Sites } & \multirow{2}{*}{$\begin{array}{l}\text { Number of } \\
\text { sites }\end{array}$} & \multirow[b]{2}{*}{ Minimum } & \multicolumn{3}{|c|}{ Percentile } & \multirow{2}{*}{ Maximum } & \multirow{2}{*}{ Mean } & \multirow{2}{*}{$\begin{array}{l}\text { Standard } \\
\text { deviation }\end{array}$} \\
\hline & & & 25th & $\begin{array}{c}\text { 50th } \\
\text { (median) }\end{array}$ & 75th & & & \\
\hline \multicolumn{9}{|c|}{ Discharge $\left(\mathrm{ft}^{3} / \mathrm{s}\right)$} \\
\hline All & 62 & 0 & 0.8 & 10 & 88 & 1,540 & 243 & 464 \\
\hline Main stem & 27 & .5 & 19.5 & 108 & 1,105 & 1,300 & 493 & 549 \\
\hline Tributary & 35 & 0 & .4 & 1.5 & 5.4 & 1,540 & 49 & 260 \\
\hline \multicolumn{9}{|c|}{ Dissolved solids (mg/L) } \\
\hline All & 60 & 117 & 334 & 418 & 487 & 2,540 & 478 & 349 \\
\hline Main stem & 25 & 117 & 379 & 443 & 485 & 2,540 & 525 & 447 \\
\hline Tributary & 35 & 196 & 317 & 373 & 490 & 1,540 & 443 & 260 \\
\hline \multicolumn{9}{|c|}{ Suspended sediment (mg/L) } \\
\hline All & 61 & 2 & 13 & 38 & 61 & 179 & 45 & 40 \\
\hline Main stem & 27 & 2 & 15 & 38 & 56 & 141 & 41 & 35 \\
\hline Tributary & 34 & 3 & 12 & 36 & 69 & 179 & 48 & 43 \\
\hline \multicolumn{9}{|c|}{ Dissolved ammonia (mg/L) } \\
\hline All & 38 & $<.021$ & $<.021$ & $.024 \mathrm{e}$ & $.029 \mathrm{e}$ & .198 & - & - \\
\hline Main stem & 24 & $<.021$ & $<.021$ & $.023 \mathrm{e}$ & $.026 \mathrm{e}$ & .198 & - & - \\
\hline Tributary & 14 & $<.021$ & $<.021$ & $.025 \mathrm{e}$ & $.030 \mathrm{e}$ & .061 & - & - \\
\hline \multicolumn{9}{|c|}{ Dissolved nitrite plus nitrate (mg/L) } \\
\hline All & 61 & $<.023$ & $.025 \mathrm{e}$ & .041 & .22 & 3.06 & - & - \\
\hline Main stem & 25 & $.023 \mathrm{e}$ & $.026 \mathrm{e}$ & .05 & .1 & .69 & .09 & .14 \\
\hline Tributary & 36 & $<.023$ & $<.023$ & .032 & .578 & 3.06 & - & - \\
\hline \multicolumn{9}{|c|}{ Total nitrogen (mg/L) } \\
\hline All & 38 & .107 & .402 & .543 & .675 & 1.85 & .604 & .379 \\
\hline Main stem & 24 & .211 & .475 & .543 & .616 & 1.08 & .543 & .189 \\
\hline Tributary & 14 & .107 & .241 & .537 & 1.12 & 1.85 & .710 & .572 \\
\hline \multicolumn{9}{|c|}{ Total phosphorus (mg/L) } \\
\hline All & 60 & $<.02$ & .030 & .067 & .111 & 2.30 & - & - \\
\hline Main stem & 25 & $<.02$ & .040 & .054 & .087 & .287 & - & - \\
\hline Tributary & 35 & $<.02$ & .026 & .082 & .173 & 2.30 & - & - \\
\hline
\end{tabular}


Table 8. Yield of nutrients, dissolved solids, and suspended sediment from Bear River tributary basins, March and JulyAugust 2001

[Site designation: UT, Utah; WY, Wyoming; ID, Idaho; lbs/acre/day, pounds per acre per day;一, not calculated; <, less than]

\begin{tabular}{|c|c|c|c|c|c|c|}
\hline \multirow{3}{*}{$\begin{array}{c}\text { Site } \\
\text { number } \\
\text { (fig. 1) }\end{array}$} & \multirow{3}{*}{ Site designation } & \multirow{3}{*}{$\begin{array}{c}\text { Subbasin } \\
\text { area } \\
\text { (acres) }\end{array}$} & \multicolumn{4}{|c|}{ March } \\
\hline & & & \multicolumn{4}{|c|}{ Ibs/acre/day x $10^{4}$} \\
\hline & & & $\begin{array}{l}\text { Dissolved } \\
\text { ammonia }\end{array}$ & $\begin{array}{c}\text { Nitrite } \\
\text { plus } \\
\text { nitrate }\end{array}$ & $\begin{array}{l}\text { Total nitro- } \\
\text { gen }\end{array}$ & $\begin{array}{l}\text { Total } \\
\text { phos- } \\
\text { phorus }\end{array}$ \\
\hline 2 & Sulphur Creek at mouth, near Evanston, WY & 49,856 & - & 1.3 & - & 3.2 \\
\hline 7 & Saleratus Creek near Woodruff, UT & 138,240 & - & .4 & - & .4 \\
\hline 8 & Genes (Woodruff) Creek at Woodruff, UT & 78,080 & - & - & - & .2 \\
\hline 9 & Big Creek at Highway 89, near Randolph, UT & 45,760 & - & .9 & - & 1.1 \\
\hline 11 & Otter Creek near Randolph, UT & 24,384 & - & 4.6 & - & 8.2 \\
\hline 13 & Twin Creek at Highway 89, near Leefe, WY & 163,840 & - & .2 & - & .2 \\
\hline 14 & Sublette Creek at Highway 30, near Cokeville, WY & 19,712 & - & - & - & - \\
\hline 16 & Spring Creek at Cokeville, WY & 178,560 & $<.1$ & .8 & 1.8 & .1 \\
\hline 17 & Smiths Fork at Highway 30, near Cokeville, WY & 175,360 & .4 & .8 & 5.1 & .5 \\
\hline 20 & Thomas Fork at mouth, near Border, WY & 149,760 & .2 & 7.4 & 8.8 & .3 \\
\hline 25 & Ovid Creek near Ovid, ID & 69,120 & - & .1 & - & $<.1$ \\
\hline 27 & Georgetown Creek at Georgetown, ID & 22,464 & - & 4.8 & - & 2.3 \\
\hline 28 & Stauffer Creek near Georgetown, ID & 22,592 & - & 2.8 & - & 1.1 \\
\hline 29 & Eightmile Creek at Eightmile Road, near Soda Springs, ID & 22,528 & - & 1.1 & - & .5 \\
\hline 30 & Bailey Creek near Soda Springs, ID & 4,352 & - & 6.6 & - & 2.3 \\
\hline 32 & Soda Creek at mouth, at Soda Springs, ID & 32,192 & 4.2 & 30 & - & 3.6 \\
\hline 35 & Densmore Creek at Mouth, near Thatcher, ID & 11,072 & - & - & - & - \\
\hline 37 & Whiskey Creek at Highway 34, near Thatcher, ID & 2,944 & - & 570 & - & 38 \\
\hline 38 & Trout Creek at Thatcher, ID & 31,168 & 3.0 & 30 & 48 & 3.6 \\
\hline 41 & Mink Creek at mouth, near Preston, ID & 40,512 & .2 & 11 & 16 & .7 \\
\hline 43 & Battle Creek near Preston, ID & 40,512 & 1.4 & 16 & 29 & 9.0 \\
\hline 44 & Deep Creek at mouth, near Preston, ID & 86,400 & 3.5 & 6.3 & 23 & 4.6 \\
\hline 45 & Fivemile Creek near Preston, ID & 10,432 & - & 53 & - & 4.2 \\
\hline 47 & Weston Creek at mouth, near Weston, ID & 46,912 & - & 25 & - & 6.2 \\
\hline 49 & Worm Creek at 800 E., near Franklin, ID & 29,504 & - & 130 & - & 17 \\
\hline 50 & Spring Creek near Cove, UT & 11,648 & - & 110 & - & 14 \\
\hline 51 & Cub River near Richmond, UT & 128,000 & 27 & 82 & 160 & 16 \\
\hline 53 & Blacksmith Fork at 2900 S., near Millville, UT & 180,480 & - & 3.6 & - & .2 \\
\hline 54 & Logan River below Blacksmith Fork, near Logan, UT & 338,560 & .7 & 11 & 17 & .8 \\
\hline 55 & Spring Creek at 600 S., near Logan, UT & 15,680 & 500 & 1,800 & 2,800 & 441 \\
\hline 56 & Little Bear at 600 S., near Mendon, UT & 167,680 & 8.1 & 22 & 54 & 5.7 \\
\hline 57 & Hopkins Slough near Benson, UT & 13,120 & 7.7 & 220 & - & 19 \\
\hline 58 & Logan wastewater-treatment plant ditch near Logan, UT & 1,600 & 160 & 1,100 & - & 5,000 \\
\hline 59 & Swift Slough at 1300 E., near Logan UT & 22,912 & - & - & - & - \\
\hline 60 & Little Bear River at 3000 N., at Benson Marina, UT & 583,040 & 54 & 100 & 250 & 45 \\
\hline 61 & Newton Creek at mouth, near Newton, UT & 38,592 & - & - & - & - \\
\hline 64 & Malad River south of Bear River City, UT & 453,760 & - & - & - & - \\
\hline
\end{tabular}


Table 8. Yield of nutrients, dissolved solids, and suspended sediment from Bear River tributary basins, March and JulyAugust 2001-Continued

\begin{tabular}{|c|c|c|c|c|c|c|c|c|}
\hline \multirow{3}{*}{$\begin{array}{c}\text { Site } \\
\text { number } \\
\text { (fig. 1) }\end{array}$} & \multirow{2}{*}{\multicolumn{2}{|c|}{$\begin{array}{c}\text { March } \\
\text { Ibs/acre/day x } 10^{2}\end{array}$}} & \multicolumn{6}{|c|}{ July-August } \\
\hline & & & \multicolumn{4}{|c|}{ Ibs/acre/day x $10^{4}$} & \multicolumn{2}{|c|}{ Ibs/acre/day x $10^{2}$} \\
\hline & $\begin{array}{l}\text { Dissolved } \\
\text { solids }\end{array}$ & $\begin{array}{c}\text { Suspended } \\
\text { sediment }\end{array}$ & $\begin{array}{c}\text { Dissolved } \\
\text { ammonia }\end{array}$ & $\begin{array}{l}\text { Nitrite plus } \\
\text { nitrate }\end{array}$ & $\begin{array}{c}\text { Total } \\
\text { nitrogen }\end{array}$ & $\begin{array}{c}\text { Total } \\
\text { phos- } \\
\text { phorus }\end{array}$ & $\begin{array}{l}\text { Dissolved } \\
\text { solids }\end{array}$ & $\begin{array}{l}\text { Suspended } \\
\text { sediment }\end{array}$ \\
\hline 2 & 25 & 6 & - & 0.3 & - & 0.8 & 100 & 2.4 \\
\hline 7 & 9 & $<1$ & - & - & - & - & - & - \\
\hline 8 & 1 & - & - & $<.1$ & - & $<.1$ & .5 & $<.1$ \\
\hline 9 & 47 & 3 & - & $<.1$ & - & $<.1$ & .6 & $<.1$ \\
\hline 11 & 100 & 130 & - & $<.1$ & - & $<.1$ & 1.8 & .1 \\
\hline 13 & 14 & 2 & - & $<.1$ & - & $<.1$ & 7.1 & .2 \\
\hline 14 & - & - & - & $<.1$ & - & $<.1$ & .4 & $<.1$ \\
\hline 16 & 13 & 1 & .2 & .1 & 1.2 & $<.1$ & 12 & .6 \\
\hline 17 & 50 & 3 & .6 & .4 & 3.2 & .3 & 37 & 1.6 \\
\hline 20 & 31 & 4 & $<.1$ & $<.1$ & .2 & $<.1$ & 1.5 & .2 \\
\hline 25 & 2 & $<1$ & - & $<.1$ & - & $<.1$ & 2.4 & $<.1$ \\
\hline 27 & 120 & 7 & - & $<.1$ & - & $<.1$ & 4.9 & .1 \\
\hline 28 & 30 & 2 & - & $<.1$ & - & $<.1$ & 3.8 & - \\
\hline 29 & 34 & 6 & - & $<.1$ & - & $<.1$ & .8 & $<.1$ \\
\hline 30 & 120 & 28 & - & 1.4 & - & .7 & 20 & 6.4 \\
\hline 32 & 260 & 17 & $<.1$ & .1 & .3 & $<.1$ & 25 & 2.9 \\
\hline 35 & - & - & - & $<.1$ & - & - & .2 & $<.1$ \\
\hline 37 & 910 & 180 & - & 500 & - & 11 & 770 & 110 \\
\hline 38 & 93 & 12 & .3 & .2 & .8 & .7 & 26 & 4.6 \\
\hline 41 & 21 & $<1$ & .1 & .1 & 1.2 & .2 & 8.2 & 1.5 \\
\hline 43 & 88 & 70 & $<.1$ & .2 & 1.0 & .2 & 11 & .9 \\
\hline 44 & 36 & 27 & $<.1$ & 1.5 & 2.1 & .2 & 7.0 & .4 \\
\hline 45 & 99 & 24 & - & 7.1 & - & 1.8 & 44 & 7.3 \\
\hline 47 & 73 & 77 & - & .8 & - & $<.1$ & 4.0 & .2 \\
\hline 49 & 130 & 36 & - & $<.1$ & - & .3 & 2.7 & - \\
\hline 50 & 160 & 38 & - & .2 & - & .1 & 1.8 & $<.1$ \\
\hline 51 & 130 & 25 & .1 & 2.8 & 5.2 & .4 & 10 & 1.2 \\
\hline 53 & 53 & 2.8 & - & - & - & - & - & - \\
\hline 54 & 80 & 2.6 & $<.1$ & .1 & .3 & $<.1$ & 1.6 & .3 \\
\hline 55 & 1,700 & 100 & - & - & - & - & - & - \\
\hline 56 & 110 & 8.2 & .2 & 2.6 & 5.9 & .9 & 19 & 3.7 \\
\hline 57 & 350 & 37 & - & 12 & - & 1.9 & 24 & 7.1 \\
\hline 58 & 7,800 & 1,150 & - & 210 & - & 500 & 1,100 & 200 \\
\hline 59 & - & - & - & $<.1$ & - & .1 & 5.9 & .5 \\
\hline 60 & 513 & 48 & - & - & - & - & - & - \\
\hline 61 & - & - & - & 2.9 & - & .6 & 30 & 2.3 \\
\hline 64 & - & - & - & 2.5 & - & .8 & 22 & 2.8 \\
\hline
\end{tabular}


Table 9. Results of chemical analyses for water samples collected from selected sites on the Bear River and its tributaries, March and July-August 2001

[Site designation:UT, Utah; ID, Idaho; WY, Wyoming; Site type: MS, main stem; T, tributary; mg/L, milligrams per liter; ${ }^{\circ} \mathrm{C}$, degrees Celsius; $\mu \mathrm{g} / \mathrm{L}$, micrograms per liter; u, analyzed by Utah Health Laboratory;-, no data; <, less than; e, estimated]

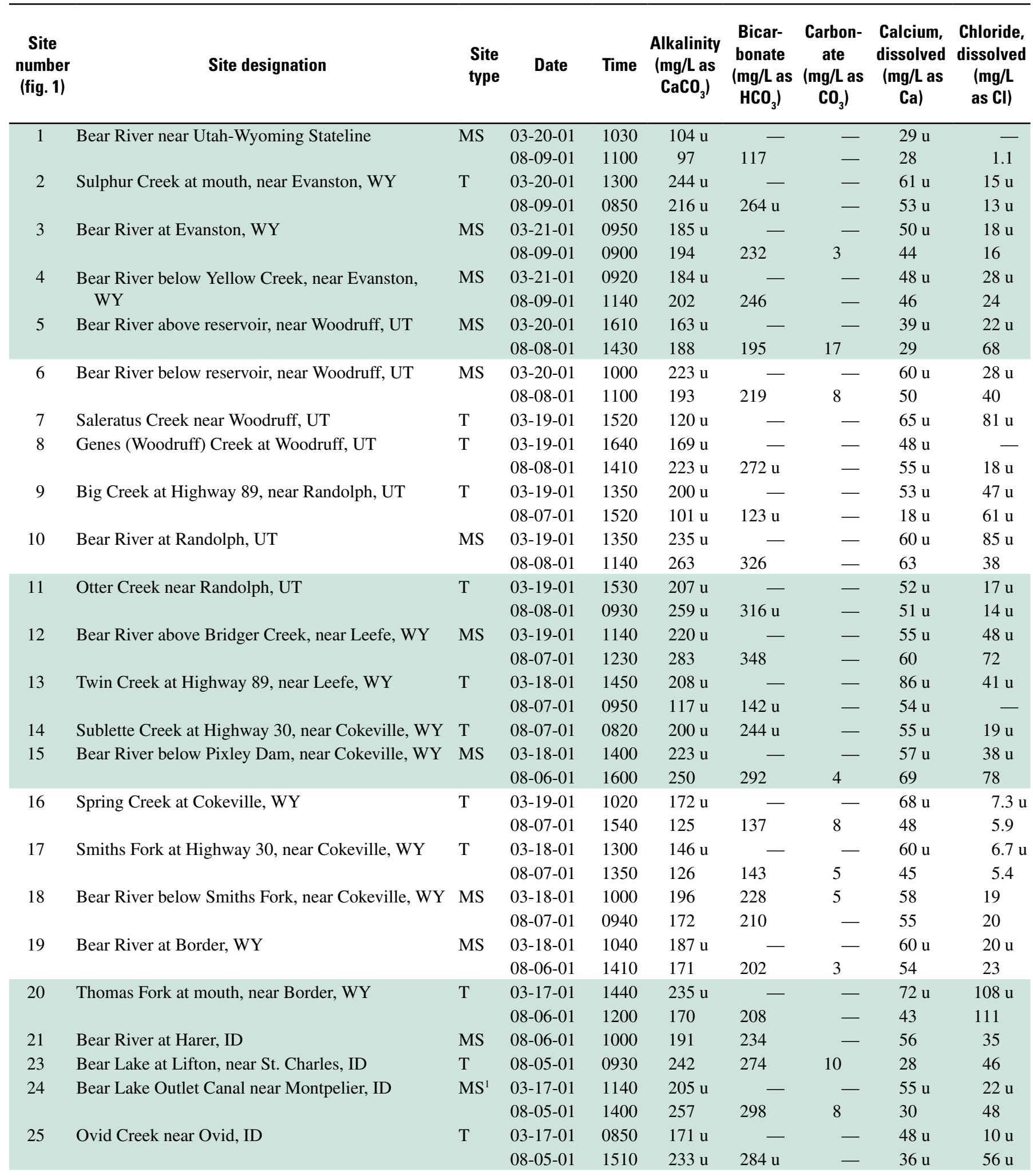


Table 9. Results of chemical analyses for water samples collected from selected sites on the Bear River and its tributaries, March and July-August 2001-Continued

\begin{tabular}{|c|c|c|c|c|c|c|c|c|c|c|}
\hline $\begin{array}{c}\text { Site } \\
\text { number } \\
\text { (fig. 1) }\end{array}$ & $\begin{array}{c}\text { Fluoride, } \\
\text { dissolved } \\
\text { (mg/L } \\
\text { as F) }\end{array}$ & $\begin{array}{c}\text { Silica, } \\
\text { dissolved } \\
\text { (mg/L as } \\
\mathrm{SiO}_{2} \text { ) }\end{array}$ & $\begin{array}{c}\text { Solids, } \\
\text { residue at } \\
180^{\circ} \mathrm{C}, \\
\text { dissolved } \\
\text { (mg/L) }\end{array}$ & $\begin{array}{c}\text { Hardness, } \\
\text { total } \\
\text { (mg/L as } \\
\mathrm{CaCO}_{3} \text { ) }\end{array}$ & $\begin{array}{c}\text { Magnesium, } \\
\text { dissolved } \\
(\mathrm{mg} / \mathrm{L} \\
\text { as } \mathrm{Mg})\end{array}$ & $\begin{array}{c}\text { Manganese, } \\
\text { dissolved } \\
(\mu \mathrm{g} / \mathrm{L} \\
\text { as } \mathrm{Mn})\end{array}$ & $\begin{array}{c}\text { Potassium, } \\
\text { dissolved } \\
\text { (mg/L } \\
\text { as K) }\end{array}$ & $\begin{array}{c}\text { Sodium, } \\
\text { dissolved } \\
\text { (mg/L as } \\
\mathrm{Na} \text { ) }\end{array}$ & $\begin{array}{c}\text { Sulfate, } \\
\text { dissolved } \\
\text { (mg/L as } \\
\left.\mathrm{SO}_{4}\right)\end{array}$ & $\begin{array}{c}\text { Iron, } \\
\text { dissolved } \\
(\mu \mathrm{g} / \mathrm{L} \\
\text { as } \mathrm{Fe})\end{array}$ \\
\hline \multirow[t]{2}{*}{1} & - & - & $116 \mathrm{u}$ & - & $8.7 \mathrm{u}$ & - & - & $2.2 \mathrm{u}$ & - & - \\
\hline & $<.2$ & 3.5 & 117 & 101 & 7.7 & 3.3 & .5 & 1.8 & 3.3 & $<30$ \\
\hline \multirow[t]{2}{*}{2} & - & - & $346 \mathrm{u}$ & - & $23 \mathrm{u}$ & $308 \mathrm{u}$ & $11 \mathrm{u}$ & $18 \mathrm{u}$ & $31 \mathrm{u}$ & - \\
\hline & - & - & $334 \mathrm{u}$ & - & $29 u$ & - & $3 u$ & $15 \mathrm{u}$ & $38 \mathrm{u}$ & - \\
\hline \multirow[t]{2}{*}{3} & - & - & $302 \mathrm{u}$ & - & $22 \mathrm{u}$ & $53 \mathrm{u}$ & $3.5 \mathrm{u}$ & $16 \mathrm{u}$ & $39 \mathrm{u}$ & - \\
\hline & .2 & 5.5 & 281 & 208 & 24 & 27 & 2.5 & 15 & 30 & $30 \mathrm{e}$ \\
\hline \multirow[t]{2}{*}{4} & - & - & $300 \mathrm{u}$ & - & $24 \mathrm{u}$ & $72 \mathrm{u}$ & $5.1 \mathrm{u}$ & $21 \mathrm{u}$ & $34 \mathrm{u}$ & - \\
\hline & .2 & 4.7 & 287 & 220 & 26 & 29 & 2.7 & 19 & 28 & $40 \mathrm{e}$ \\
\hline \multirow[t]{2}{*}{5} & - & - & $258 \mathrm{u}$ & - & $20 \mathrm{u}$ & $97 \mathrm{u}$ & $6.6 \mathrm{u}$ & $18 \mathrm{u}$ & $22 \mathrm{u}$ & - \\
\hline & .3 & 8.4 & 379 & 218 & 35 & 18 & 5.8 & 45 & 46 & $20 \mathrm{e}$ \\
\hline \multirow[t]{2}{*}{6} & - & - & $300 \mathrm{u}$ & - & $23 \mathrm{u}$ & $97 \mathrm{u}$ & $2.3 \mathrm{u}$ & $24 \mathrm{u}$ & $24 \mathrm{u}$ & - \\
\hline & $.2 \mathrm{e}$ & 11 & 336 & 216 & 22 & 332 & 3.1 & 29 & 32 & 10 \\
\hline 7 & - & - & $760 \mathrm{u}$ & - & $61 \mathrm{u}$ & $87 \mathrm{u}$ & $17 \mathrm{u}$ & $74 \mathrm{u}$ & $346 \mathrm{u}$ & - \\
\hline \multirow[t]{2}{*}{8} & - & - & $228 \mathrm{u}$ & - & $15 \mathrm{u}$ & $19 \mathrm{u}$ & $5.4 \mathrm{u}$ & $12 \mathrm{u}$ & $24 \mathrm{u}$ & - \\
\hline & - & - & $310 \mathrm{u}$ & - & $24 \mathrm{u}$ & - & $1.8 \mathrm{u}$ & $16 \mathrm{u}$ & $21 \mathrm{u}$ & - \\
\hline \multirow[t]{2}{*}{9} & - & - & $304 \mathrm{u}$ & - & $22 \mathrm{u}$ & $11 \mathrm{u}$ & $2.7 \mathrm{u}$ & $32 \mathrm{u}$ & $23 \mathrm{u}$ & - \\
\hline & - & - & $256 \mathrm{u}$ & - & $23 \mathrm{u}$ & - & $3 \mathrm{u}$ & $41 \mathrm{u}$ & $36 \mathrm{u}$ & - \\
\hline \multirow[t]{2}{*}{10} & - & - & $406 \mathrm{u}$ & - & $27 \mathrm{u}$ & $158 \mathrm{u}$ & $2.6 \mathrm{u}$ & $57 \mathrm{u}$ & $38 \mathrm{u}$ & - \\
\hline & $.1 \mathrm{e}$ & 13 & 382 & 282 & 31 & 119 & 2.3 & 30 & 34 & $50 \mathrm{e}$ \\
\hline \multirow[t]{2}{*}{11} & - & - & $246 \mathrm{u}$ & - & $21 \mathrm{u}$ & $16 \mathrm{u}$ & $4.7 \mathrm{u}$ & $11 \mathrm{u}$ & - & - \\
\hline & - & - & $354 \mathrm{u}$ & - & $37 \mathrm{u}$ & - & $2.4 \mathrm{u}$ & $11 \mathrm{u}$ & - & - \\
\hline \multirow[t]{2}{*}{12} & - & - & $328 \mathrm{u}$ & - & $25 \mathrm{u}$ & $105 \mathrm{u}$ & $3.6 \mathrm{u}$ & $34 \mathrm{u}$ & $30 \mathrm{u}$ & - \\
\hline & .2 & 10 & 492 & 323 & 42 & 60 & 3.2 & 53 & 57 & - \\
\hline \multirow[t]{2}{*}{13} & - & - & $600 \mathrm{u}$ & - & $42 \mathrm{u}$ & $20 \mathrm{u}$ & $3.5 \mathrm{u}$ & $64 \mathrm{u}$ & $195 \mathrm{u}$ & - \\
\hline & - & - & $512 \mathrm{u}$ & - & $41 \mathrm{u}$ & - & $4 \mathrm{u}$ & $54 \mathrm{u}$ & $261 \mathrm{u}$ & - \\
\hline 14 & - & - & $368 \mathrm{u}$ & - & $30 \mathrm{u}$ & - & $2.5 \mathrm{u}$ & $23 \mathrm{u}$ & $76 \mathrm{u}$ & - \\
\hline \multirow[t]{2}{*}{15} & - & - & $334 \mathrm{u}$ & - & $29 \mathrm{u}$ & $67 \mathrm{u}$ & $2.9 \mathrm{u}$ & $31 \mathrm{u}$ & $36 \mathrm{u}$ & - \\
\hline & .3 & 15 & 616 & 381 & 50 & 28 & 4.4 & 71 & 116 & $10 \mathrm{e}$ \\
\hline \multirow[t]{2}{*}{16} & - & - & $298 \mathrm{u}$ & - & $20 \mathrm{u}$ & $24 \mathrm{u}$ & $1.3 \mathrm{u}$ & $9.4 \mathrm{u}$ & $83 \mathrm{u}$ & - \\
\hline & $.2 \mathrm{e}$ & 5.9 & 214 & 179 & 15 & 9.1 & .7 & 6.5 & 61 & - \\
\hline \multirow[t]{2}{*}{17} & - & - & $256 \mathrm{u}$ & - & $16 \mathrm{u}$ & $25 \mathrm{u}$ & - & $8.6 \mathrm{u}$ & $64 \mathrm{u}$ & - \\
\hline & $.1 \mathrm{e}$ & 4.6 & 214 & 167 & 13 & 12 & .7 & 5.7 & 55 & - \\
\hline \multirow[t]{2}{*}{18} & .2 & 7.0 & 322 & 227 & 20 & 30 & 1.6 & 17 & 60 & $<10$ \\
\hline & $.2 \mathrm{e}$ & 7.1 & 320 & 225 & 21 & 29 & 1.4 & 19 & 69 & $10 \mathrm{e}$ \\
\hline \multirow[t]{2}{*}{19} & - & - & $304 \mathrm{u}$ & - & $23 \mathrm{u}$ & $24 \mathrm{u}$ & $1.8 \mathrm{u}$ & $19 \mathrm{u}$ & $59 \mathrm{u}$ & - \\
\hline & .2 & 7.6 & 333 & 226 & 22 & 21 & 1.8 & 21 & 73 & $10 \mathrm{e}$ \\
\hline \multirow[t]{2}{*}{20} & - & - & $488 \mathrm{u}$ & - & $26 \mathrm{u}$ & $27 \mathrm{u}$ & $1.4 \mathrm{u}$ & $76 \mathrm{u}$ & $54 \mathrm{u}$ & - \\
\hline & $.1 \mathrm{e}$ & 7.1 & 443 & 217 & 26 & 36 & 1.5 & 72 & 59 & $10 \mathrm{e}$ \\
\hline 21 & .2 & 8.9 & 387 & 251 & 27 & 5.6 & 1.8 & 33 & 85 & $<10$ \\
\hline 23 & .2 & 11 & 417 & 281 & 51 & $<3.0$ & 4.9 & 39 & 70 & $<10$ \\
\hline \multirow[t]{2}{*}{24} & - & - & $288 \mathrm{u}$ & - & $26 \mathrm{u}$ & $21 \mathrm{u}$ & $2.1 \mathrm{u}$ & $19 \mathrm{u}$ & $32 \mathrm{u}$ & - \\
\hline & .2 & 11 & 434 & 285 & 51 & 3.0 & 4.7 & 41 & 73 & $<10$ \\
\hline \multirow[t]{2}{*}{25} & - & - & $204 \mathrm{u}$ & - & $13 \mathrm{u}$ & $8.1 \mathrm{u}$ & $2.8 \mathrm{u}$ & $8.1 \mathrm{u}$ & - & - \\
\hline & - & - & $420 u$ & - & $47 \mathrm{u}$ & - & $6.3 \mathrm{u}$ & $60 \mathrm{u}$ & $57 \mathrm{u}$ & - \\
\hline
\end{tabular}


Table 9. Results of chemical analyses for water samples collected from selected sites on the Bear River and its tributaries, March and July-August 2001-Continued

\begin{tabular}{|c|c|c|c|c|c|c|c|c|c|}
\hline $\begin{array}{c}\text { Site } \\
\text { number } \\
\text { (fig. 1) }\end{array}$ & Site designation & $\begin{array}{l}\text { Site } \\
\text { type }\end{array}$ & Date & Time & $\begin{array}{c}\text { Alkalinity } \\
\text { (mg/L as } \\
\mathrm{CaCO}_{3} \text { ) }\end{array}$ & $\begin{array}{c}\text { Bicar- } \\
\text { bonate } \\
\text { (mg/L as } \\
\mathrm{HCO}_{3} \text { ) }\end{array}$ & $\begin{array}{c}\text { Carbon- } \\
\text { ate } \\
\text { (mg/L as } \\
\mathrm{CO}_{3} \text { ) }\end{array}$ & $\begin{array}{c}\text { Calcium, } \\
\text { dissolved } \\
\text { (mg/L as } \\
\text { Ca) }\end{array}$ & $\begin{array}{c}\text { Chloride, } \\
\text { dissolved } \\
\text { (mg/L } \\
\text { as Cl) }\end{array}$ \\
\hline \multirow[t]{2}{*}{26} & Bear River at Pescadero, ID & MS & $03-17-01$ & 0930 & $221 \mathrm{u}$ & - & - & $64 \mathrm{u}$ & $24 \mathrm{u}$ \\
\hline & & & 08-05-01 & 0930 & 249 & 345 & 6 & 31 & 48 \\
\hline 27 & Georgetown Creek at Georgetown, ID & $\mathrm{T}$ & $03-16-01$ & 1530 & $175 \mathrm{u}$ & - & - & $59 \mathrm{u}$ & - \\
\hline \multirow[t]{2}{*}{28} & Stauffer Creek near Georgetown, ID & $\mathrm{T}$ & 03-16-01 & 1410 & $152 \mathrm{u}$ & - & - & $40 \mathrm{u}$ & $8.5 \mathrm{u}$ \\
\hline & & & 08-05-01 & 1350 & $171 \mathrm{u}$ & $208 \mathrm{u}$ & - & $44 \mathrm{u}$ & $4.6 \mathrm{u}$ \\
\hline \multirow[t]{2}{*}{29} & Eightmile Creek at Eightmile Road, near Soda & $\mathrm{T}$ & $03-16-01$ & 1250 & $172 \mathrm{u}$ & - & - & $53 \mathrm{u}$ & $5.5 \mathrm{u}$ \\
\hline & Springs, ID & & 08-04-01 & 1410 & $215 \mathrm{u}$ & $262 \mathrm{u}$ & - & $71 \mathrm{u}$ & $6.6 \mathrm{u}$ \\
\hline 30 & Bailey Creek near Soda Springs, ID & $\mathrm{T}$ & $03-16-01$ & 1340 & $207 \mathrm{u}$ & - & - & $56 \mathrm{u}$ & $4.5 \mathrm{u}$ \\
\hline 32 & & & 08-04-01 & 1040 & 932 & 1,140 & - & 289 & 24 \\
\hline \multirow[t]{2}{*}{33} & Bear River above Soda Point Reservoir, at Soda & MS & $03-16-01$ & 0940 & $235 \mathrm{u}$ & - & - & $69 \mathrm{u}$ & $20 \mathrm{u}$ \\
\hline & Springs, ID & & 08-04-01 & 1220 & 262 & 292 & 14 & 34 & 49 \\
\hline \multirow[t]{2}{*}{34} & Bear River at Alexander, ID & MS & $03-16-01$ & 0930 & $338 \mathrm{u}$ & - & - & $85 \mathrm{u}$ & $27 \mathrm{u}$ \\
\hline & & & 08-04-01 & 1000 & 268 & 318 & 4 & 36 & 50 \\
\hline 35 & Densmore Creek at mouth, near Thatcher, ID & $\mathrm{T}$ & 08-04-01 & 0910 & $339 \mathrm{u}$ & $414 \mathrm{u}$ & - & $47 \mathrm{u}$ & $48 \mathrm{u}$ \\
\hline \multirow[t]{2}{*}{36} & Bear River at Black Canyon, near Turner, ID & MS & $03-15-01$ & 1520 & $280 \mathrm{u}$ & - & - & $54 \mathrm{u}$ & $42 \mathrm{u}$ \\
\hline & & & 08-03-01 & 1500 & 264 & 318 & 2 & 42 & 49 \\
\hline \multirow[t]{2}{*}{37} & Whiskey Creek at Highway 34, near Thatcher, ID & $\mathrm{T}$ & $03-15-01$ & 1300 & $287 \mathrm{u}$ & - & - & $68 \mathrm{u}$ & $39 \mathrm{u}$ \\
\hline & & & 08-03-01 & 1300 & $279 \mathrm{u}$ & $340 \mathrm{u}$ & - & $73 \mathrm{u}$ & $46 \mathrm{u}$ \\
\hline 41 & & & $08-02-01$ & 1330 & 241 & 294 & - & 59 & 13 \\
\hline \multirow[t]{2}{*}{42} & Bear River at Highway 30, near Riverdale, ID & MS & 03-14-01 & 1340 & $318 \mathrm{u}$ & - & - & $80 \mathrm{u}$ & $42 \mathrm{u}$ \\
\hline & & & 08-03-01 & 1010 & 286 & 349 & - & 43 & 52 \\
\hline \multirow[t]{2}{*}{43} & Battle Creek near Preston, ID & $\mathrm{T}$ & 03-14-01 & 1020 & $320 \mathrm{u}$ & - & - & $78 \mathrm{u}$ & $267 \mathrm{u}$ \\
\hline & & & $08-02-01$ & 1140 & 300 & 366 & - & 49 & 78 \\
\hline \multirow[t]{2}{*}{44} & Deep Creek at mouth, near Preston, ID & $\mathrm{T}$ & 03-14-01 & 1530 & $266 \mathrm{u}$ & - & - & $63 \mathrm{u}$ & $95 \mathrm{u}$ \\
\hline & & & 08-01-01 & 1500 & 303 & 370 & - & 46 & 75 \\
\hline \multirow[t]{2}{*}{45} & Fivemile Creek near Preston, ID & $\mathrm{T}$ & 03-14-01 & 1400 & $344 \mathrm{u}$ & - & - & $83 \mathrm{u}$ & $47 \mathrm{u}$ \\
\hline & & & 08-01-01 & 1300 & $349 \mathrm{u}$ & $426 \mathrm{u}$ & - & $88 \mathrm{u}$ & $53 \mathrm{u}$ \\
\hline \multirow[t]{2}{*}{46} & Bear River near Preston, ID & MS & 03-14-01 & 1240 & $335 \mathrm{u}$ & - & - & $79 \mathrm{u}$ & 116 \\
\hline & & & $08-02-01$ & 0750 & 286 & 349 & - & 46 & 76 \\
\hline 47 & Weston Creek at mouth, near Weston, ID & $\mathrm{T}$ & 03-14-01 & 1010 & $284 \mathrm{u}$ & - & - & $92 \mathrm{u}$ & $121 \mathrm{u}$ \\
\hline & & & 08-01-01 & 1120 & $331 \mathrm{u}$ & $404 \mathrm{u}$ & - & $72 \mathrm{u}$ & $133 \mathrm{u}$ \\
\hline 48 & Bear River at Idaho-Utah Stateline & MS & 03-13-01 & 1430 & $333 \mathrm{u}$ & - & - & $78 \mathrm{u}$ & $114 \mathrm{u}$ \\
\hline & & & $08-02-01$ & 1500 & 290 & 353 & - & 56 & 64 \\
\hline 49 & Worm Creek at 800 E., near Franklin, ID & $\mathrm{T}$ & 03-13-01 & 1630 & $315 \mathrm{u}$ & - & - & $60 \mathrm{u}$ & $31 \mathrm{u}$ \\
\hline & & & 08-01-01 & 1000 & $328 \mathrm{u}$ & $400 \mathrm{u}$ & - & $56 \mathrm{u}$ & $34 \mathrm{u}$ \\
\hline
\end{tabular}


Table 9. Results of chemical analyses for water samples collected from selected sites on the Bear River and its tributaries, March and July-August 2001-Continued

\begin{tabular}{|c|c|c|c|c|c|c|c|c|c|c|}
\hline $\begin{array}{c}\text { Site } \\
\text { number } \\
\text { (fig. 1) }\end{array}$ & $\begin{array}{c}\text { Fluoride, } \\
\text { dissolved } \\
\text { (mg/L } \\
\text { as F) }\end{array}$ & $\begin{array}{c}\text { Silica, } \\
\text { dissolved } \\
\text { (mg/L as } \\
\left.\mathrm{SiO}_{2}\right)\end{array}$ & $\begin{array}{c}\text { Solids, } \\
\text { residue at } \\
180{ }^{\circ} \mathrm{C}, \\
\text { dissolved } \\
\text { (mg/L) }\end{array}$ & $\begin{array}{c}\text { Hardness, } \\
\text { total } \\
\text { (mg/L as } \\
\text { CaCO }_{3} \text { ) }\end{array}$ & $\begin{array}{c}\text { Magnesium, } \\
\text { dissolved } \\
(\mathrm{mg} / \mathrm{L} \\
\text { as } \mathrm{Mg})\end{array}$ & $\begin{array}{c}\text { Manganese, } \\
\text { dissolved } \\
(\mu \mathrm{g} / \mathrm{L} \\
\text { as } \mathrm{Mn})\end{array}$ & $\begin{array}{c}\text { Potassium, } \\
\text { dissolved } \\
\text { (mg/L } \\
\text { as K) }\end{array}$ & $\begin{array}{c}\text { Sodium, } \\
\text { dissolved } \\
\text { (mg/L as } \\
\mathrm{Na})\end{array}$ & $\begin{array}{c}\text { Sulfate, } \\
\text { dissolved } \\
\text { (mg/L as } \\
\left.\mathrm{SO}_{4}\right)\end{array}$ & $\begin{array}{c}\text { Iron, } \\
\text { dissolved } \\
(\mu \mathrm{g} / \mathrm{L} \\
\text { as } \mathrm{Fe})\end{array}$ \\
\hline \multirow[t]{2}{*}{26} & - & - & $346 \mathrm{u}$ & - & $27 \mathrm{u}$ & $20 \mathrm{u}$ & $2.2 \mathrm{u}$ & $23 \mathrm{u}$ & $59 \mathrm{u}$ & - \\
\hline & .2 & 11 & 436 & 290 & 52 & $<3.0$ & 4.6 & 41 & 73 & $<10$ \\
\hline \multirow[t]{2}{*}{27} & - & - & $230 \mathrm{u}$ & - & $17 \mathrm{u}$ & - & - & $2.4 \mathrm{u}$ & $36 \mathrm{u}$ & - \\
\hline & - & - & $252 \mathrm{u}$ & - & $19 \mathrm{u}$ & - & - & $3.9 \mathrm{u}$ & $80 \mathrm{u}$ & - \\
\hline \multirow[t]{2}{*}{28} & - & - & $198 \mathrm{u}$ & - & 14.u & $79 \mathrm{u}$ & $5.3 \mathrm{u}$ & $6.7 \mathrm{u}$ & - & - \\
\hline & - & - & $196 \mathrm{u}$ & - & $20 \mathrm{u}$ & - & $2.1 \mathrm{u}$ & $6.6 \mathrm{u}$ & - & - \\
\hline \multirow[t]{2}{*}{29} & - & - & $188 \mathrm{u}$ & - & $11 \mathrm{u}$ & $12 \mathrm{u}$ & $1.4 \mathrm{u}$ & $4.4 \mathrm{u}$ & - & - \\
\hline & - & - & $260 \mathrm{u}$ & - & $15 \mathrm{u}$ & - & $3.4 \mathrm{u}$ & $8.2 \mathrm{u}$ & - & - \\
\hline \multirow[t]{2}{*}{30} & - & - & $222 \mathrm{u}$ & - & $19 \mathrm{u}$ & - & $1.1 \mathrm{u}$ & $3.8 \mathrm{u}$ & - & - \\
\hline & - & - & $310 \mathrm{u}$ & - & $26 \mathrm{u}$ & - & $2.4 \mathrm{u}$ & $9.9 \mathrm{u}$ & - & - \\
\hline \multirow[t]{2}{*}{31} & - & - & $300 \mathrm{u}$ & - & $24 \mathrm{u}$ & $8.8 \mathrm{u}$ & $2.2 \mathrm{u}$ & $15 \mathrm{u}$ & $72 \mathrm{u}$ & - \\
\hline & .2 & 10 & 443 & 293 & 52 & $<3.0$ & 4.9 & 42 & 74 & $10 \mathrm{e}$ \\
\hline \multirow[t]{2}{*}{32} & - & - & $932 \mathrm{u}$ & - & $102 \mathrm{u}$ & $164 \mathrm{u}$ & $11 \mathrm{u}$ & $58 \mathrm{u}$ & $112 \mathrm{u}$ & - \\
\hline & .6 & 49 & 1,540 & 1,280 & 135 & 229 & 19 & 28 & 391 & $330 \mathrm{e}$ \\
\hline \multirow[t]{2}{*}{33} & - & - & $352 \mathrm{u}$ & - & $29 \mathrm{u}$ & $6.8 \mathrm{u}$ & $2.8 \mathrm{u}$ & $20 \mathrm{u}$ & - & - \\
\hline & .2 & 11 & 463 & 298 & 52 & 3 & 5.0 & 43 & 74 & $10 \mathrm{e}$ \\
\hline \multirow[t]{2}{*}{34} & - & - & $476 \mathrm{u}$ & - & $45 \mathrm{u}$ & $35 \mathrm{u}$ & $4.2 \mathrm{u}$ & $24 \mathrm{u}$ & $63 \mathrm{u}$ & - \\
\hline & .2 & 11 & 485 & 302 & 52 & 3.9 & 5.0 & 41 & 76 & 10 \\
\hline 35 & - & - & $468 \mathrm{u}$ & - & $59 \mathrm{u}$ & - & $6.2 \mathrm{u}$ & $47 \mathrm{u}$ & $76 \mathrm{u}$ & - \\
\hline \multirow[t]{2}{*}{36} & - & - & $466 \mathrm{u}$ & - & $53 \mathrm{u}$ & - & $5.9 \mathrm{u}$ & $39 u$ & $66 \mathrm{u}$ & - \\
\hline & .2 & 14 & 474 & 321 & 52 & 3.9 & 5.4 & 42 & 75 & $10 \mathrm{e}$ \\
\hline \multirow[t]{2}{*}{37} & - & - & $450 \mathrm{u}$ & - & $41 \mathrm{u}$ & $5.5 \mathrm{u}$ & $4.5 \mathrm{u}$ & $34 \mathrm{u}$ & $58 \mathrm{u}$ & - \\
\hline & - & - & $466 \mathrm{u}$ & - & $45 \mathrm{u}$ & - & $4.5 \mathrm{u}$ & $36 \mathrm{u}$ & $63 \mathrm{u}$ & - \\
\hline \multirow[t]{2}{*}{38} & - & - & $336 \mathrm{u}$ & - & $27 \mathrm{u}$ & $18 \mathrm{u}$ & $3.0 \mathrm{u}$ & $14 \mathrm{u}$ & $25 \mathrm{u}$ & - \\
\hline & $.1 \mathrm{e}$ & 11 & 373 & 302 & 36 & 27 & 3.4 & 28 & 67 & - \\
\hline \multirow[t]{2}{*}{39} & - & - & $516 \mathrm{u}$ & - & $50 \mathrm{u}$ & $26 \mathrm{u}$ & $6.2 \mathrm{u}$ & $34 \mathrm{u}$ & $62 \mathrm{u}$ & - \\
\hline & .2 & 12 & 443 & 318 & 53 & $2.3 \mathrm{e}$ & 5.2 & 42 & 77 & $<10$ \\
\hline \multirow[t]{2}{*}{40} & - & - & $512 \mathrm{u}$ & - & $44 \mathrm{u}$ & $30 \mathrm{u}$ & $8.5 \mathrm{u}$ & $42 \mathrm{u}$ & $69 \mathrm{u}$ & - \\
\hline & .2 & 12 & 485 & 317 & 51 & $3 e$ & 5.9 & 46 & 77 & $<10$ \\
\hline \multirow[t]{2}{*}{41} & - & - & $240 \mathrm{u}$ & - & $17 \mathrm{u}$ & $7.4 \mathrm{u}$ & $3.8 \mathrm{u}$ & $12 \mathrm{u}$ & - & - \\
\hline & .2 & 22 & 268 & 232 & 21 & 7.2 & 4.8 & 15 & 7.7 & - \\
\hline \multirow[t]{2}{*}{42} & - & - & $488 \mathrm{u}$ & - & $42 \mathrm{u}$ & - & $7.8 \mathrm{u}$ & $40 \mathrm{u}$ & $69 \mathrm{u}$ & - \\
\hline & .2 & 11 & 483 & 316 & 51 & 4.6 & 6.0 & 46 & 77 & $10 \mathrm{e}$ \\
\hline \multirow[t]{2}{*}{43} & - & - & $1,080 \mathrm{u}$ & - & $55 \mathrm{u}$ & $114 \mathrm{u}$ & $12 \mathrm{u}$ & $227 \mathrm{u}$ & $230 \mathrm{u}$ & - \\
\hline & .3 & 18 & 535 & 315 & 47 & 54 & 8.1 & 66 & 73 & $<10$ \\
\hline \multirow[t]{2}{*}{44} & - & - & $522 \mathrm{u}$ & - & $30 \mathrm{u}$ & $55 \mathrm{u}$ & $11 \mathrm{u}$ & $78 \mathrm{u}$ & $55 \mathrm{u}$ & - \\
\hline & .3 & 12 & 535 & 329 & 52 & 5.9 & 8.2 & 59 & 76 & $10 \mathrm{e}$ \\
\hline \multirow[t]{2}{*}{45} & - & - & $520 \mathrm{u}$ & - & $35 \mathrm{u}$ & $76 \mathrm{u}$ & $9.2 \mathrm{u}$ & $53 \mathrm{u}$ & $47 \mathrm{u}$ & - \\
\hline & - & - & $536 \mathrm{u}$ & - & $39 \mathrm{u}$ & - & $11 \mathrm{u}$ & $59 \mathrm{u}$ & $50 \mathrm{u}$ & - \\
\hline \multirow[t]{2}{*}{46} & - & - & $622 \mathrm{u}$ & - & $41 \mathrm{u}$ & $38 \mathrm{u}$ & $14 \mathrm{u}$ & $86 \mathrm{u}$ & $64 \mathrm{u}$ & - \\
\hline & .2 & 12 & 525 & 332 & 52 & 6.6 & 8.2 & 58 & 77 & $<10$ \\
\hline 47 & - & - & $718 \mathrm{u}$ & - & $46 \mathrm{u}$ & $46 u$ & $13 \mathrm{u}$ & $82 \mathrm{u}$ & - & - \\
\hline & - & - & $782 \mathrm{u}$ & - & $61 \mathrm{u}$ & - & $15 \mathrm{u}$ & $110 \mathrm{u}$ & $148 \mathrm{u}$ & - \\
\hline 48 & - & - & $628 \mathrm{u}$ & - & $42 \mathrm{u}$ & $49 \mathrm{u}$ & $15 \mathrm{u}$ & $91 \mathrm{u}$ & - & - \\
\hline & .4 & 26 & 484 & 276 & 33 & 23 & 10 & 64 & 38 & - \\
\hline 49 & - & - & $438 \mathrm{u}$ & - & $39 u$ & $66 \mathrm{u}$ & $13 \mathrm{u}$ & $38 \mathrm{u}$ & $24 \mathrm{u}$ & - \\
\hline & - & - & $414 \mathrm{u}$ & - & $46 \mathrm{u}$ & - & $19 \mathrm{u}$ & $44 \mathrm{u}$ & $20 \mathrm{u}$ & - \\
\hline
\end{tabular}


Table 9. Results of chemical analyses for water samples collected from selected sites on the Bear River and its tributaries, March and July-August 2001-Continued

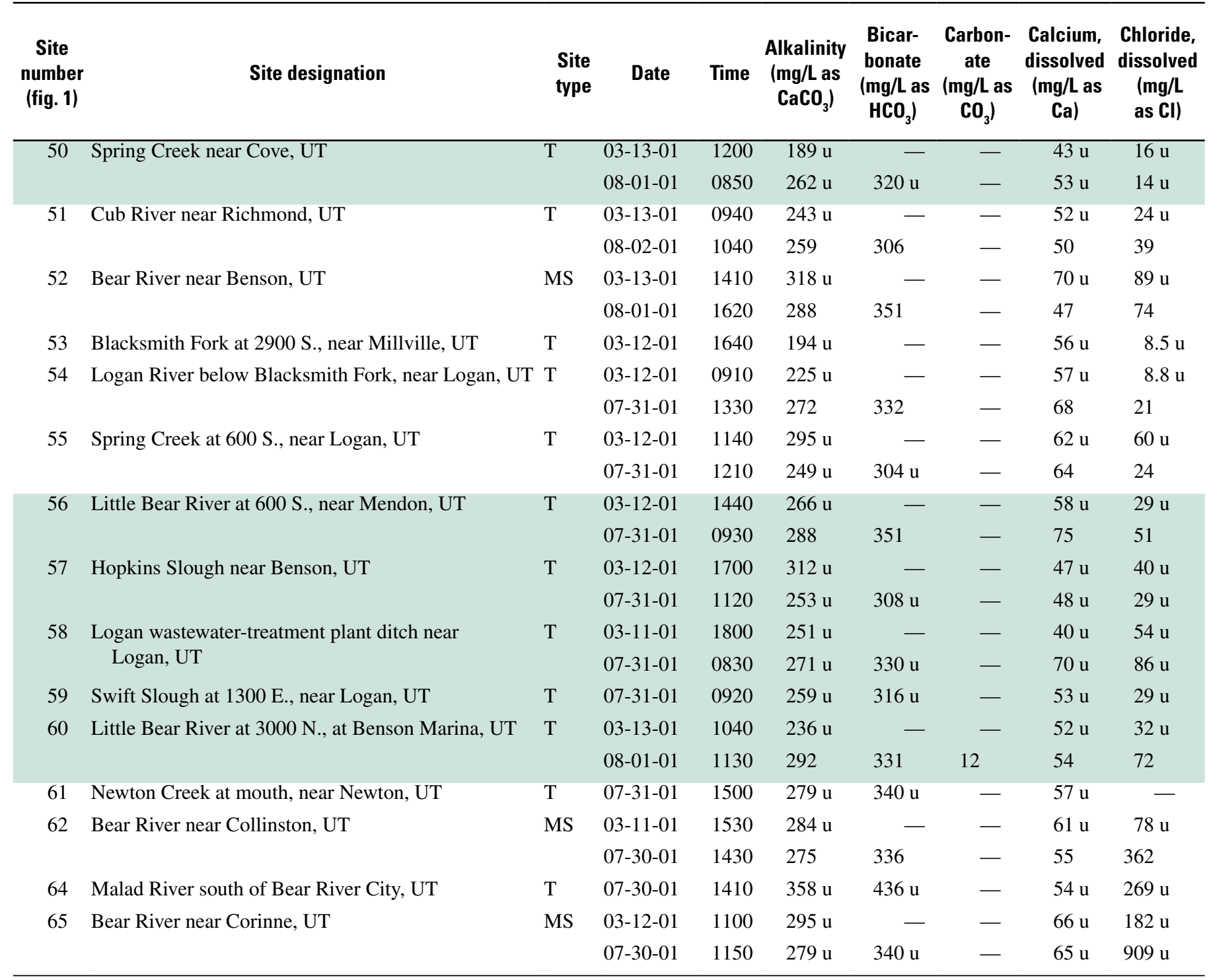

${ }^{1}$ Bear Lake Outlet Canal considered main-stem site because Bear River is diverted from main channel upstream from confluence of outlet canal with main channel. 
Table 9. Results of chemical analyses for water samples collected from selected sites on the Bear River and its tributaries, March and July-August 2001-Continued

\begin{tabular}{|c|c|c|c|c|c|c|c|c|c|c|}
\hline $\begin{array}{c}\text { Site } \\
\text { number } \\
\text { (fig. 1) }\end{array}$ & $\begin{array}{c}\text { Fluoride, } \\
\text { dissolved } \\
\text { (mg/L } \\
\text { as F) }\end{array}$ & $\begin{array}{c}\text { Silica, } \\
\text { dissolved } \\
(\mathrm{mg} / \mathrm{L} \text { as } \\
\left.\mathrm{SiO}_{2}\right)\end{array}$ & $\begin{array}{c}\text { Solids, } \\
\text { residue at } \\
180^{\circ} \mathrm{C} \\
\text { dissolved } \\
(\mathrm{mg} / \mathrm{L})\end{array}$ & $\begin{array}{c}\text { Hardness, } \\
\text { total } \\
(\mathrm{mg} / \mathrm{L} \text { as } \\
\left.\mathrm{CaCO}_{3}\right)\end{array}$ & $\begin{array}{l}\text { Magnesium, } \\
\text { dissolved } \\
\text { (mg/L as } \mathrm{Mg} \text { ) }\end{array}$ & $\begin{array}{c}\text { Manganese, } \\
\text { dissolved } \\
(\mu \mathrm{g} / \mathrm{L} \text { as } \mathrm{Mn})\end{array}$ & $\begin{array}{c}\text { Potassium, } \\
\text { dissolved } \\
\text { (mg/L as K) }\end{array}$ & $\begin{array}{l}\text { Sodium, } \\
\text { dissolved } \\
\text { (mg/L as } \\
\mathrm{Na})\end{array}$ & $\begin{array}{c}\text { Sulfate, } \\
\text { dissolved } \\
\text { (mg/L as } \\
\left.\mathrm{SO}_{4}\right)\end{array}$ & $\begin{array}{c}\text { Iron, } \\
\text { dissolved } \\
\text { ( } \mu \mathrm{g} / \mathrm{L} \text { as Fe) }\end{array}$ \\
\hline \multirow[t]{2}{*}{50} & - & - & $254 \mathrm{u}$ & - & $21 \mathrm{u}$ & $38 \mathrm{u}$ & $4.0 \mathrm{u}$ & $15 \mathrm{u}$ & - & - \\
\hline & - & - & $324 \mathrm{u}$ & - & $31 \mathrm{u}$ & - & $4.0 \mathrm{u}$ & $30 \mathrm{u}$ & - & - \\
\hline \multirow[t]{2}{*}{51} & - & - & $324 \mathrm{u}$ & - & $26 \mathrm{u}$ & $55 \mathrm{u}$ & $9.3 \mathrm{u}$ & $28 \mathrm{u}$ & $21 \mathrm{u}$ & - \\
\hline & $.1 \mathrm{e}$ & 9.3 & 363 & 247 & 30 & 25 & 5.6 & 32 & 26 & $<10$ \\
\hline \multirow[t]{2}{*}{52} & - & - & $542 \mathrm{u}$ & - & $39 \mathrm{u}$ & $32 \mathrm{u}$ & $12 \mathrm{u}$ & $71 \mathrm{u}$ & $59 \mathrm{u}$ & - \\
\hline & .3 & 13 & 528 & 331 & 52 & 3.6 & 7.9 & 58 & 78 & $<10$ \\
\hline 53 & - & - & $246 \mathrm{u}$ & - & $23 \mathrm{u}$ & - & - & $5.6 \mathrm{u}$ & - & - \\
\hline \multirow[t]{2}{*}{54} & - & - & $246 \mathrm{u}$ & - & $23 \mathrm{u}$ & $6.7 \mathrm{u}$ & $1.2 \mathrm{u}$ & $6.5 \mathrm{u}$ & - & - \\
\hline & $.1 \mathrm{e}$ & 9.4 & 336 & 289 & 29 & 38 & 3.6 & 13 & 14 & $30 \mathrm{e}$ \\
\hline \multirow[t]{2}{*}{55} & - & - & $494 \mathrm{u}$ & - & $45 \mathrm{u}$ & $45 \mathrm{u}$ & $14 \mathrm{u}$ & $42 \mathrm{u}$ & $49 \mathrm{u}$ & - \\
\hline & .2 & 12 & 387 & 298 & 34 & 19 & 5.4 & 20 & 46 & $10 \mathrm{e}$ \\
\hline \multirow[t]{2}{*}{56} & - & - & $328 \mathrm{u}$ & - & $28 \mathrm{u}$ & $66 \mathrm{u}$ & $7.8 \mathrm{u}$ & $21 \mathrm{u}$ & - & - \\
\hline & .2 & 23 & 418 & 304 & 28 & 26 & 7.5 & 29 & 14 & $10 \mathrm{e}$ \\
\hline \multirow[t]{2}{*}{57} & - & - & $422 \mathrm{u}$ & - & $43 \mathrm{u}$ & $15 \mathrm{u}$ & $11 \mathrm{u}$ & $43 \mathrm{u}$ & - & - \\
\hline & - & - & $346 \mathrm{u}$ & - & $34 \mathrm{u}$ & $24 \mathrm{u}$ & $7.6 \mathrm{u}$ & $35 \mathrm{u}$ & - & - \\
\hline \multirow[t]{2}{*}{58} & - & - & $374 \mathrm{u}$ & - & $24 \mathrm{u}$ & $40 \mathrm{u}$ & $12 \mathrm{u}$ & $58 \mathrm{u}$ & $29 \mathrm{u}$ & - \\
\hline & - & - & $524 \mathrm{u}$ & - & $34 \mathrm{u}$ & $40 \mathrm{u}$ & $11 \mathrm{u}$ & $70 \mathrm{u}$ & $36 \mathrm{u}$ & - \\
\hline 59 & - & - & $356 \mathrm{u}$ & - & $31 \mathrm{u}$ & $7.9 \mathrm{u}$ & $7.7 \mathrm{u}$ & $30 \mathrm{u}$ & $21 \mathrm{u}$ & - \\
\hline \multirow[t]{2}{*}{60} & - & - & $330 \mathrm{u}$ & $244 \mathrm{u}$ & $28 \mathrm{u}$ & $23 \mathrm{u}$ & $6.6 \mathrm{u}$ & $26 \mathrm{u}$ & $24 \mathrm{u}$ & - \\
\hline & .3 & 17 & 518 & 323 & 46 & $<3.0$ & 8.2 & 57 & 61 & $<10$ \\
\hline 61 & - & - & $530 \mathrm{u}$ & - & $55 \mathrm{u}$ & $33 \mathrm{u}$ & $9.0 \mathrm{u}$ & $60 \mathrm{u}$ & $79 \mathrm{u}$ & - \\
\hline \multirow[t]{2}{*}{62} & - & - & $462 \mathrm{u}$ & - & $34 \mathrm{u}$ & $11 \mathrm{u}$ & $9.6 \mathrm{u}$ & $57 \mathrm{u}$ & $42 \mathrm{u}$ & - \\
\hline & .3 & 15 & 980 & 333 & 47 & 4.6 & 13 & 217 & 68 & $10 \mathrm{e}$ \\
\hline 64 & - & - & $1,160 \mathrm{u}$ & - & $60 \mathrm{u}$ & $8.6 \mathrm{u}$ & 26 & $285 \mathrm{u}$ & $118 \mathrm{u}$ & - \\
\hline \multirow[t]{2}{*}{65} & - & - & $672 \mathrm{u}$ & - & $3.1 \mathrm{u}$ & - & $15 \mathrm{u}$ & $132 \mathrm{u}$ & $48 \mathrm{u}$ & - \\
\hline & - & - & $2,540 \mathrm{u}$ & - & $60 \mathrm{u}$ & - & $47 \mathrm{u}$ & $795 \mathrm{u}$ & $96 \mathrm{u}$ & - \\
\hline
\end{tabular}


Table 10. Results of nutrient and sediment analyses for water samples collected from selected sites on the Bear River and its tributaries, March and July-August 2001

[Site designation: UT, Utah; ID, Idaho; WY, Wyoming; Site type: MS, main stem; T, tributary; mg/L, milligrams per liter; NTU, nephelometric turbidity units; $\%$, percent; mm, millimeter; <, less than; >, greater than;--, no data; e, estimated; u, analyzed by Utah Health Laboratory; c, calculated from total $\mathrm{NO}_{2}+\mathrm{NO}_{3}$ concentration (fig. 2)]

\begin{tabular}{|c|c|c|c|c|c|c|c|}
\hline $\begin{array}{c}\text { Site } \\
\text { number } \\
\text { (fig. 1) }\end{array}$ & Site designation & Site type & Date & Time & $\begin{array}{l}\text { Nitrogen, } \\
\text { ammonia, } \\
\text { dissolved } \\
\text { (mg/L as N) }\end{array}$ & $\begin{array}{c}\text { Nitrogen, } \\
\text { ammonia plus } \\
\text { organic } \\
\text { nitrogen, } \\
\text { dissolved } \\
\text { (mg/L as N) }\end{array}$ & $\begin{array}{c}\text { Nitrogen, } \\
\text { ammonia plus } \\
\text { organic } \\
\text { nitrogen, } \\
\text { total } \\
\text { (mg/L as N) }\end{array}$ \\
\hline \multirow[t]{2}{*}{1} & \multirow[t]{2}{*}{ Bear River near Utah-Wyoming Stateline } & \multirow[t]{2}{*}{ MS } & $03-20-01$ & 1030 & $<0.041$ & $<0.1$ & $0.07 \mathrm{e}$ \\
\hline & & & 08-09-01 & 1100 & $<.04$ & .14 & .17 \\
\hline \multirow[t]{2}{*}{2} & \multirow[t]{2}{*}{ Sulphur Creek at mouth, near Evanston, WY } & \multirow[t]{2}{*}{$\mathrm{T}$} & 03-20-01 & 1300 & - & - & - \\
\hline & & & 08-09-01 & 0850 & - & - & - \\
\hline \multirow[t]{2}{*}{3} & \multirow[t]{2}{*}{ Bear River at Evanston, WY } & \multirow[t]{2}{*}{ MS } & 03-21-01 & 0950 & 162 & .56 & .74 \\
\hline & & & 08-09-01 & 0900 & $.024 \mathrm{e}$ & .41 & .47 \\
\hline \multirow[t]{2}{*}{4} & \multirow{2}{*}{ Bear River below Yellow Creek, near Evanston, WY } & \multirow[t]{2}{*}{ MS } & 03-21-01 & 0920 & - & - & - \\
\hline & & & 08-09-01 & 1140 & $.022 \mathrm{e}$ & .44 & .51 \\
\hline \multirow[t]{2}{*}{5} & \multirow[t]{2}{*}{ Bear River above reservoir, near Woodruff, UT } & \multirow[t]{2}{*}{ MS } & 03-20-01 & 1610 & .312 & 1.2 & 1.5 \\
\hline & & & $08-08-01$ & 1430 & $.021 \mathrm{e}$ & .52 & .6 \\
\hline \multirow[t]{2}{*}{6} & \multirow{2}{*}{ Bear River below reservoir, near Woodruff, UT } & \multirow[t]{2}{*}{ MS } & $03-20-01$ & 1000 & .066 & .27 & .33 \\
\hline & & & $08-08-01$ & 1100 & 198 & .89 & 1 \\
\hline 7 & Saleratus Creek near Woodruff, UT & $\mathrm{T}$ & 03-19-01 & 1520 & - & - & - \\
\hline \multirow[t]{2}{*}{8} & \multirow[t]{2}{*}{ Genes (Woodruff) Creek at Woodruff, UT } & \multirow[t]{2}{*}{$\mathrm{T}$} & 03-19-01 & 1640 & - & - & - \\
\hline & & & $08-08-01$ & 1410 & - & - & - \\
\hline \multirow[t]{2}{*}{9} & \multirow[t]{2}{*}{ Big Creek at Highway 89, near Randolph, UT } & $\mathrm{T}$ & 03-19-01 & 1350 & - & - & - \\
\hline & & & $08-07-01$ & 1520 & - & - & - \\
\hline 10 & Bear River at Randolph, UT & MS & 03-19-01 & 1350 & $<.041$ & .28 & .35 \\
\hline & & & $08-08-01$ & 1140 & $.025 \mathrm{e}$ & .15 & .2 \\
\hline 11 & Otter Creek near Randolph, UT & $\mathrm{T}$ & 03-19-01 & 1530 & - & - & - \\
\hline & & & $08-08-01$ & 0930 & - & - & - \\
\hline 12 & Bear River above Bridger Creek, near Leefe, WY & MS & 03-19-01 & 1140 & 167 & .63 & .8 \\
\hline & & & 08-07-01 & 1230 & $.031 \mathrm{e}$ & .33 & .54 \\
\hline 13 & Twin Creek at Highway 89, near Leefe, WY & $\mathrm{T}$ & 03-18-01 & 1450 & - & - & - \\
\hline & & & 08-07-01 & 0950 & - & - & - \\
\hline 14 & Sublette Creek at Highway 30, near Cokeville, WY & $\mathrm{T}$ & 08-07-01 & 0820 & - & - & - \\
\hline 15 & Bear River below Pixley Dam, near Cokeville, WY & MS & 03-18-01 & 1400 & 058 & .35 & .45 \\
\hline & & & $08-06-01$ & 1600 & $.034 \mathrm{e}$ & .36 & .7 \\
\hline 16 & Spring Creek at Cokeville, WY & $\mathrm{T}$ & 03-19-01 & 1020 & $<.041$ & 13 & .23 \\
\hline & & & 08-07-01 & 1540 & $.03 \mathrm{e}$ & 11 & .2 \\
\hline 17 & Smiths Fork at Highway 30, near Cokeville, WY & $\mathrm{T}$ & 03-18-01 & 1300 & $<.041$ & $.1 \mathrm{e}$ & .22 \\
\hline & & & 08-07-01 & 1350 & $.032 \mathrm{e}$ & $.09 \mathrm{e}$ & 16 \\
\hline 18 & Bear River below Smiths Fork, near Cokeville, WY & MS & 03-18-01 & 1000 & $<.041$ & .15 & .25 \\
\hline & & & 08-07-01 & 0940 & $.024 \mathrm{e}$ & .2 & .3 \\
\hline 19 & Bear River at Border, WY & MS & 03-18-01 & 1040 & $<.041$ & .14 & .26 \\
\hline & & & $08-06-01$ & 1410 & $.034 \mathrm{e}$ & 18 & .22 \\
\hline 20 & Thomas Fork at mouth, near Border, WY & $\mathrm{T}$ & 03-17-01 & 1440 & $.025 \mathrm{e}$ & 16 & .24 \\
\hline & & & $08-06-01$ & 1200 & $.023 \mathrm{e}$ & .31 & .65 \\
\hline 21 & Bear River at Harer, ID & MS & 08-06-01 & 1000 & $<.04$ & .23 & .38 \\
\hline 22 & Bear River near Dingle, ID & MS & 03-17-01 & 1150 & $<.041$ & $.1 \mathrm{e}$ & .19 \\
\hline & & & $08-06-01$ & 1000 & - & - & - \\
\hline 23 & Bear Lake at Lifton, near St. Charles, ID & $\mathrm{T}$ & $08-05-01$ & 0930 & $<.04$ & .21 & .26 \\
\hline 24 & Bear Lake Outlet Canal near Montpelier, ID & $\mathrm{MS}^{1}$ & 03-17-01 & 1140 & 144 & 4 & .49 \\
\hline & & & $08-05-01$ & 1400 & $<.04$ & .25 & .44 \\
\hline
\end{tabular}


Table 10. Results of nutrient and sediment analyses for water samples collected from selected sites on the Bear River and its tributaries, March and July-August 2001—Continued

\begin{tabular}{|c|c|c|c|c|c|c|c|c|c|c|}
\hline $\begin{array}{c}\text { Site } \\
\text { number } \\
\text { (fig. 1) }\end{array}$ & $\begin{array}{c}\text { Nitrogen, } \\
\mathrm{NO}_{2} \text { plus } \mathrm{NO}_{{ }^{\prime}} \\
\text { dissolved } \\
\text { (mg/L as N) }\end{array}$ & $\begin{array}{c}\text { Nitrogen, } \\
\mathrm{NO}_{2} \text { plus } \\
\mathrm{NO}_{3^{\prime}} \\
\text { total } \\
\text { (mg/L as N) }\end{array}$ & $\begin{array}{c}\text { Nitrogen, } \\
\text { nitrite, } \\
\text { dissolved } \\
\text { (mg/L as N) }\end{array}$ & $\begin{array}{l}\text { Phosphorus, } \\
\text { dissolved } \\
\text { (mg/L } \\
\text { as P) }\end{array}$ & $\begin{array}{c}\text { Ortho } \\
\text { phosphorus, } \\
\text { dissolved } \\
\text { (mg/L as } \mathrm{P} \text { ) }\end{array}$ & $\begin{array}{l}\text { Phos- } \\
\text { phorus, } \\
\text { total } \\
\text { (mg/L } \\
\text { as P) }\end{array}$ & $\begin{array}{l}\text { Turbidity } \\
\text { (NTU) }\end{array}$ & $\begin{array}{c}\text { Suspended } \\
\text { sediment, } \\
\text { (\% finer than } \\
0.062 \mathrm{~mm} \text { ) }\end{array}$ & $\begin{array}{c}\text { Suspended } \\
\text { sediment } \\
\text { (mg/L) }\end{array}$ & $\begin{array}{c}\text { Total } \\
\text { suspended } \\
\text { solids } \\
\text { (mg/L) }\end{array}$ \\
\hline \multirow[t]{2}{*}{1} & 0.122 & $0.17 \mathrm{u}$ & $<0.006$ & $<0.006$ & $<0.018$ & $<.004$ & 1.1 & - & 3 & $<4 \mathrm{u}$ \\
\hline & .041 e & - & $<.006$ & $<.006$ & $<.02$ & .005 & .8 & 79 & 4 & - \\
\hline \multirow[t]{2}{*}{2} & $.18 \mathrm{c}$ & $.25 \mathrm{u}$ & - & - & - & $.441 \mathrm{u}$ & 32 & - & 77 & $78 \mathrm{u}$ \\
\hline & $<.01 \mathrm{u}$ & - & - & $.02 \mathrm{u}$ & - & $.026 \mathrm{u}$ & 5 & 72 & 8 & $5.3 \mathrm{u}$ \\
\hline \multirow[t]{2}{*}{3} & .116 & $.17 \mathrm{u}$ & $.005 \mathrm{e}$ & .019 & $<.018$ & .072 & 18 & - & 24 & $24 \mathrm{u}$ \\
\hline & $.039 \mathrm{e}$ & - & $<.006$ & $.005 \mathrm{e}$ & $<.02$ & .01 & 1.4 & - & 2 & - \\
\hline \multirow[t]{2}{*}{4} & $.15 \mathrm{c}$ & $.22 \mathrm{u}$ & - & - & - & $.167 \mathrm{u}$ & 47 & - & 48 & $50 \mathrm{u}$ \\
\hline & $.026 \mathrm{e}$ & - & $<.006$ & .025 & $.017 \mathrm{e}$ & .04 & 2.6 & - & 7 & - \\
\hline \multirow[t]{2}{*}{5} & .139 & $.20 \mathrm{u}$ & .009 & .109 & .08 & .273 & 72 & - & 90 & $86 \mathrm{u}$ \\
\hline & $.031 \mathrm{e}$ & - & $<.006$ & .025 & $.014 \mathrm{e}$ & .018 & 1.4 & - & 2 & $<4 \mathrm{u}$ \\
\hline \multirow[t]{2}{*}{6} & .227 & $.29 \mathrm{u}$ & $.003 \mathrm{e}$ & .035 & .025 & .05 & 3.4 & - & 2 & $<4 \mathrm{u}$ \\
\hline & .075 & - & .029 & .153 & .132 & 198 & 15 & - & 15 & $11 \mathrm{u}$ \\
\hline 7 & $.39 \mathrm{c}$ & $.47 \mathrm{u}$ & - & - & - & $.317 \mathrm{u}$ & 7.4 & - & 14 & $12 \mathrm{u}$ \\
\hline \multirow[t]{2}{*}{8} & - & $<.10 \mathrm{u}$ & - & - & - & $.347 \mathrm{u}$ & 2.1 & - & - & $<4 \mathrm{u}$ \\
\hline & $<.01 \mathrm{u}$ & - & - & $<.02 \mathrm{u}$ & - & $<.02 \mathrm{u}$ & 1.8 & 59 & 8 & $5.2 \mathrm{u}$ \\
\hline \multirow[t]{2}{*}{9} & $.06 \mathrm{c}$ & $.13 \mathrm{u}$ & - & - & - & $.073 \mathrm{u}$ & 7.5 & - & 20 & $16 \mathrm{u}$ \\
\hline & $<.01 \mathrm{u}$ & - & - & $.075 \mathrm{u}$ & - & $.098 \mathrm{u}$ & 4.7 & 71 & 11 & $15 \mathrm{u}$ \\
\hline \multirow[t]{2}{*}{10} & .05 & $<.10 \mathrm{u}$ & $.003 \mathrm{e}$ & .009 & $<.018$ & .036 & 5.5 & - & 11 & $8 \mathrm{u}$ \\
\hline & $.026 \mathrm{e}$ & - & $<.006$ & .01 & $<.02$ & .019 & - & 61 & 24 & - \\
\hline \multirow[t]{2}{*}{11} & $.11 \mathrm{c}$ & $.18 \mathrm{u}$ & - & - & - & $.195 \mathrm{u}$ & 35 & - & 318 & 93 u \\
\hline & $<.01 \mathrm{u}$ & - & - & $<.02 \mathrm{u}$ & - & $.033 \mathrm{u}$ & 1.8 & 88 & 26 & $<4 \mathrm{u}$ \\
\hline \multirow[t]{2}{*}{12} & $.044 \mathrm{e}$ & $<.10 \mathrm{u}$ & $.003 \mathrm{e}$ & .014 & $<.018$ & .061 & 14 & - & 20 & $21 \mathrm{u}$ \\
\hline & $.026 \mathrm{e}$ & - & - & $.02 \mathrm{u}$ & $<.02$ & .054 & 7.7 & 97 & 15 & $25 \mathrm{u}$ \\
\hline \multirow[t]{2}{*}{13} & $.07 \mathrm{c}$ & $.14 \mathrm{u}$ & - & - & - & $.068 \mathrm{u}$ & 42 & - & 83 & $50 \mathrm{u}$ \\
\hline & $<.01 \mathrm{u}$ & - & - & $.02 \mathrm{u}$ & - & $<.02 \mathrm{u}$ & 2.3 & 55 & 13 & $<4 \mathrm{u}$ \\
\hline 14 & $<.01 \mathrm{u}$ & - & - & $<.02 \mathrm{u}$ & - & $.023 \mathrm{u}$ & 1.4 & 56 & 9 & $6 \mathrm{u}$ \\
\hline \multirow[t]{2}{*}{15} & $.046 \mathrm{e}$ & $.11 \mathrm{u}$ & $.003 \mathrm{e}$ & .014 & $<.018$ & .041 & 6.6 & - & 5 & $7.2 \mathrm{u}$ \\
\hline & $.024 \mathrm{e}$ & - & $.003 \mathrm{e}$ & .024 & $.012 \mathrm{e}$ & .107 & 36 & 88 & 84 & $19 \mathrm{u}$ \\
\hline \multirow[t]{2}{*}{16} & 195 & $.27 \mathrm{u}$ & $.003 \mathrm{e}$ & .006 & $<.018$ & .031 & 6.6 & - & 27 & $10 \mathrm{u}$ \\
\hline & $.025 \mathrm{e}$ & - & $.003 \mathrm{e}$ & $.006 \mathrm{e}$ & $<.02$ & .018 & 1.7 & - & 12 & $7.2 \mathrm{u}$ \\
\hline \multirow[t]{2}{*}{17} & $.042 \mathrm{e}$ & $<.10 \mathrm{u}$ & $<.006$ & $.004 \mathrm{e}$ & $<.018$ & .028 & 4.5 & - & 17 & $12 \mathrm{u}$ \\
\hline & $.026 \mathrm{e}$ & - & $<.006$ & $.003 \mathrm{e}$ & $<.02$ & .018 & 2.5 & 71 & 9 & $8.4 \mathrm{u}$ \\
\hline \multirow[t]{2}{*}{18} & .075 & $.13 \mathrm{u}$ & $<.006$ & .006 & $<.018$ & .04 & 8.6 & - & 14 & $13 \mathrm{u}$ \\
\hline & .05 & - & $.003 \mathrm{e}$ & .01 & $<.02$ & .031 & 11 & - & 16 & $<4 \mathrm{u}$ \\
\hline \multirow[t]{2}{*}{19} & .073 & $.13 \mathrm{u}$ & $.003 \mathrm{e}$ & .008 & $<.018$ & .032 & 9.7 & - & 61 & $13 \mathrm{u}$ \\
\hline & $.023 \mathrm{e}$ & - & $<.006$ & $.004 \mathrm{e}$ & $<.02$ & .02 & 1.9 & - & 16 & $7.6 \mathrm{u}$ \\
\hline \multirow[t]{2}{*}{20} & 1.17 & $1.27 \mathrm{u}$ & .013 & .004 e & $<.018$ & .054 & 14 & - & 56 & $29 \mathrm{u}$ \\
\hline & $.034 \mathrm{e}$ & - & $.005 \mathrm{e}$ & .007 & $<.02$ & .085 & 38 & 93 & 56 & $51 \mathrm{u}$ \\
\hline 21 & .041 e & - & $<.006$ & .005 e & $<.02$ & .042 & 1.8 & - & 45 & $31 \mathrm{u}$ \\
\hline \multirow[t]{2}{*}{22} & . 164 & - & $.003 \mathrm{e}$ & .004 e & $<.018$ & .022 & 4.8 & - & 16 & - \\
\hline & - & - & - & - & - & - & 3.2 & 84 & 52 & - \\
\hline 23 & $.027 \mathrm{e}$ & - & $<.006$ & $<.006$ & $<.02$ & .014 & 4.4 & 94 & 17 & - \\
\hline \multirow[t]{2}{*}{24} & 207 & $.27 \mathrm{u}$ & $.005 \mathrm{e}$ & .016 & $.009 \mathrm{e}$ & .036 & 3.1 & - & 4 & $<4 \mathrm{u}$ \\
\hline & $.026 \mathrm{e}$ & - & $<.006$ & $.004 \mathrm{e}$ & $<.02$ & .067 & 4.7 & - & 51 & $8 \mathrm{u}$ \\
\hline
\end{tabular}


Table 10. Results of nutrient and sediment analyses for water samples collected from selected sites on the Bear River and its tributaries, March and July-August 2001-Continued

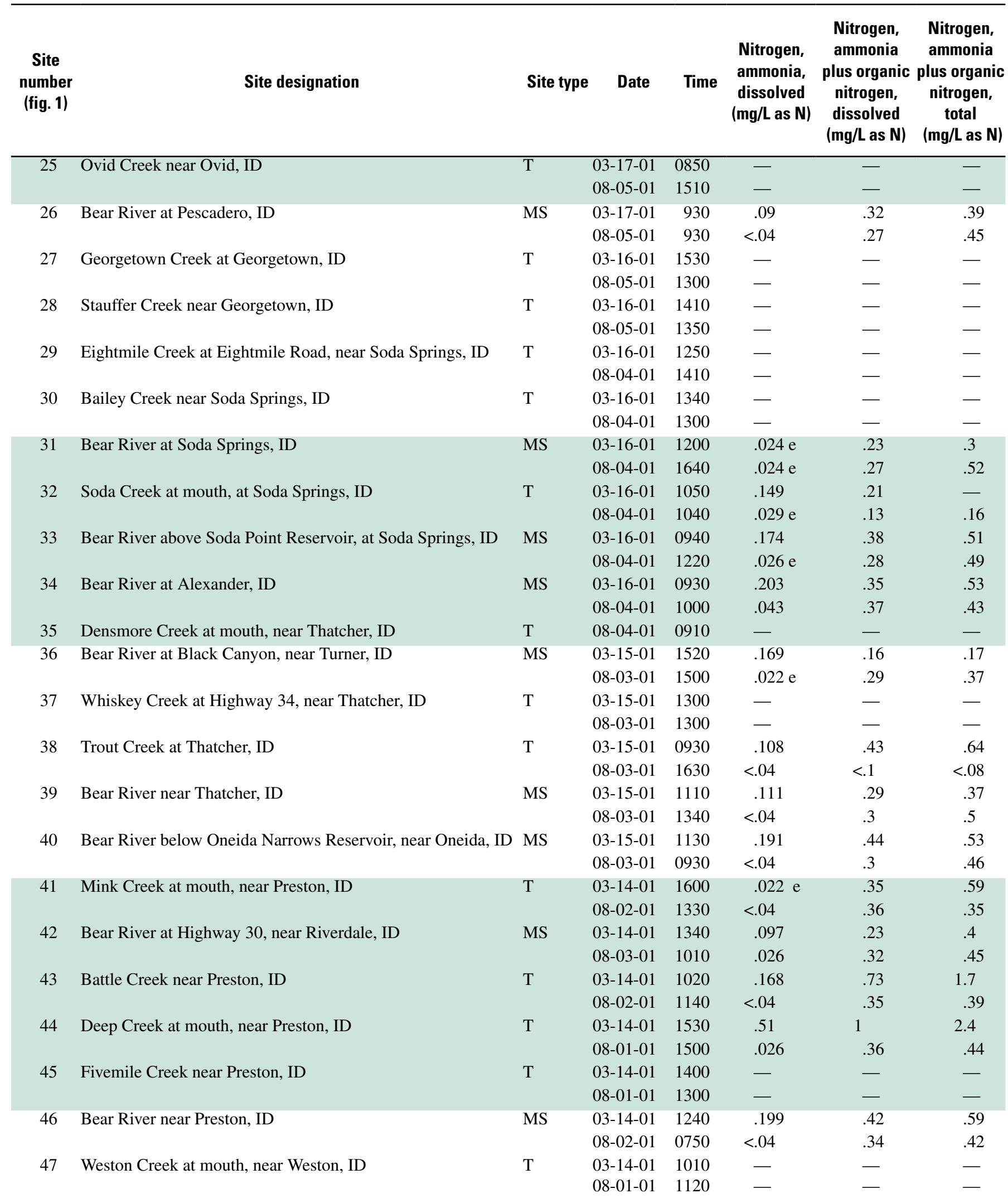


Table 10. Results of nutrient and sediment analyses for water samples collected from selected sites on the Bear River and its tributaries, March and July-August 2001—Continued

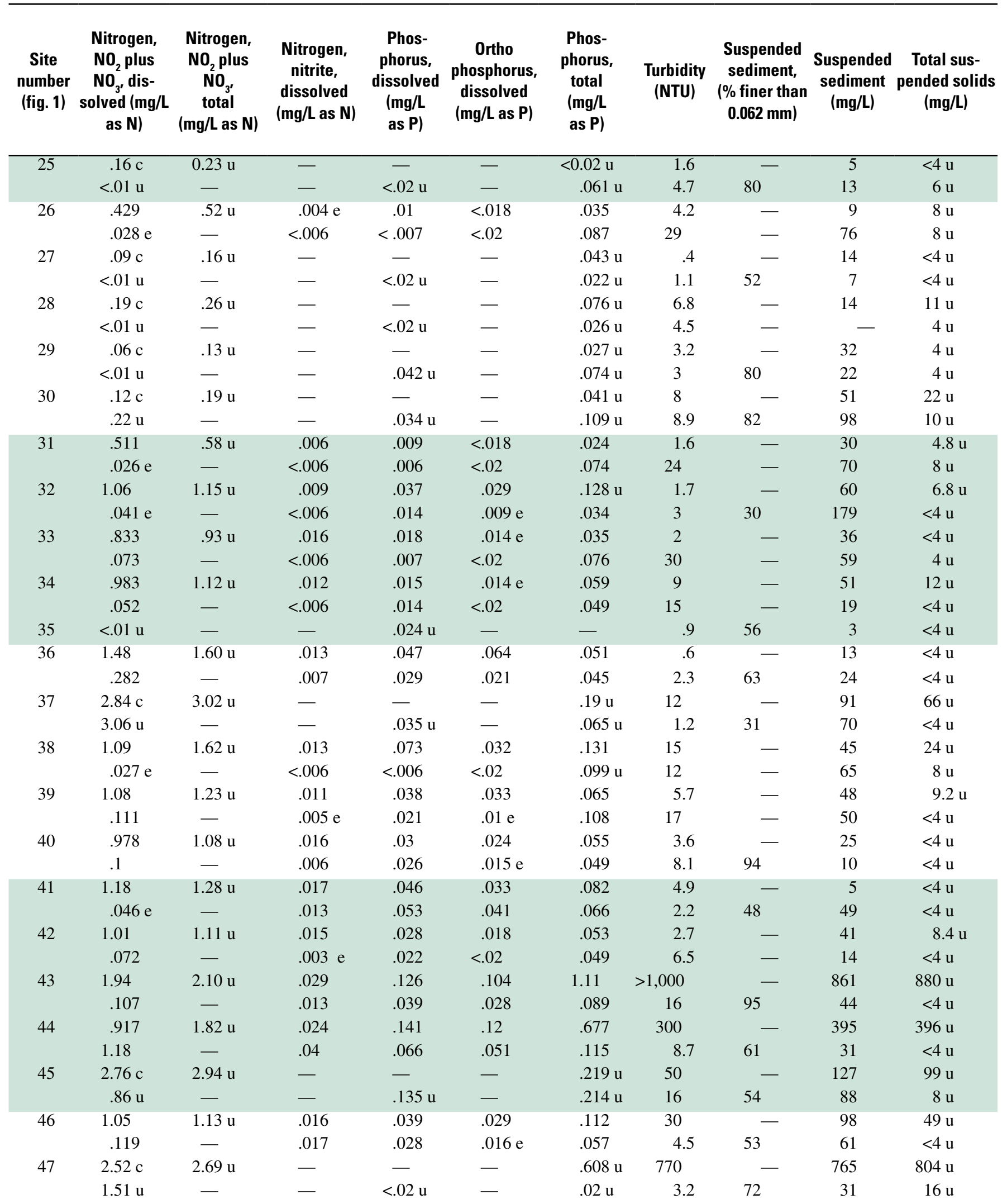


Table 10. Results of nutrient and sediment analyses for water samples collected from selected sites on the Bear River and its tributaries, March and July-August 2001-Continued

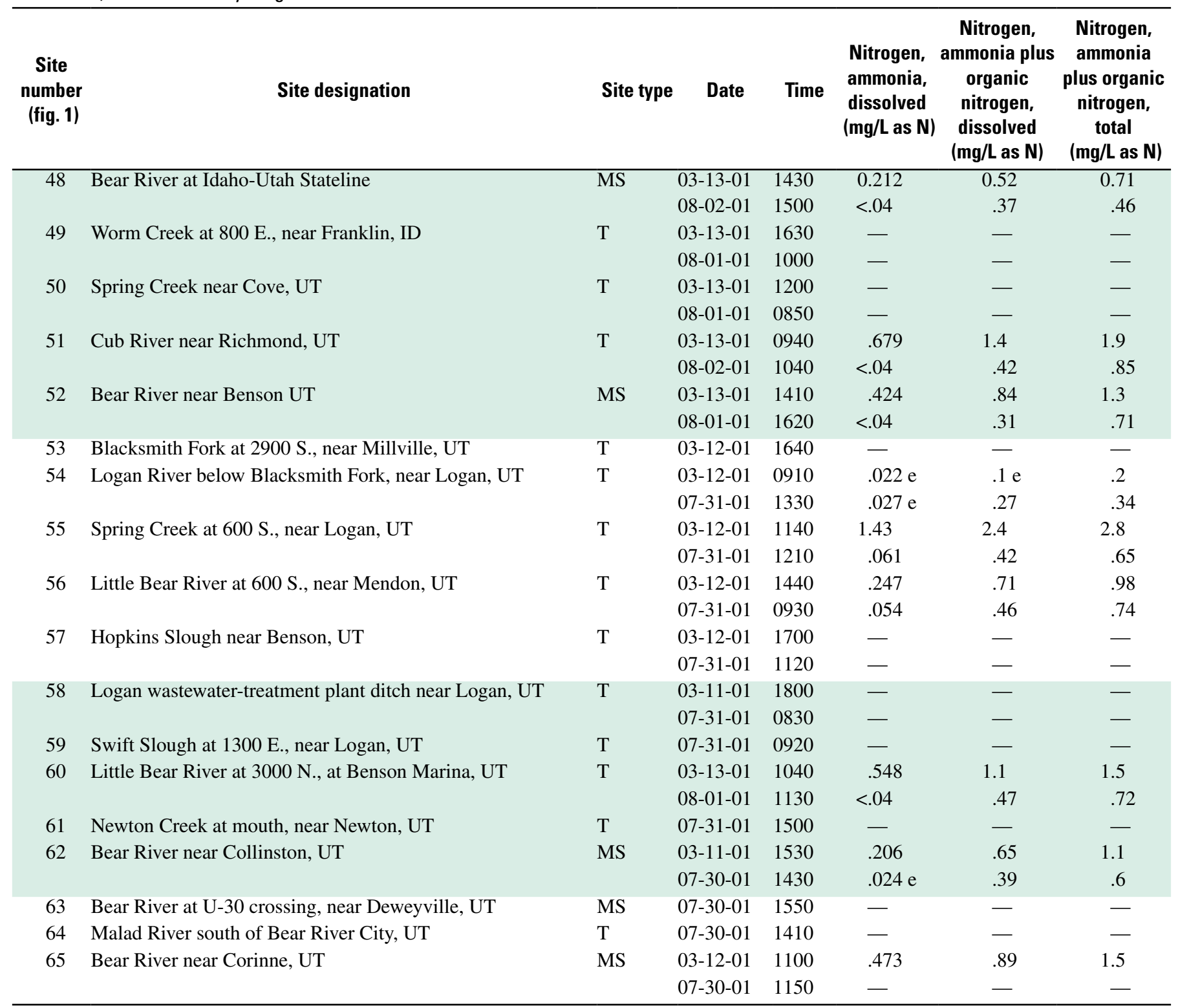

\footnotetext{
${ }^{1}$ Bear Lake Outlet Canal considered main-stem site because Bear River is diverted from main channel upstream from confluence of outlet canal with main channel.
} 
Table 10. Results of nutrient and sediment analyses for water samples collected from selected sites on the Bear River and its tributaries, March and July-August 2001-Continued

\begin{tabular}{|c|c|c|c|c|c|c|c|c|c|c|}
\hline $\begin{array}{c}\text { Site } \\
\text { number } \\
\text { (fig. 1) }\end{array}$ & $\begin{array}{c}\text { Nitrogen, } \\
\mathrm{NO}_{2} \text { plus } \\
\mathrm{NO}_{3^{\prime}} \text { dis- } \\
\text { solved (mg/L } \\
\text { as } \mathrm{N} \text { ) }\end{array}$ & $\begin{array}{c}\text { Nitrogen, } \\
\mathrm{NO}_{2} \text { plus } \\
\mathrm{NO}_{3^{\prime}} \\
\text { total } \\
\text { (mg/L as } \mathrm{N} \text { ) }\end{array}$ & $\begin{array}{c}\text { Nitrogen, } \\
\text { nitrite, } \\
\text { dissolved } \\
\text { (mg/L as } \mathrm{N} \text { ) }\end{array}$ & $\begin{array}{l}\text { Phosphorus, } \\
\text { dissolved } \\
\text { (mg/L } \\
\text { as P) }\end{array}$ & $\begin{array}{c}\text { Ortho } \\
\text { phosphorus, } \\
\text { dissolved } \\
\text { (mg/L as P) }\end{array}$ & $\begin{array}{l}\text { Phos- } \\
\text { phorus, } \\
\text { total } \\
\text { (mg/L } \\
\text { as } \mathrm{P} \text { ) }\end{array}$ & $\begin{array}{c}\text { Turbidity } \\
\text { (NTU) }\end{array}$ & $\begin{array}{l}\text { Suspended } \\
\text { sediment, } \\
\text { (\% finer than } \\
\mathbf{0 . 0 6 2} \mathrm{mm} \text { ) }\end{array}$ & $\begin{array}{c}\text { Suspended } \\
\text { sediment } \\
(\mathrm{mg} / \mathrm{L})\end{array}$ & $\begin{array}{c}\text { Total } \\
\text { suspended } \\
\text { solids } \\
\text { (mg/L) }\end{array}$ \\
\hline \multirow[t]{2}{*}{48} & 1.06 & $1.17 \mathrm{u}$ & 0.018 & 0.054 & 0.043 & 0.143 & 34 & - & 66 & $62 \mathrm{u}$ \\
\hline & .136 & - & .013 & .028 & $.011 \mathrm{e}$ & .074 & 10 & - & 38 & $<4 \mathrm{u}$ \\
\hline \multirow[t]{2}{*}{49} & $4.57 \mathrm{c}$ & $4.82 \mathrm{u}$ & - & - & - & $.593 \mathrm{u}$ & 70 & - & 122 & $111 \mathrm{u}$ \\
\hline & $<.01 \mathrm{u}$ & - & - & $.293 \mathrm{u}$ & - & $.387 \mathrm{u}$ & 29 & - & - & $25 \mathrm{u}$ \\
\hline \multirow[t]{2}{*}{50} & $1.78 \mathrm{c}$ & $1.92 \mathrm{u}$ & - & - & - & $.214 \mathrm{u}$ & 34 & - & 59 & $41 \mathrm{u}$ \\
\hline & $.42 \mathrm{u}$ & - & - & - & - & $.25 \mathrm{u}$ & 6.4 & 77 & 11 & $5.2 \mathrm{u}$ \\
\hline \multirow[t]{2}{*}{51} & 2.06 & $2.28 \mathrm{u}$ & .036 & .216 & .215 & .394 & 43 & - & 63 & $58 \mathrm{u}$ \\
\hline & .998 & - & .043 & .017 & $<.02$ & .142 & 12 & - & 41 & $4 u$ \\
\hline \multirow[t]{2}{*}{52} & 1.51 & $1.63 \mathrm{u}$ & .033 & .12 & .103 & .29 & 71 & - & 96 & $108 \mathrm{u}$ \\
\hline & .129 & - & .009 & .027 & $.01 \mathrm{e}$ & .175 & 69 & - & 141 & $151 \mathrm{u}$ \\
\hline 53 & $.17 \mathrm{c}$ & $.24 \mathrm{u}$ & - & - & - & $<.02 \mathrm{u}$ & 1.3 & - & 13 & $5.6 \mathrm{u}$ \\
\hline \multirow[t]{2}{*}{54} & .326 & $.40 \mathrm{u}$ & $.005 \mathrm{e}$ & .008 & $<.018$ & .023 & .6 & - & 8 & $6 \mathrm{u}$ \\
\hline & .237 & - & .016 & .017 & $<.02$ & .041 & 2.5 & 65 & 53 & $6 \mathrm{u}$ \\
\hline \multirow[t]{2}{*}{55} & 5.28 & $5.35 \mathrm{u}$ & .094 & 1.12 & 1.06 & 1.27 & 15 & - & 30 & $28 \mathrm{u}$ \\
\hline & .595 & - & .021 & .233 & .211 & .345 & 39 & - & 61 & $58 \mathrm{u}$ \\
\hline \multirow[t]{2}{*}{56} & .666 & $.82 \mathrm{u}$ & .015 & .113 & .09 & .174 & 10 & - & 25 & $25 \mathrm{u}$ \\
\hline & .573 & - & .016 & .088 & .067 & .204 & 42 & - & 83 & $61 \mathrm{u}$ \\
\hline \multirow[t]{2}{*}{57} & $2.73 \mathrm{c}$ & $2.91 \mathrm{u}$ & - & - & - & $.235 \mathrm{u}$ & 24 & - & 45 & $43 \mathrm{u}$ \\
\hline & $1.71 \mathrm{u}$ & - & - & $.085 \mathrm{u}$ & - & $.266 \mathrm{u}$ & 65 & 99 & 101 & $94 \mathrm{u}$ \\
\hline \multirow[t]{2}{*}{58} & $.54 \mathrm{c}$ & $.63 \mathrm{u}$ & - & - & - & $2.4 \mathrm{u}$ & 24 & - & 55 & $70 \mathrm{u}$ \\
\hline & $.97 \mathrm{u}$ & - & - & 2.5 & - & $2.3 \mathrm{u}$ & 8.6 & 48 & 93 & $8 \mathrm{u}$ \\
\hline 59 & $<.01 \mathrm{u}$ & - & - & $.049 \mathrm{u}$ & - & $.082 \mathrm{u}$ & 16 & 98 & 31 & $24 \mathrm{u}$ \\
\hline \multirow[t]{2}{*}{60} & 1.06 & $1.14 \mathrm{u}$ & .025 & .314 & .277 & .45 & 41 & - & 48 & $54 \mathrm{u}$ \\
\hline & $.029 \mathrm{e}$ & - & $<.006$ & .12 & .092 & .35 & 96 & - & 111 & $101 \mathrm{u}$ \\
\hline 61 & $.51 \mathrm{u}$ & - & - & $.038 \mathrm{u}$ & - & $.097 \mathrm{u}$ & 20 & - & 40 & $31 \mathrm{u}$ \\
\hline \multirow[t]{2}{*}{62} & 1.76 & $1.04 \mathrm{u}$ & .022 & .077 & .062 & .49 & 45 & - & 44 & $47 \mathrm{u}$ \\
\hline & .082 & - & $<.006$ & .042 & .03 & .137 & 35 & - & 52 & $34 \mathrm{u}$ \\
\hline 63 & - & - & - & - & - & - & 21 & 98 & 46 & - \\
\hline 64 & $1.34 \mathrm{u}$ & - & - & $.185 \mathrm{u}$ & - & $.432 \mathrm{u}$ & 85 & 99 & 148 & $153 \mathrm{u}$ \\
\hline \multirow[t]{2}{*}{65} & .918 & $1.04 \mathrm{u}$ & .026 & .13 & .109 & .289 & 52 & - & 30 & $99 \mathrm{u}$ \\
\hline & $.69 \mathrm{u}$ & - & - & $<.02 \mathrm{u}$ & - & $.287 \mathrm{u}$ & 140 & 99 & 121 & $121 \mathrm{u}$ \\
\hline
\end{tabular}


Table 11. Pesticides detected in water samples collected from selected sites in the Bear River basin, March and July-August 2001 [ $\mu \mathrm{g} / \mathrm{L}$, micrograms per liter; —, no data; e, estimated]

\begin{tabular}{|c|c|c|c|c|c|c|c|}
\hline \multirow{2}{*}{ Pesticide } & \multirow{2}{*}{ Type } & \multirow{2}{*}{$\begin{array}{l}\text { Number of } \\
\text { samples }\end{array}$} & \multirow{2}{*}{$\begin{array}{l}\text { Number of } \\
\text { detections }\end{array}$} & \multirow{2}{*}{$\begin{array}{c}\text { Minimum } \\
\text { reporting } \\
\text { level } \\
\text { ( } \mu \mathrm{g} / \mathrm{L})\end{array}$} & \multirow{2}{*}{$\begin{array}{c}\text { Maximum } \\
\text { concentration } \\
(\mu \mathrm{g} / \mathrm{L})\end{array}$} & \multicolumn{2}{|c|}{ Benchmarks } \\
\hline & & & & & & $\begin{array}{c}\text { Aquatic life } \\
(\mu \mathrm{g} / \mathrm{L})\end{array}$ & $\begin{array}{l}\text { Human health } \\
(\mu \mathrm{g} / \mathrm{L})\end{array}$ \\
\hline $2,4-\mathrm{D}$ & Herbicide & 9 & 3 & 0.21 & $0.03 \mathrm{e}$ & - & 170 \\
\hline Atrazine & Herbicide & 20 & 11 & .007 & $.096 \mathrm{e}$ & ${ }^{2} 1.8$ & 13 \\
\hline Picloram & Herbicide & 9 & 1 & .019 & .09 & 229 & ${ }^{1} 500$ \\
\hline Prometon & Herbicide & 20 & 13 & .015 & $.008 \mathrm{e}$ & - & ${ }^{1} 100$ \\
\hline Tebuthiuron & Herbicide & 20 & 8 & .016 & $.023 \mathrm{e}$ & ${ }^{2} 1.6$ & ${ }^{1} 500$ \\
\hline Azinphos-methyl & Insecticide & 20 & 1 & .050 & $.009 \mathrm{e}$ & ${ }^{3} .01$ & - \\
\hline Deethylatrazine & Degradate & 20 & 9 & .006 & $.015 \mathrm{e}$ & - & - \\
\hline
\end{tabular}

${ }^{1}$ U.S. Environmental Protection Agency, 2004.

${ }^{2}$ Canadian Government Aquatic-Life Guidelines (Canadian Council of Ministers of the Environment, 2001).

${ }^{3}$ U.S. Environmental Protection Agency, 2002. 
Table 12. Results of pesticide analyses of water samples collected from selected sites on the Bear River and its tributaries, March and July-August 2001

[UT, Utah; ID, Idaho; WY, Wyoming; concentration reported in micrograms per liter;<, less than; e, estimated;-, not analyzed]

\begin{tabular}{|c|c|c|c|c|c|c|c|c|c|c|}
\hline Pesticide & Use & Class & $\begin{array}{c}\text { Reporting } \\
\text { level }\end{array}$ & $\begin{array}{c}\text { Bear River } \\
\text { at } \\
\text { Evanston, } \\
\text { WY } \\
\text { (site 3) }\end{array}$ & $\begin{array}{c}\text { Bear River } \\
\text { at } \\
\text { Evanston, } \\
\text { WY } \\
\text { (site 3) }\end{array}$ & $\begin{array}{c}\text { Bear River } \\
\text { below } \\
\text { Yellow Creek, } \\
\text { near Evan- } \\
\text { ston, WY } \\
\text { (site 4) }\end{array}$ & $\begin{array}{c}\text { Bear River } \\
\text { below } \\
\text { Reservoir, } \\
\text { near Wood- } \\
\text { ruff, UT } \\
\text { (site 6) } \\
\end{array}$ & $\begin{array}{c}\text { Bear River } \\
\text { below } \\
\text { Smiths Fork, } \\
\text { near } \\
\text { Cokeville, } \\
\text { WY } \\
\text { (site 18) } \\
\end{array}$ & $\begin{array}{c}\text { Bear River } \\
\text { below } \\
\text { Smiths Fork, } \\
\text { near } \\
\text { Cokeville, } \\
\text { WY } \\
\text { (site 18) } \\
\end{array}$ & $\begin{array}{c}\text { Bear River } \\
\text { at } \\
\text { Harer, ID } \\
\text { (site 21) }\end{array}$ \\
\hline & & & & 03-21-01 & 08-09-01 & 08-09-01 & 08-08-01 & 03-18-01 & 08-07-01 & 08-06-01 \\
\hline 2,6-Diethylaniline & Degradate & aniline & 0.002 & $<.002$ & $<0.002$ & $<0.002$ & $<0.002$ & $<0.002$ & $<0.002$ & $<.002$ \\
\hline Acetochlor & Herbicide & acetanilide & .004 & $<.004$ & $<.004$ & $<.004$ & $<.004$ & $<.004$ & $<.004$ & $<.004$ \\
\hline Atrazine & Herbicide & triazine & .007 & $<.007$ & $<.007$ & $<.007$ & $<.007$ & $<.007$ & $<.007$ & $<.007$ \\
\hline Azinphos-methyl & Insecticide & organothiophosphate & .050 & $<.05$ & $<.05$ & $<.05$ & $<.05$ & $<.050$ & $<.050$ & $<.05$ \\
\hline Benfluralin & Herbicide & dinitroaniline & .010 & $<.01$ & $<.01$ & $<.01$ & $<.01$ & $<.010$ & $<.010$ & $<.01$ \\
\hline Butylate & Herbicide & thiocarbamate & .002 & $<.002$ & $<.002$ & $<.002$ & $<.002$ & $<.002$ & $<.002$ & $<.002$ \\
\hline Carbaryl & Insecticide & carbamate & .041 & $<.041$ & $<.041$ & $<.041$ & $<.041$ & $<.041$ & $<.041$ & $<.041$ \\
\hline Carbofuran & Insecticide & carbamate & .020 & $<.02$ & $<.02$ & $<.02$ & $<.02$ & $<.020$ & $<.020$ & $<.02$ \\
\hline Diazinon & Insecticide & organothiophosphate & .005 & $<.005$ & $<.005$ & $<.005$ & $<.005$ & $<.005$ & $<.005$ & $<.005$ \\
\hline Dieldrin & Insecticide & organochlorine & .005 & $<.005$ & $<.005$ & $<.005$ & $<.005$ & $<.005$ & $<.005$ & $<.005$ \\
\hline Disulfoton & Insecticide & organothiophosphate & .021 & $<.021$ & $<.021$ & $<.021$ & $<.021$ & $<.021$ & $<.021$ & $<.021$ \\
\hline EPTC & Herbicide & thiocarbamate & .002 & $<.002$ & $<.002$ & $<.002$ & $<.002$ & $<.002$ & $<.002$ & $<.002$ \\
\hline Ethalfluralin & Herbicide & dinitroaniline & .009 & $<.009$ & $<.009$ & $<.009$ & $<.009$ & $<.009$ & $<.009$ & $<.009$ \\
\hline Ethoprop & Insecticide & organothiophosphate & .005 & $<.005$ & $<.005$ & $<.005$ & $<.005$ & $<.005$ & $<.005$ & $<.005$ \\
\hline Fonofos & Insecticide & organothiophosphate & .003 & $<.003$ & $<.003$ & $<.003$ & $<.003$ & $<.003$ & $<.003$ & $<.003$ \\
\hline gamma-HCH & Insecticide & organochlorine & .004 & $<.004$ & $<.004$ & $<.004$ & $<.004$ & $<.004$ & $<.004$ & $<.004$ \\
\hline Linuron & Herbicide & urea & .035 & $<.035$ & $<.035$ & $<.035$ & $<.035$ & $<.035$ & $<.035$ & $<.035$ \\
\hline Malathion & Insecticide & organothiophosphate & .027 & $<.027$ & $<.027$ & $<.027$ & $<.027$ & $<.027$ & ${ }^{1} .006 \mathrm{e}$ & ${ }^{1} .002 \mathrm{e}$ \\
\hline Methyl parathion & Insecticide & organothiophosphate & .006 & $<.006$ & $<.006$ & $<.006$ & $<.006$ & $<.006$ & $<.006$ & $<.006$ \\
\hline Metolachlor & Herbicide & acetanilide & .013 & $<.013$ & $<.013$ & $<.013$ & $<.013$ & $<.013$ & $<.013$ & $<.013$ \\
\hline Prometon & Herbicide & triazine & .015 & $<.015$ & ${ }^{1} .005 \mathrm{e}$ & ${ }^{1} .006 \mathrm{e}$ & $<.015$ & $<.015$ & ${ }^{1} .002 \mathrm{e}$ & ${ }^{1} .002 \mathrm{e}$ \\
\hline Pronamide & Herbicide & amide & .004 & $<.004$ & $<.004$ & $<.004$ & $<.004$ & $<.004$ & $<.004$ & $<.004$ \\
\hline Propachlor & Herbicide & acetanilide & .010 & $<.010$ & $<.010$ & $<.010$ & $<.010$ & $<.010$ & $<.010$ & $<.010$ \\
\hline Propanil & Herbicide & amide & .011 & $<.011$ & $<.011$ & $<.011$ & $<.011$ & $<.011$ & $<.011$ & $<.011$ \\
\hline Propargite & Acaricide & sulfite ester & .023 & $<.023$ & $<.023$ & $<.023$ & $<.023$ & $<.023$ & $<.023$ & $<.023$ \\
\hline Simazine & Herbicide & triazine & .011 & $<.011$ & $<.011$ & $<.011$ & $<.011$ & $<.011$ & $<.011$ & $<.011$ \\
\hline Tebuthiuron & Herbicide & urea & .016 & $<.016$ & $.019 \mathrm{e}$ & $.023 \mathrm{e}$ & $.006 \mathrm{e}$ & $<.016$ & $<.016$ & $<.016$ \\
\hline Terbacil & Herbicide & uracil & .034 & $<.034$ & $<.034$ & $<.034$ & $<.034$ & $<.034$ & $<.034$ & $<.034$ \\
\hline Terbufos & Insecticide & organothiophosphate & .017 & $<.017$ & $<.017$ & $<.017$ & $<.017$ & $<.017$ & $<.017$ & $<.017$ \\
\hline Thiobencarb & Herbicide & thiocarbamate & .005 & $<.005$ & $<.005$ & $<.005$ & $<.005$ & $<.005$ & $<.005$ & $<.005$ \\
\hline Triallate & Herbicide & thiocarbamate & .002 & $<.002$ & $<.002$ & $<.002$ & $<.002$ & $<.002$ & $<.002$ & $<.002$ \\
\hline Trifluralin & Herbicide & dinitroaniline & .009 & $<.009$ & $<.009$ & $<.009$ & $<.009$ & $<.009$ & $<.009$ & $<.009$ \\
\hline 2,4-D methyl ester & Herbicide & chlorophenoxy acid ester & .009 & - & $<.009$ & - & - & - & $<.009$ & $<.009$ \\
\hline 2,4-D & Herbicide & chlorophenoxy acid & .021 & - & .03 & - & - & - & $<.02$ & $<.02$ \\
\hline 2,4-DB & Herbicide & chlorophenoxy acid & .016 & - & $<.02$ & - & - & - & $<.008$ & $<.02$ \\
\hline 2-Hydroxyatrazine & Degradate & triazine & .008 & - & $<.008$ & - & - & - & $<.008$ & $<.008$ \\
\hline 3-Hydroxycarbofuran & Degradate & carbamate & .006 & - & $<.01$ & - & - & - & .01 & $<.01$ \\
\hline 3-Ketocarbofuran & Degradate & carbamate & 1.5 & - & $<1.50$ & - & - & - & $<1.50$ & $<1.50$ \\
\hline 3-(4-chlorophenyl)-1- methyl urea & Degradate & phenyl urea & .024 & - & $<.024$ & - & - & - & $<.024$ & $<.024$ \\
\hline
\end{tabular}


Table 12. Results of pesticide analyses of water samples collected from selected sites on the Bear River and its tributaries, March and July-August 2001-Continued

\begin{tabular}{|c|c|c|c|c|c|c|c|c|c|c|c|c|c|}
\hline \multirow{3}{*}{ Pesticide } & \multirow[b]{2}{*}{$\begin{array}{c}\text { Bear River } \\
\text { at } \\
\text { Pescadero, } \\
\text { ID } \\
\text { (site 26) }\end{array}$} & \multirow[b]{2}{*}{$\begin{array}{c}\text { Bear River } \\
\text { at } \\
\text { Pescadero, } \\
\text { ID } \\
\text { (site 26) }\end{array}$} & \multirow[b]{2}{*}{$\begin{array}{l}\text { Bear River } \\
\text { at Soda } \\
\text { Springs, ID } \\
\text { (site 31) }\end{array}$} & \multirow[b]{2}{*}{$\begin{array}{c}\text { Bear River } \\
\text { at } \\
\text { Alexander, } \\
\text { ID } \\
\text { (site 34) }\end{array}$} & \multirow[b]{2}{*}{$\begin{array}{l}\text { Bear River } \\
\text { near } \\
\text { Thatcher, } \\
\text { ID } \\
\text { (site 39) }\end{array}$} & \multirow[b]{2}{*}{$\begin{array}{l}\text { Bear River } \\
\text { at Hwy 30, } \\
\text { near River- } \\
\text { dale, ID } \\
\text { (site 42) }\end{array}$} & \multirow[b]{2}{*}{$\begin{array}{c}\text { Bear River } \\
\text { at ID-UT } \\
\text { Stateline } \\
\text { (site 48) }\end{array}$} & \multirow[b]{2}{*}{$\begin{array}{c}\text { Bear River } \\
\text { at ID-UT } \\
\text { Stateline } \\
\text { (site 48) }\end{array}$} & \multirow[b]{2}{*}{$\begin{array}{l}\text { Cub River } \\
\text { near } \\
\text { Richmond, } \\
\text { UT } \\
\text { (site 51) }\end{array}$} & \multirow[b]{2}{*}{$\begin{array}{l}\text { Cub River } \\
\text { near } \\
\text { Richmond, } \\
\text { UT } \\
\text { (site 51) }\end{array}$} & \multicolumn{3}{|c|}{ Little Bear } \\
\hline & & & & & & & & & & & $\begin{array}{c}\text { Bear River } \\
\text { near } \\
\text { Benson, } \\
\text { UT } \\
\text { (site 52) }\end{array}$ & $\begin{array}{l}\text { River at } \\
3000 \mathrm{~N} ., \\
\text { at Benson } \\
\text { Marina, } \\
\text { UT } \\
\text { (site 60) }\end{array}$ & $\begin{array}{c}\text { Bear River } \\
\text { near } \\
\text { Collinston, } \\
\text { UT } \\
\text { (site 62) } \\
\end{array}$ \\
\hline & 03-17-01 & 08-05-01 & 08-04-01 & 08-04-01 & 08-03-01 & 08-03-01 & 03-13-01 & 08-02-01 & 03-13-01 & 08-02-01 & 08-01-01 & 08-01-01 & $07-30-01$ \\
\hline 2,6-Diethylaniline & $<0.002$ & $<0.002$ & $<0.002$ & $<0.002$ & $<0.002$ & $<0.002$ & $<0.002$ & $<0.002$ & $<0.002$ & $<0.002$ & $<0.002$ & $<0.002$ & $<0.002$ \\
\hline Acetochlor & $<.004$ & $<.004$ & $<.004$ & $<.004$ & $<.004$ & $<.004$ & $<.004$ & $<.004$ & $<.004$ & $<.004$ & $<.004$ & $<.004$ & $<.004$ \\
\hline Alachlor & $<.002$ & $<.002$ & $<.002$ & $<.002$ & $<.002$ & $<.002$ & $<.002$ & $<.002$ & $<.002$ & $<.002$ & $<.002$ & $<.002$ & $<.002$ \\
\hline alpha-HCH & $<.005$ & $<.005$ & $<.005$ & $<.005$ & $<.005$ & $<.005$ & $<.005$ & $<.005$ & $<.005$ & $<.005$ & $<.005$ & $<.005$ & $<.005$ \\
\hline Atrazine & $<.007$ & $.008 \mathrm{e}$ & .008 & .008 & .008 & .008 & $.006 \mathrm{e}$ & $.004 \mathrm{e}$ & .029 & $<.007$ & $.003 \mathrm{e}$ & $.096 \mathrm{e}$ & $.014 \mathrm{e}$ \\
\hline Azinphos-methyl & $<.05$ & $<.05$ & $<.05$ & $<.05$ & $<.05$ & ${ }^{1} .009 \mathrm{e}$ & $<.05$ & $<.05$ & $<.05$ & $<.05$ & $<.05$ & $<.05$ & $<.05$ \\
\hline Benfluralin & $<.01$ & $<.01$ & $<.01$ & $<.01$ & $<.01$ & $<.01$ & $<.01$ & $<.01$ & $<.01$ & $<.01$ & $<.01$ & $<.01$ & $<.01$ \\
\hline Butylate & $<.002$ & $<.002$ & $<.002$ & $<.002$ & $<.002$ & $<.002$ & $<.002$ & $<.002$ & $<.002$ & $<.002$ & $<.002$ & $<.002$ & $<.002$ \\
\hline Carbaryl & $<.041$ & $<.041$ & $<.041$ & $<.041$ & $<.041$ & $<.041$ & $<.041$ & $<.041$ & $<.041$ & $<.041$ & $<.041$ & $<.041$ & $<.041$ \\
\hline Carbofuran & $<.02$ & $<.02$ & $<.02$ & $<.02$ & $<.02$ & $<.02$ & $<.02$ & $<.02$ & $<.02$ & $<.02$ & $<.02$ & $<.02$ & $<.02$ \\
\hline Chlorpyrifos & ${ }^{1} .004 \mathrm{e}$ & $<.005$ & $<.005$ & $<.005$ & $<.005$ & $<.005$ & $<.005$ & $<.005$ & $<.005$ & $<.005$ & $<.005$ & $<.005$ & $<.005$ \\
\hline Cyanazine & $<.018$ & $<.018$ & $<.018$ & $<.018$ & $<.018$ & $<.018$ & $<.018$ & $<.018$ & $<.018$ & $<.018$ & $<.018$ & $<.018$ & $<.018$ \\
\hline Dacthal & $<.003$ & $<.003$ & $<.003$ & $<.003$ & $<.003$ & $<.003$ & $<.003$ & $<.003$ & $<.003$ & $<.003$ & $<.003$ & $<.003$ & $<.003$ \\
\hline Deethylatrazine & $<.006$ & $.001 \mathrm{e}$ & $.001 \mathrm{e}$ & $.002 \mathrm{e}$ & $.002 \mathrm{e}$ & $.002 \mathrm{e}$ & $<.006$ & $<.006$ & $.015 \mathrm{e}$ & $.007 \mathrm{e}$ & $<.006$ & $.009 \mathrm{e}$ & $.005 \mathrm{e}$ \\
\hline Diazinon & $<.005$ & $<.005$ & $<.005$ & $<.005$ & $<.005$ & $<.005$ & $<.005$ & $<.005$ & $<.005$ & $<.005$ & $<.005$ & $<.005$ & $<.005$ \\
\hline Dieldrin & $<.005$ & $<.005$ & $<.005$ & $<.005$ & $<.005$ & $<.005$ & $<.005$ & $<.005$ & $<.005$ & $<.005$ & $<.005$ & $<.005$ & $<.005$ \\
\hline Disulfoton & $<.021$ & $<.021$ & $<.021$ & $<.021$ & $<.021$ & $<.021$ & $<.021$ & $<.021$ & $<.021$ & $<.021$ & $<.021$ & $<.021$ & $<.021$ \\
\hline EPTC & $<.002$ & $<.002$ & $<.002$ & $<.002$ & $<.002$ & $<.002$ & $<.002$ & $<.002$ & $<.002$ & $<.002$ & $<.002$ & $<.002$ & $<.002$ \\
\hline Ethalfluralin & $<.009$ & $<.009$ & $<.009$ & $<.009$ & $<.009$ & $<.009$ & $<.009$ & $<.009$ & $<.009$ & $<.009$ & $<.009$ & $<.009$ & $<.009$ \\
\hline Ethoprop & $<.005$ & $<.005$ & $<.005$ & $<.005$ & $<.005$ & $<.005$ & $<.005$ & $<.005$ & $<.005$ & $<.005$ & $<.005$ & $<.005$ & $<.005$ \\
\hline Fonofos & $<.003$ & $<.003$ & $<.003$ & $<.003$ & $<.003$ & $<.003$ & $<.003$ & $<.003$ & $<.003$ & $<.003$ & $<.003$ & $<.003$ & $<.003$ \\
\hline gamma-HCH & $<.004$ & $<.004$ & $<.004$ & $<.004$ & $<.004$ & $<.004$ & $<.004$ & $<.004$ & $<.004$ & $<.004$ & $<.004$ & $<.004$ & $<.004$ \\
\hline Linuron & $<.035$ & $<.035$ & $<.035$ & $<.035$ & $<.035$ & $<.035$ & $<.035$ & $<.035$ & $<.035$ & $<.035$ & $<.035$ & $<.035$ & $<.035$ \\
\hline Malathion & $<.027$ & ${ }^{1} .004 \mathrm{e}$ & $<.027$ & ${ }^{1} .004 \mathrm{e}$ & ${ }^{1} .004 \mathrm{e}$ & $<.027$ & $<.027$ & $<.027$ & $<.027$ & $<.027$ & $<.027$ & $<.027$ & $<.027$ \\
\hline Methyl parathion & $<.006$ & $<.006$ & $<.006$ & $<.006$ & $<.006$ & $<.006$ & $<.006$ & $<.006$ & $<.006$ & $<.006$ & $<.006$ & $<.006$ & $<.006$ \\
\hline Metolachlor & $<.013$ & $<.013$ & $<.013$ & $<.013$ & $<.013$ & $<.013$ & $<.013$ & $<.013$ & ${ }^{1} .006 \mathrm{e}$ & $<.013$ & $<.013$ & $<.013$ & $<.013$ \\
\hline Metribuzin & $<.006$ & $<.006$ & $<.006$ & $<.006$ & $<.006$ & $<.006$ & $<.006$ & $<.006$ & $<.006$ & $<.006$ & $<.006$ & $<.006$ & $<.006$ \\
\hline Molinate & $<.002$ & $<.002$ & $<.002$ & $<.002$ & $<.002$ & $<.002$ & $<.002$ & $<.002$ & $<.002$ & $<.002$ & $<.002$ & $<.002$ & $<.002$ \\
\hline Napropamide & $<.007$ & $<.007$ & $<.007$ & $<.007$ & $<.007$ & $<.007$ & $<.007$ & $<.007$ & $<.007$ & $<.007$ & $<.007$ & $<.007$ & $<.007$ \\
\hline p,p'-DDE & $<.003$ & $<.003$ & $<.003$ & $<.003$ & $<.003$ & $<.003$ & $<.003$ & $<.003$ & $<.003$ & $<.003$ & $<.003$ & $<.003$ & $<.003$ \\
\hline Parathion & $<.007$ & $<.007$ & $<.007$ & $<.007$ & $<.007$ & $<.007$ & $<.007$ & $<.007$ & $<.007$ & $<.007$ & $<.007$ & $<.007$ & $<.007$ \\
\hline Pebulate & $<.002$ & $<.002$ & $<.002$ & $<.002$ & $<.002$ & $<.002$ & $<.002$ & $<.002$ & $<.002$ & $<.002$ & $<.002$ & $<.002$ & $<.002$ \\
\hline Pendimethalin & $<.01$ & $<.01$ & $<.01$ & $<.01$ & $<.01$ & $<.01$ & $<.01$ & $<.01$ & $<.01$ & $<.01$ & $<.01$ & $<.01$ & $<.01$ \\
\hline cis-Permethrin & $<.006$ & $<.006$ & $<.006$ & $<.006$ & $<.006$ & $<.006$ & $<.006$ & $<.006$ & $<.006$ & $<.006$ & $<.006$ & $<.006$ & $<.006$ \\
\hline Phorate & $<.011$ & $<.011$ & $<.011$ & $<.011$ & $<.011$ & $<.011$ & $<.011$ & $<.011$ & $<.011$ & $<.011$ & $<.011$ & $<.011$ & $<.011$ \\
\hline Prometon & $<.015$ & ${ }^{1} .005 \mathrm{e}$ & ${ }^{1} .006 \mathrm{e}$ & ${ }^{1} .005 \mathrm{e}$ & ${ }^{1} .005 \mathrm{e}$ & ${ }^{1} .005 \mathrm{e}$ & $<.015$ & ${ }^{1} .008 \mathrm{e}$ & $<.015$ & $<.015$ & ${ }^{1} .005 \mathrm{e}$ & ${ }^{1} .007 \mathrm{e}$ & ${ }^{1} .006 \mathrm{e}$ \\
\hline Pronamide & $<.004$ & $<.004$ & $<.004$ & $<.004$ & $<.004$ & $<.004$ & $<.004$ & $<.004$ & $<.004$ & $<.004$ & $<.004$ & $<.004$ & $<.004$ \\
\hline Propachlor & $<.010$ & $<.010$ & $<.010$ & $<.010$ & $<.010$ & $<.010$ & $<.010$ & $<.010$ & $<.010$ & $<.010$ & $<.010$ & $<.010$ & $<.010$ \\
\hline Propanil & $<.011$ & $<.011$ & $<.011$ & $<.011$ & $<.011$ & $<.011$ & $<.011$ & $<.011$ & $<.011$ & $<.011$ & $<.011$ & $<.011$ & $<.011$ \\
\hline Propargite & $<.023$ & $<.023$ & $<.023$ & $<.023$ & $<.023$ & $<.023$ & $<.023$ & $<.023$ & $<.023$ & $<.023$ & $<.023$ & $<.023$ & $<.023$ \\
\hline Simazine & $<.011$ & $<.011$ & $<.011$ & $<.011$ & $<.011$ & $<.011$ & $<.011$ & $<.011$ & $<.011$ & $<.011$ & $<.011$ & $<.011$ & $<.011$ \\
\hline Tebuthiuron & $<.016$ & $.003 \mathrm{e}$ & $.003 \mathrm{e}$ & $.003 \mathrm{e}$ & $.003 \mathrm{e}$ & $.003 \mathrm{e}$ & $<.016$ & $<.016$ & $<.016$ & $<.016$ & $<.016$ & $<.016$ & $<.016$ \\
\hline Terbacil & $<.034$ & $<.034$ & $<.034$ & $<.034$ & $<.034$ & $<.034$ & $<.034$ & $<.034$ & $<.034$ & $<.034$ & $<.034$ & $<.034$ & $<.034$ \\
\hline Terbufos & $<.017$ & $<.017$ & $<.017$ & $<.017$ & $<.017$ & $<.017$ & $<.017$ & $<.017$ & $<.017$ & $<.017$ & $<.017$ & $<.017$ & $<.017$ \\
\hline Thiobencarb & $<.005$ & $<.005$ & $<.005$ & $<.005$ & $<.005$ & $<.005$ & $<.005$ & $<.005$ & $<.005$ & $<.005$ & $<.005$ & $<.005$ & $<.005$ \\
\hline Triallate & $<.002$ & $<.002$ & $<.002$ & $<.002$ & $<.002$ & $<.002$ & $<.002$ & $<.002$ & $<.002$ & $<.002$ & $<.002$ & $<.002$ & $<.002$ \\
\hline Trifluralin & $<.009$ & $<.009$ & $<.009$ & $<.009$ & $<.009$ & $<.009$ & $<.009$ & $<.009$ & $<.009$ & $<.009$ & $<.009$ & $<.009$ & $<.009$ \\
\hline 2,4-D methyl ester & - & $<.009$ & - & - & - & - & - & $<.009$ & - & $<.009$ & $<.009$ & $<.009$ & $<.009$ \\
\hline $2,4-\mathrm{D}$ & - & $<.02$ & - & - & - & - & - & $.01 \mathrm{e}$ & - & $<.02$ & $<.02$ & $<.02$ & $.02 \mathrm{e}$ \\
\hline 2,4-DB & - & $<.02$ & - & - & - & - & - & $<.02$ & - & $<.02$ & $<.02$ & $<.02$ & $<.02$ \\
\hline 2-Hydroxyatrazine & - & $<.008$ & - & - & - & - & - & $<.008$ & - & $<.008$ & $<.008$ & $.031 \mathrm{e}$ & $.009 \mathrm{e}$ \\
\hline 3-Hydroxycarbofuran & - & $<.01$ & - & - & - & - & - & $<.01$ & - & $<.01$ & $<.01$ & $<.01$ & $<.01$ \\
\hline 3-Ketocarbofuran & - & $<1.50$ & - & - & - & - & - & $<1.50$ & - & $<1.50$ & $<1.50$ & $<1.50$ & $<1.50$ \\
\hline 3-(4-chlorophenyl)-1-methyl urea & - & $<.024$ & - & - & - & - & - & $<.024$ & - & $<.024$ & $<.024$ & $<.024$ & $<.024$ \\
\hline
\end{tabular}


Table 12. Results of pesticide analyses of water samples collected from selected sites on the Bear River and its tributaries, March and July-August 2001-Continued

\begin{tabular}{|c|c|c|c|c|c|c|c|c|c|c|}
\hline Pesticide & Use & Class & $\begin{array}{c}\text { Reporting } \\
\text { level }\end{array}$ & $\begin{array}{c}\text { Bear River } \\
\text { at } \\
\text { Evanston, } \\
\text { WY } \\
\text { (site 3) }\end{array}$ & $\begin{array}{c}\text { Bear River } \\
\text { at } \\
\text { Evanston, } \\
\text { WY } \\
\text { (site 3) }\end{array}$ & $\begin{array}{c}\text { Bear River } \\
\text { below } \\
\text { Yellow } \\
\text { Creek, near } \\
\text { Evanston, } \\
\text { WY } \\
\text { (site 4) } \\
\end{array}$ & $\begin{array}{c}\text { Bear River } \\
\text { below } \\
\text { Reservoir, } \\
\text { near Wood- } \\
\text { ruff, UT } \\
\text { (site 6) } \\
\end{array}$ & $\begin{array}{c}\text { Bear River } \\
\text { below } \\
\text { Smiths Fork, } \\
\text { near } \\
\text { Cokeville, } \\
\text { WY } \\
\text { (site 18) } \\
\end{array}$ & $\begin{array}{c}\text { Bear River } \\
\text { below } \\
\text { Smiths Fork, } \\
\text { near } \\
\text { Cokeville, } \\
\text { WY } \\
\text { (site 18) } \\
\end{array}$ & $\begin{array}{c}\text { Bear River } \\
\text { at } \\
\text { Harer, ID } \\
\text { (site 21) }\end{array}$ \\
\hline & & & & 03-21-01 & 08-09-01 & 08-09-01 & 08-08-01 & 03-18-01 & 08-07-01 & 08-06-01 \\
\hline Acifluorfen & Herbicide & benzoic acid & .007 & - & $<.01$ & - & - & - & $<.01$ & $<.01$ \\
\hline Aldicarb sulfone & Degradate & sulfone & .02 & - & $<.02$ & - & - & - & $<.02$ & $<.02$ \\
\hline Aldicarb sulfoxide & Degradate & sulfoxide & .008 & - & $<.01$ & - & - & - & $<.01$ & $<.01$ \\
\hline Aldicarb & Insecticide & carbamate & .04 & - & $<.04$ & - & - & - & $<.04$ & $<.04$ \\
\hline Bendiocarb & Insecticide & carbamate & .025 & - & $<.025$ & - & - & - & $<.025$ & $<.025$ \\
\hline Benomyl & Fungicide & carbamate & .004 & - & $<.004$ & - & - & - & $<.004$ & $<.004$ \\
\hline Bensulfuron-methyl & Herbicide & sulfonylurea & .015 & - & $<.016$ & - & - & - & $<.016$ & $<.016$ \\
\hline Bentazon & Herbicide & $\mathrm{N}$ heterocycle & .011 & - & $<.01$ & - & - & - & $<.01$ & $<.01$ \\
\hline Bromacil & Herbicide & uracil & .033 & - & $<.03$ & - & - & - & $<.03$ & $<.03$ \\
\hline Bromoxynil & Herbicide & phenol & .017 & - & $<.02$ & - & - & - & $<.02$ & $<.02$ \\
\hline Carbaryl & Insecticide & carbamate & .028 & - & $<.03$ & - & - & - & $<.03$ & $<.03$ \\
\hline Carbofuran & Insecticide & carbamate & .006 & - & $<.01$ & - & - & - & $<.01$ & $<.01$ \\
\hline Chloramben methyl ester & Herbicide & chlorobenzoic acid ester & .018 & - & $<.02$ & - & - & - & $<.02$ & $<.02$ \\
\hline Chlorimuron ethyl & Herbicide & sulfonylurea & .01 & - & $<.010$ & - & - & - & $<.010$ & $<.010$ \\
\hline Chlorothalonil & Fungicide & organochlorine & .035 & - & $<.04$ & - & - & - & $<.04$ & $<.04$ \\
\hline Clopyralid & Herbicide & picolinic acid & .013 & - & $<.01$ & - & - & - & $<.01$ & $<.01$ \\
\hline Cycloate & Herbicide & thiocarbamate & .013 & - & $<.01$ & - & - & - & $<.01$ & $<.01$ \\
\hline Dacthal monoacid & Degradate & chlorobenzoic acid ester & .011 & - & $<.01$ & - & - & - & $<.01$ & $<.01$ \\
\hline Deethylatrazine & Degradate & triazine & .028 & - & $<.01$ & - & - & - & $<.01$ & $<.01$ \\
\hline Deisopropylatrazine & Degradate & triazine & .044 & - & $<.04$ & - & - & - & $<.04$ & $<.04$ \\
\hline Dicamba & Herbicide & chlorobenzoic acid & .012 & - & $<.01$ & - & - & - & $<.01$ & $<.01$ \\
\hline Dichlorprop & Herbicide & chlorophenoxy acid & .013 & - & $<.01$ & - & - & - & $<.01$ & $<.01$ \\
\hline Dinoseb & Herbicide & nitrophenol & .012 & - & $<.01$ & - & - & - & $<.01$ & $<.01$ \\
\hline Diphenamid & Herbicide & amide & .026 & - & $<.03$ & - & - & - & $<.03$ & $<.03$ \\
\hline Diuron & Herbicide & urea & .015 & - & $<.01$ & - & - & - & $<.01$ & $<.01$ \\
\hline Fenuron & Herbicide & urea & .031 & - & $<.03$ & - & - & - & $<.03$ & $<.03$ \\
\hline Flumetsulam & Herbicide & sulfonamide & .011 & - & $<.011$ & - & - & - & $<.011$ & $<.011$ \\
\hline Fluometuron & Herbicide & urea & .031 & - & $<.03$ & - & - & - & $<.03$ & $<.03$ \\
\hline Imazaquin & Herbicide & imidazolinone & .016 & - & $<.016$ & - & - & - & $<.016$ & $<.016$ \\
\hline Imazethapyr & Herbicide & imidazolinone & .017 & - & $<.017$ & - & - & - & $<.017$ & $<.017$ \\
\hline Imidacloprid & Insecticide & $\mathrm{N}$ heterocycle & .007 & - & $<.007$ & - & - & - & $<.007$ & $<.007$ \\
\hline Linuron & Herbicide & urea & .014 & - & $<.01$ & - & - & - & $<.01$ & $<.01$ \\
\hline MCPA & Herbicide & chlorophenoxy acid & .016 & - & $<.02$ & - & - & - & $<.02$ & $<.02$ \\
\hline MCPB & Herbicide & chlorophenoxy acid & .015 & - & $<.01$ & - & - & - & $<.01$ & $<.01$ \\
\hline Metalaxyl & Fungicide & amino acid derivative & .02 & - & $<.02$ & - & - & - & $<.02$ & $<.02$ \\
\hline Methiocarb & Insecticide & carbamate & .008 & - & $<.01$ & - & - & - & $<.01$ & $<.01$ \\
\hline Methomyl-oxime & Degradate & oxime & .011 & - & $<.011$ & - & - & - & $<.011$ & $<.011$ \\
\hline Methomyl & Insecticide & carbamate & .004 & - & $<.004$ & - & - & - & $<.004$ & $<.004$ \\
\hline Metsulfuron methyl & Herbicide & sulfonylurea & .025 & - & $<.033$ & - & - & - & $<.025$ & $<.025$ \\
\hline Neburon & Herbicide & urea & .012 & - & $<.01$ & - & - & - & $<.01$ & $<.01$ \\
\hline Nicosulfuron & Herbicide & sulfonylurea & .013 & - & $<.013$ & - & - & - & $<.013$ & $<.013$ \\
\hline Norflurazon & Herbicide & amine & .016 & - & $<.02$ & - & - & - & $<.02$ & $<.02$ \\
\hline Oryzalin & Herbicide & dinitroaniline & .017 & - & $<.02$ & - & - & - & $<.02$ & $<.02$ \\
\hline Oxamyl oxime & Degradate & oxime & .013 & - & $<.013$ & - & - & - & $<.013$ & $<.013$ \\
\hline Oxamyl & Insecticide & carbamate & .012 & - & $<.01$ & - & - & - & $<.01$ & $<.01$ \\
\hline Picloram & Herbicide & amine & .019 & - & $<.02$ & - & - & - & .09 & $<.02$ \\
\hline Propham & Herbicide & carbamate & .01 & - & $<.01$ & - & - & - & $<.01$ & $<.01$ \\
\hline Propiconazole & Fungicide & triazole & .021 & - & $<.021$ & - & - & - & $<.021$ & $<.021$ \\
\hline Propoxur & Insecticide & carbamate & .008 & - & $<.01$ & - & - & - & $<.01$ & $<.01$ \\
\hline Siduron & Herbicide & urea & .016 & - & $<.017$ & - & - & - & $<.017$ & $<.017$ \\
\hline Sulfometuron methyl & Herbicide & sulfonylurea & .009 & - & $<.009$ & - & - & - & $<.009$ & $<.009$ \\
\hline Terbacil & Herbicide & uracil & .01 & - & $<.01$ & - & - & - & $<.01$ & $<.01$ \\
\hline Tribenuron-methyl & Herbicide & sulfonylurea & .009 & - & $<.01$ & - & - & - & $<.01$ & $<.01$ \\
\hline Triclopyr & Herbicide & organochlorine & .022 & - & $<.02$ & - & - & - & $<.02$ & $<.02$ \\
\hline
\end{tabular}

${ }^{1}$ Estimated value below long-term method detection level or one-half laboratory reporting level. 
Table 12. Results of pesticide analyses of water samples collected from selected sites on the Bear River and its tributaries, March and July-August 2001-Continued

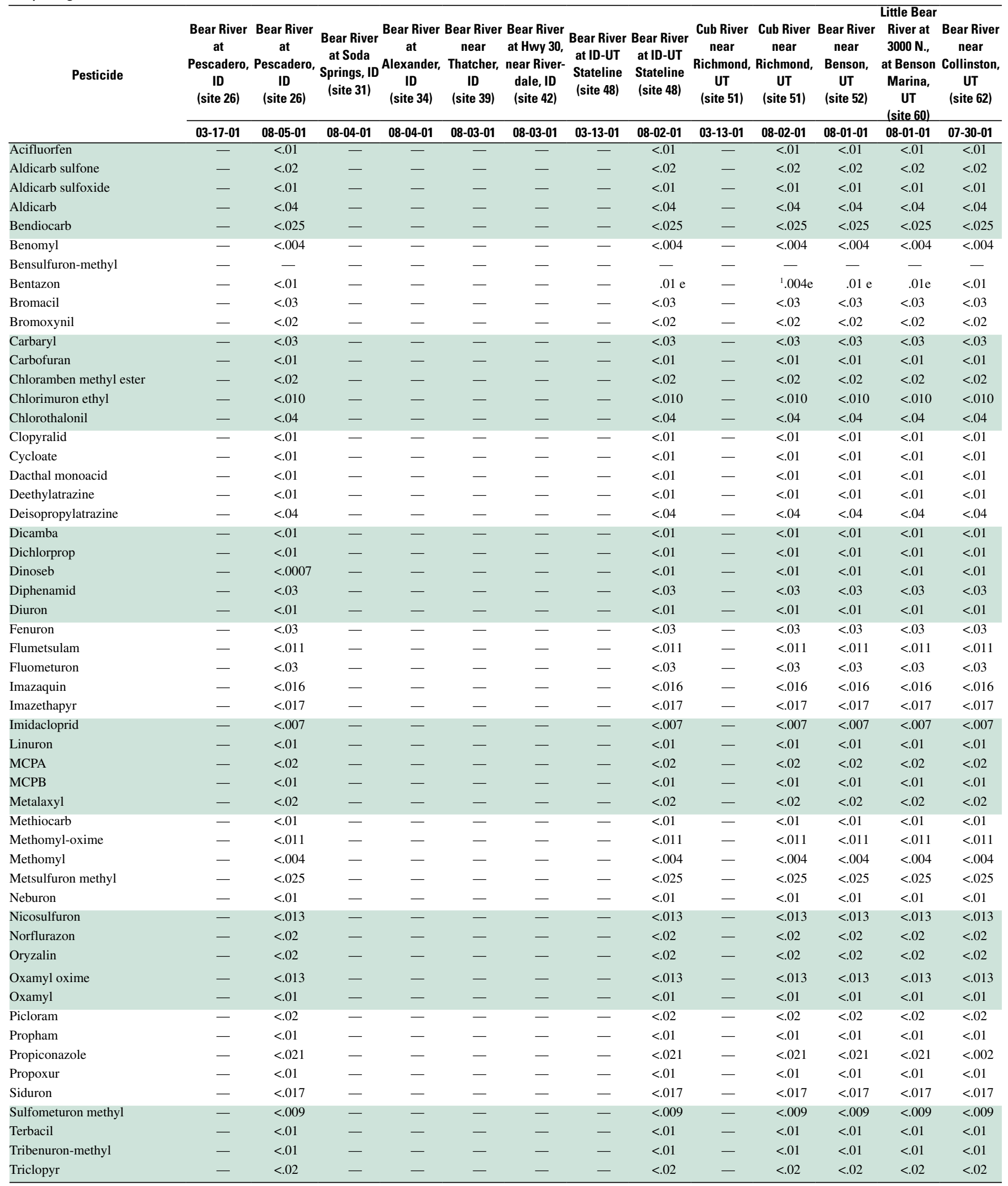


Table 13. Concentration of chlorophyll a in periphyton (algae) samples collected from selected sites in the Bear River basin, August 2001

[Site designation: UT, Utah; WY, Wyoming; ID, Idaho]

\begin{tabular}{|c|c|c|c|c|}
\hline $\begin{array}{c}\text { Site } \\
\text { number } \\
\text { (fig. 1) }\end{array}$ & Site designation & Date & Time & $\begin{array}{l}\text { Chlorophyll a } \\
\text { (milligrams per } \\
\text { square meter) }\end{array}$ \\
\hline 1 & Bear River near Utah-Wyoming Stateline & $08 / 20 / 01$ & 1300 & 21 \\
\hline 3 & Bear River at Evanston, WY & $08 / 20 / 01$ & 1630 & 126 \\
\hline 5 & Bear River above reservoir, near Woodruff, UT & $08 / 22 / 01$ & 1000 & 169 \\
\hline 6 & Bear River below reservoir, near Woodruff, UT & $08 / 21 / 01$ & 1130 & 181 \\
\hline 15 & Bear River below Pixley Dam, near Cokeville, WY & $08 / 23 / 01$ & 0900 & 144 \\
\hline 18 & Bear River below Smiths Fork, near Cokeville, WY & $08 / 23 / 01$ & 1300 & 290 \\
\hline 21 & Bear River at Harer, ID & $08 / 22 / 01$ & 1400 & 29 \\
\hline 26 & Bear River at Pescadero, ID & $08 / 13 / 01$ & 1500 & 66 \\
\hline 31 & Bear River at Soda Springs, ID & $08 / 14 / 01$ & 1100 & 44 \\
\hline 34 & Bear River at Alexander, ID & 08/14/01 & 1430 & 75 \\
\hline 40 & Bear River below Oneida Narrows Reservoir, near Oneida, ID & $08 / 15 / 01$ & 1300 & 416 \\
\hline 42 & Bear River at Highway 30, near Riverdale, ID & $08 / 15 / 01$ & 0900 & 122 \\
\hline 48 & Bear River at Idaho-Utah Stateline & 08/16/01 & 0900 & 44 \\
\hline 62 & Bear River near Collinston, UT & 08/16/01 & 1400 & 196 \\
\hline
\end{tabular}




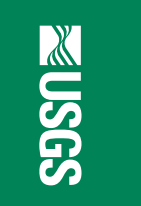

串品

ㄷㅇㅇ 을

겅

일

음

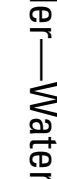

옹

产

空

思

꿍

ए

怘.

으

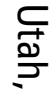

음

을

잉.

끙.

व

ํㅡㄹ

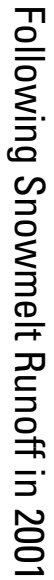

